$1 \mathrm{G} 19$ いて

当院整形外科において手術治療した变形性肘関節症につ

○佐久間隆・倉上親治・福徳修治・土居隆

中野秀昭 - 楫野知道（带広厚生病院整形外科）

肘関節可動域制限や疼痛を主訴とする変形 性肘関節症は鉣業、林業など、上肢を酷使す る重労锄者にしばしば認められる。関節機能 障害や合併する时部管症侯群が日常生活動作 （A D L）上で支障を来す埸合に手術的治潦 がなされる。当科で過去 5 年間に手術治潦を 行った変形性时関節症について検討を加え報 告する。

【症例および方法】

1988年以降、当科において手術的治療を行 った19症例20関節を調查对象とした。症例の 内訳は男性18名、女性 1 名、右 16 例、左 4 例 であり、年踰は $33 \sim 73$ 歳 (平均55.4歳) であ った。これらについて(1)患者の現職または職 業歴、(2)时外傷歴の有無、(3)街前主訴、(4)術 式、(5)術前、術後関節可動域、(6)患者满足度

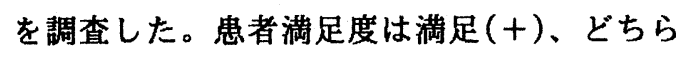
ともいえない(士)、不满足 $(-)$ の 3 段階に分 け、不满足の症例について原因を列挙した。 街後経過稓察期間は 3 力月 3 年 4 力月（平 均 1 年 3 力月)である。

\section{【結 果】}

(1)農業 6 例、酪農業 4 例、運転手 4 例、之 の他 5 例 (工場労徃、店員、坊主、教員、役 員各 1 例）。

(2) 3 例に明らかな外傷の既往があった。 2 例はスポーツ活動での时関節脱臼、1 例は馬 に践られ肘関節を脱白骨折したことがあった。 (3)関節可動域制限17例、疼痛12例、肘部管 症候群12例。

(4) 2 症例に対する再手術を含めた 22 手術の
内訳は、内、外側侵入による関節形成術 16 例 (A 群)、外側侵入 2 例 (B 群)、内側侵入 4 例 (C 群)であり、同時手術として、A群でKing 法 7 例、尺骨神経筋層下移行 5 例、皮下移行 1 例、0sborn法 1 例を行った。B 群は関節形 成術のみであった。C群ではKing法 3 例、筋 層下移行を 1 例に行った。

(5)術前関節可動域は伸展 $-5 \sim-60^{\circ}$ (平均 $-27.3^{\circ}$ ) から屈曲 $75 \sim 130^{\circ}$ (平均 $103.9^{\circ}$ )であ り、術後関節可動域は伸展 $-8 \sim-40^{\circ}$ (平均 $-23.7^{\circ}$ ) から屈曲 $90 \sim 135^{\circ}$ (平均 $119.8^{\circ}$ )であ った。

(6)手術結果に满足と答えた例は14例、不满 足の症例は 3 例であった。不满足の原因とし 乙関節可動域制限、肘関節不安定性、前腕筋 カ低下が原因として挙げられた。

【考 察】

近年、野球时や振動障害が社会的に問題に されるにつれて、変形性肘関節症が注目され るようになった。本症は时関節の外傷後や煩 回な負荷がかかる職業従事者に発症しやすい ことが予想され、主たる症状である関節可動 域制限、関節運動痛、时部管症侯群などが、

A D L 上障害になる場合に手術的治㙩がなさ れる。

今回の調查の結果、患者職業は農業、酪農 業の占める割合が多いことが判明した。これ は当院が農業、酪農地域にあるという、地理 的特殊性を反映しているばかりではなく、本 症がこれらの職業従事者に頻発する疾患であ ることが予測される。本症発生と職業の関係 
については、チェーンソーを使用する林業従

事者に関する詳細な調查が過去になされてい るが、他の職種に関する調査も必要であると 考える。

手術方法は、治療する主应状の原因である 骨䊂、関節鼠の部位、あるいは尺骨神経に対 する操作を加えるか否かなどの要因により異 なるが、我々の症例では関節可動域改善を目 的に両側侵入による骨棘切除（関節形成術） を施行した例が多数を占めた。
手術効果について、関節可動域で見ると、 術前、伸展 $-27.3^{\circ} \sim$ 屈曲 $103.9^{\circ}$ (ROM76. $6^{\circ}$ ) が 術後、伸展 $-23.7^{\circ} \sim$ 屈曲 $119.8^{\circ}$ (ROM96. $1^{\circ}$ ) と 約 $20^{\circ}$ 改善していた。患者满足度では、20関 節中14例 $(70 \%)$ がAＤＬの改善を理由に满足 と解答した。一方、3例(15\%)は先に述べた 関節不安定性などの理由で不满足と解答した が、これらの原因は術中操作、術後後療法に 注意を払うことで、今後防ぐことが可能であ ると考えられた。

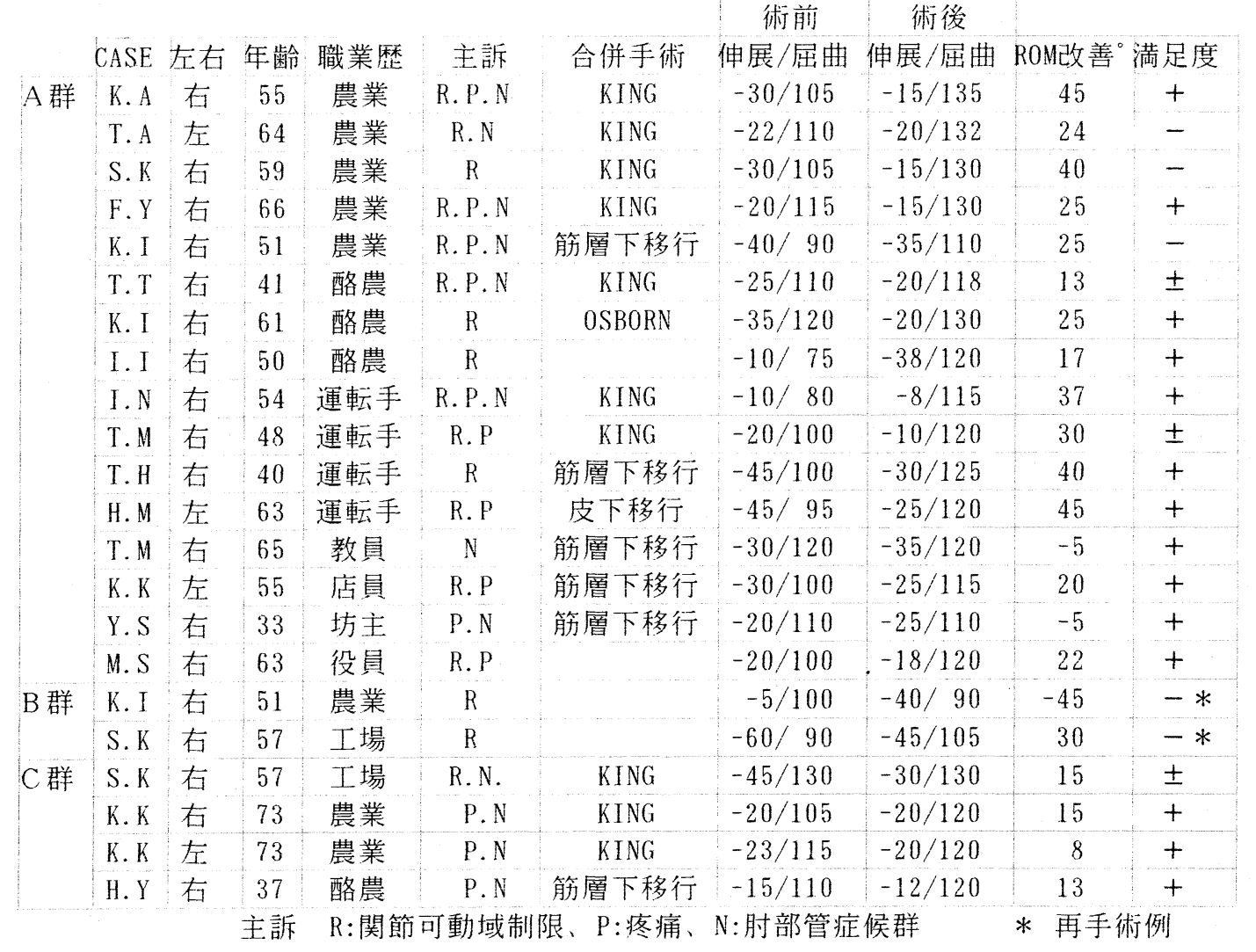


$1 \mathrm{G} 20$ 大腿骨頙部骨折患者の機能的予後の検討

○福徳修治・倉上親治 - 佐久間隆 - 土居隆 中野秀昭 - 栮野知道 (带広厚生病院整形外科)

【はじめに】

近年、人口の高踰化に伴って整形外科領域 でも高齢者の外傷は増加する傾向にある。そ の中でも大腿骨頝部骨折の占める頻度はきわ めて多く、早期離床を目的とした観血的治寮 が積極的に行われている。しかしながら、高 龄者の有する内科的疾患や個々の活動度、体 力的問題から術前に機能的予後を推察するこ とはき才めて困難なことが多い。そこで今回 我々は、過去 3 年間に当科で钼血的治療を行 った60歳以上の大腿骨䅡部骨折患者 138例に 対してアンケートによる機能的予後調查を行 い、これを左右する因子について検討したの で報告する。

\section{【対象】}

平成 2 年 1 月から平成 5 年 4 月までに当科 にて観血的治撚を行った60歳以上の大腿骨頙 部骨折患者 138例について患者およびその家 族にアンケート調查を行い、うち回答のあっ た78例を対象とした。78例中死亡が確珰され たのは11例であったが、生前の状態が詳細に 調查可能であった 3 例については残りの67例 と併せて機能的予後調查を行った。年龄は60 歳から97歳、平均年路78.7歳であり、男19例 女51例、骨折型は内側骨折 22 例、外側骨折 48 例であった。手術法は内側骨折の20例に人工 骨頭置換術、1 例に A O 海綿骨蠂子固定、他 の 1 例と外側骨折の 46 例には compression hip screw を用い固定した。外側骨折中、転 子部の粉研が強いunstable type の 2 例には Ender法を行った。

\section{【方法】}

これらの症例に対して、患者本人には受傷 前後の歩行状態、疼痛および食事介助の有無、 調查時の生活場所について、また家族に対し ては受稘前後の痴呆の程度に関するアンケー ト調查を行った。さらに入院時の全身状態に ついては安達らのリスク基準を用いて段階評 価を行い(Table 1)、年齢および受傷から手 術までの期間と共に機能的予後にあたえる影 䇾について検討した。

\section{【結果】}

歩行能力は (1) 正常 (2) 軽度の跛行 (3) 杖 歩行 (4) 屋内歩行のみ (5) 歩行不能の 5 段階 に分類し、痴呆度は柄沢らの判定基準に準じ て、（1）なし (2) 軽度 (3) 中等度 $(4)$ 高度 (5)非常に高度の 5 段階に分類した。受㑥前 と調査時で比較すると歩行能力では有意に低 下を示し、また痴呆度についても悪化する傾 向にあった(Fig.1，2)。

次に症例を 80 歳未満、80歳以上の 2 群に大 別し、それぞれについて受傷から手術までの 期間で歩行能力の程度を評価すると、80歳以 上で受侮から15日以降に手術が行われた症例 では有意に歩行能力の低下を認めていた(Fig. 3)。また、痴呆度についても同様の結果で、 80歳以上で手術が受稘から15日以降に行われ た症例に悪化を認めた(Fig.4)。

安達らのリスク基準より術前の全身状態を 5 段階に評価するとrisk 3 が 9 例、risk 4 が 44例、risk 5 が17例であった。それぞれにつ いて受傷前、調查時における歩行能力の変化 
をみるとrisk 5 群においては有意に歩行能力 の低下を認めていた(Fig.5)。

\section{【考察】}

大腿骨頝部骨折の術後死亡率は、術後 1 年 から 2 年の間で $5 \%$ から $30 \%$ といわれている。 今回の我々の調查においても短期ながら78例 中11例 $(14 \%) に$ 死亡が確認され、ほぼ同様の 結果であった。さらに死亡例は受傷前の歩行 能力が正常であったもの $(8.5 \%)$ より受傷前 から低下していたもの $(19 \%) の$ 方が多かった。 以上より、受稘前の歩行能力は生命予後を左 右する因子となることが示唆される。

機能的予後に関しては、高齢者ほど受傷時 に身体的、精神的に影響を受けやすいといわ れてきた。我々の調査においても80歳以上で、 手術までに要した期間の長かったものほど歩 行能力、痴呆度は䒼化していた。すなわち、 本疾患の機能的予後は年龄、手術時期および 内科的疾患により左右されると考えられる。 高路者の大腿骨頝部骨折の治療に際しては。 内科医、麻酳医の協力のもと、すみやかに全 身状態の改善をはかり、早期に手術を行うこ とが機能的予後には重要であることが再認識 された。

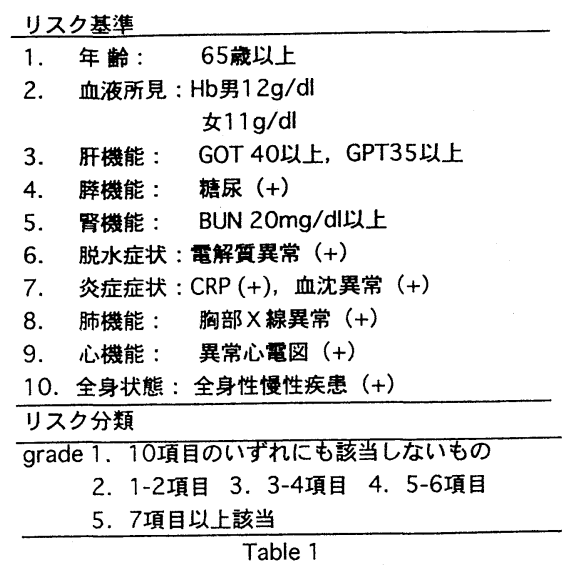
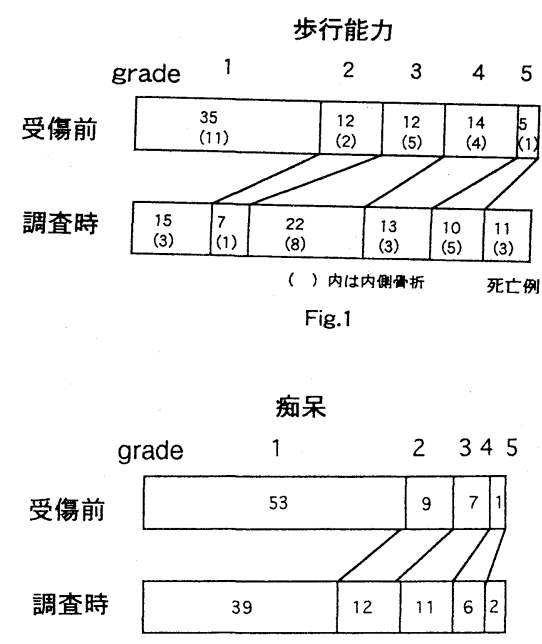

Fig. 2
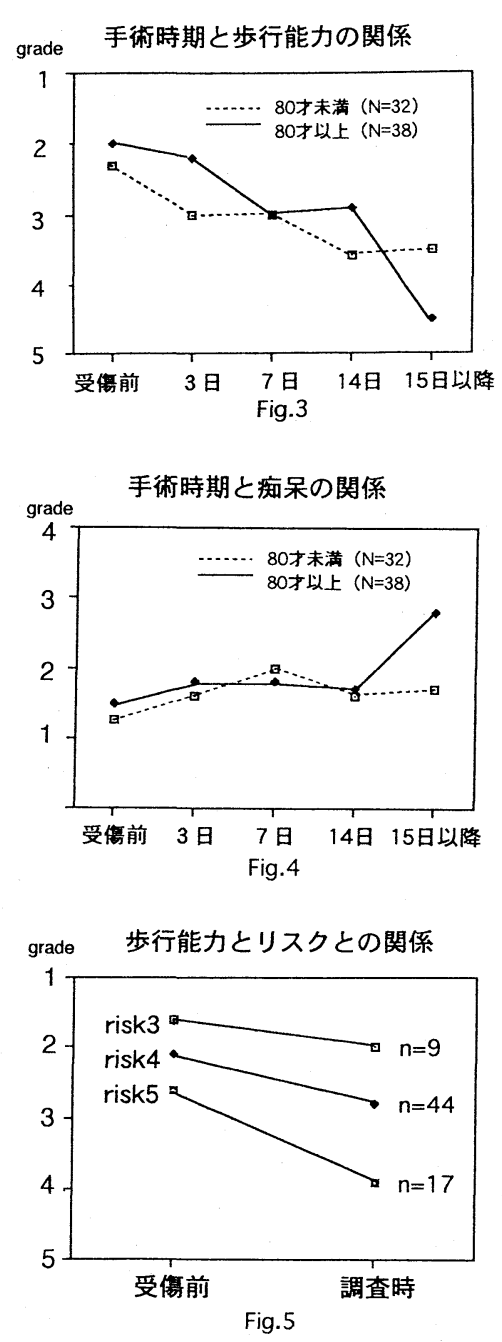


\title{
1G21 高齢者の大腿骨頸部骨折に対する人工骨頭置換術の治療成績
}

\author{
○井上廣司，金井彬，春原久幸，宮正彦 \\ (小諸厚生総合病院 整形外科)
}

近年高秢者の増加に伴って、骨折患者の数 屯著しく増加している。特に農村における高 齿者の増加は都市部よりも顕著で、当然骨折 患者屯多くなっており、社会問題化しつつあ る。今回、私たちは高齢者の骨折の中であ、 特に問題点の多い大腿骨頝部骨折患者につい て、人工骨頭置換術症例の治療成績を調べた。

\section{〈対象〉}

1985 年 3 月から 1992 年 11 月の間に当院で Has ting 人工骨頭置換術を行った 88 例で、 内訳は右 45 例、左 43 例、男 21 例、女 67 例、 手術時年齢は 61 歳から94歳で、平均 77 歳で あった。

\section{〈方 法〉}

主に受傷前の歩行能力之退院時の歩行能力 を評価比較することにより治療成績を検討し た。歩行能力の評価は、I：独歩が可能、 II : 一本杖歩行が可能、III : 二本杖、歩行器、 老人車等が必要、IV : 歩行不能で介助が必要、 と四段階の評価基準を作成しておこなった (表 1 )。

\section{〈結果〉}

受傷時の歩行能力に比して退院時の歩行能 力が向上した例が 1 例、同レベルのものが 20 例、1ランク下がったものが 52 例、2 ランク 以上下がったものが 15 例であった（図 1 )。 最屯多かったのは受傷前は杖なし歩行可能で あったあのが退院時一本杖を使用しているケ
一ス39例であった。これは比較的安定した歩 行をする患者に対しても歩行の安全性から一 本杖を勧めていることにあよっている。また 退院時一本杖歩行以上であった例の中には片 麻痺患者 7 例が含まれていた。しかし、一方 で退院時の歩行能力が 2 ランク以上下がった 例屯15例あり、これらを成績不良例とした。 成績不良と判定したものの中には、アルコー ル依存症、分裂病などの精神疾患を有してい た例が 6 例、高度な老人性痴呆患者が 4 例、 $\mathrm{RA}$ 等のため膝関節、股関節に高度の変形を 有していた例が 2 例、片麻痺を有していた例 が 1 例あり、その他内科的合併症のため転科 となった例、術後DIＣとなり死亡した例が 各1例でかった（表 2 )。いずれの症例にお いても患者が高歯であることと合併症のため に術後早期で十分なリ八ビリテーションが不 可能な症例であった。

\section{〈考察〉}

高榆者の増加とと屯に、多くは骨粗箖症に あとづいて発症する大腿骨䅡部骨折は、高龄 者の割合の多い農村地域では社会問題となり つつある。その一番の問題点は、十分な治療 が何らかの理由で行えない場合、ほとんど寝 たきりあるいは死亡することが必至であるこ とである。その予防のため、早期手術、早期 離床を目ざすのであるが、合併症や患者の意 欲などで十分な治療ができないジレンマをし ばしばおこす。

私たちはその中であできるだけ早期離床が 
得やすいセメント使用の人工骨頭を用い、本 骨折に対する第 1 選択枝としてきた。今回、 その治療成績を調べたが、合併症などで十分 なリハビリテーション訓練が行えなかった症 例は成績がよくなかったが、半数以上は一本 杖で歩行退院しており、一応の評価は与えら れると考える。

表 1. 歩行能力の評価基準

I：独歩可能

II : 一本杖歩行

III : 二本杖、歩行器、老人車等

IV : 車椅子、臥床

表 2. 成績不良例の検討

\begin{tabular}{ll}
\hline 精神疾患 & 6 例 \\
老人性痴呆 & 4 例 \\
高度の関節変形 & 2 例 \\
片麻 㽻 & 1 例 \\
合併症のため転科 & 1 例 \\
死 亡 & 1 例 \\
\hline
\end{tabular}

\section{〈まとめ〉}

1. 大腿骨頚部骨折に対してHasting 人工 骨頭置換を行った 88 例について、受傷前と 退院時の歩行能力の評価を中心に治療成績 を比較検討した。

2. 歩行能力が 2 ランク以上低下した成績不 良例については精神疾患、老人性痴呆など の合併症のため適切な早期リハビリテーシ ョンが不可能なあのであった。

3. Hasting 人工骨頭は高齢者の本骨折の 早期離床、リハビリテーションに有用であ ると考える。

\section{退院時}

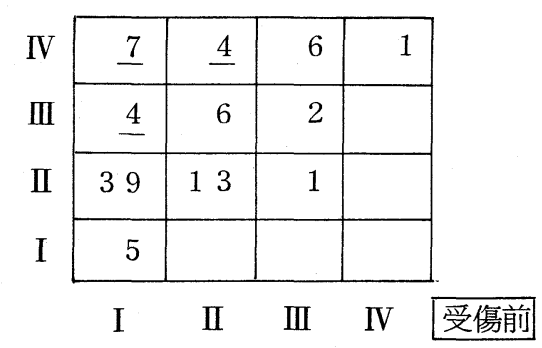

図 1. 受傷前と比較しての退院時の 歩行能力評価 


\section{G22 D E X A 法による骨塩定量の現状と問題点について}

岐阜県厚生連, 総合病院 養老中央病院 整形外科
○平松 哲 西本虎正渡辺数人

同放射線科

近年、高齢化社会の訪れに伴い、骨粗鬆症 がクローズアップされ、その客観的評価とし て骨塩定量屯盛んに行なわれるようになって きた。ととにDEX A 法は現在最も正確度、 精密度も優机、かつ侵襲も少ない方法で、骨 の場では、骨粗鬆症の主な症状発現部位であ る腰椎に対して多く測定が行なわ机、代謝性 骨疾患の早期診断や、薬物療法の効果判定等 亿役立っている。しかしながら、わが国にあ D E X A 装置が普及し 4 年になり、全国であ 数百台設置さ机、実際の臨床に使用されてく るにつ机、その正確性を含めた信頼性につい て疑問視すべき点む多く、発売当初の評価よ りは明らかに劣ってきているものと考えてい る。そこで、D E X A 法を臨床の場で適切に 応用するにあたり、D E X A 法の長所を最大 に生かし、欠点を最小にするために、考慮す べき点を明らかにし、対象に応じた正しい評 価を検討した。

\section{【対象】}

当院にて骨粗鬆症あるいは骨粗鬆症疑いと 診断さ机、D E X A 法にて腰椎正側 2 方向よ り骨塩定量を施行した男 46 例，女 236 例

計 282 例（年齢 18 才 8 8 才、平均 64 才）のデータにつき、以下の項目につき検討 した。

\section{【方法 I】}

前後面像の骨密度（A P - B M D ) と側面 像の骨密度（LA T-B M D ）とを比較し、 相関を求める。その際、年代別、性別でどの

\section{丹羽政美 小野江雅之}

様な特徵があるかも検討する。

$$
\begin{aligned}
& \mathrm{L} 1 \text { - } 4 \text { - AP-BMD亡L 3-LAT-BMD } \\
& \text { L 3-AP-BMD とL 3-LAT-BMD }
\end{aligned}
$$

\section{【方法 II 】}

日常診療に扣いては、A P 像では浜松医大、 川崎医大の、LA T 像では女性のみ大阪弘済 院のまとめたノーマルデータがデータ用紙に くみこまれ、被検者の骨密度が同性、同年齢 の健常日本人平均値之比較でき、患者に対し、 どの程度の治療を行なっていくかの目安にし ているわけであるが、平均值を $100 \%$ とし た場合の初検者の B M D (Zscore) の A P と L A T の間に、実際かなりの相違の見られる ケースにしばしば遭遇する。この矛盾の程度 を調べるにあたり、我々は当院で正、側両方 検査した女性患者について、年代別の A P と L A T のZscoreの較差を調查した。

\section{【結果】}

\begin{tabular}{|c|c|c|c|}
\hline BMD 性別 & 全 & 男性 & 女性 \\
\hline$\left(\begin{array}{l}\mathrm{L} 1-\mathrm{L} 4 \mathrm{AP} \\
\mathrm{L} 3 \mathrm{LAT}\end{array}\right.$ & $\begin{array}{r}0.7820^{\circ} \\
\mathrm{N}=282 \\
\end{array}$ & $\begin{array}{c}0.7668 \\
N=46\end{array}$ & $\begin{array}{r}0.7645 \\
\mathrm{~N}=236\end{array}$ \\
\hline$\left(\begin{array}{ll}\text { L3 } & \text { AP } \\
\text { L3 } & \text { LAT } \\
\end{array}\right.$ & $\begin{array}{r}0.7742 \\
N=271 \\
\end{array}$ & $\begin{array}{r}0.8003 \\
\mathrm{~N}=43\end{array}$ & $\begin{array}{r}0.7522 \\
\mathrm{~N}=228 \\
\end{array}$ \\
\hline
\end{tabular}

表 1 性別 正一側の相関係数

$(\mathbf{P}<0.0001)$

表 2 年代別 女性 L 3 正一側の相関係数

\begin{tabular}{|l|l|l|l|l|}
\hline \begin{tabular}{|l|l|} 
BMD \\
年代
\end{tabular} & $<50$ & $<60$ & $70 \leqq$ & $80 \leqq$ \\
\hline $\begin{array}{l}\text { L3 AP } \\
\text { L3LAT }\end{array}$ & 0.8625 & 0.7831 & 0.6495 & 0.2967 \\
$(P=0.6297)$ \\
\hline
\end{tabular}


表 3 BMD Z Scoreの正一側および年代別比較

\begin{tabular}{|c|c|c|c|}
\hline BMDZ 年代 & 全女性 & $<50$ & $70 \leqq$ \\
\hline$A P \geqq 100$ & 40.5 & 48.0 & 37.3 \\
\hline $\mathrm{LAT} \geqq 100$ & 12.1 & 20.0 & 9.3 \\
\hline $\mathrm{AP}<80$ & 7.8 & 4.0 & 17.9 \\
\hline LAT $<80$ & 54.3 & 56.0 & 65.6 \\
\hline $\mathrm{AP}<70$ & 3.7 & 4.0 & 9.0 \\
\hline LAT $<70$ & 30.5 & 20.0 & 39.1 \\
\hline
\end{tabular}

(\%)

表 4 BMD Z Scoreの正一側および年代別比較 ( ）内の数值は上の段の条件を满たすもののうちの下の段のものの割合

\begin{tabular}{|c|c|c|c|c|}
\hline $\mathrm{BMDZ}$ 年代 & 全女性 & $<50$ & $70 \leqq$ & $60 \leqq$ \\
\hline 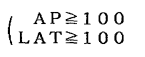 & $\left.\begin{array}{ll}1 & 1.2 \\
(2 & 2.9\end{array}\right)$ & $\begin{array}{l}16.9 \\
(33.3)\end{array}$ & $\left.\begin{array}{r}9.0 \\
(24.0\end{array}\right)$ & 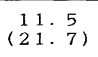 \\
\hline$\left(\begin{array}{l}\mathrm{AP} \geqq 100 \\
\mathrm{LAT}<80\end{array}\right.$ & $\begin{array}{l}16.6 \\
(33.9)\end{array}$ & $\left.\begin{array}{l}12.0 \\
(25.0\end{array}\right)$ & $\begin{array}{c}13.4 \\
(36.0)\end{array}$ & $\begin{array}{r}13.4 \\
(25.3) \\
\end{array}$ \\
\hline$\left(\begin{array}{rl}\mathrm{AP} & \geqslant 100 \\
\mathrm{LAT} & =70\end{array}\right.$ & $\left(\begin{array}{c}5.4 \\
(11.0\end{array}\right)$ & $\left(\begin{array}{ll}0 . & 0 \\
(0 . & 0\end{array}\right)$ & $\left.\begin{array}{r}4.5 \\
(12.0)\end{array}\right)$ & $\left(\begin{array}{l}5.1 \\
(9.6)\end{array}\right.$ \\
\hline$\left(\begin{array}{c}\mathrm{LAT} \geqq 100 \\
\mathrm{AP}<80\end{array}\right.$ & $\left(\begin{array}{cc}0 & 0 \\
0 . & 0\end{array}\right)$ & $\left(\begin{array}{cc}0 . & 0 \\
(0 . & 0\end{array}\right)$ & $\left(\begin{array}{cc}0 . & 0 \\
(0 . & 0\end{array}\right)$ & $\begin{array}{c}0.0 \\
\left(\begin{array}{l}0 . \\
0\end{array}\right)\end{array}$ \\
\hline$\left(\begin{array}{rlll}\mathrm{AP} & \mathrm{P} \geqq 1 & 0 & 0 \\
\mathrm{LAT} & <1 & 0 & 0\end{array}\right.$ & $\begin{array}{c}36.3 \\
(74.3)\end{array}$ & $\begin{array}{r}32.0 \\
(66.7)\end{array}$ & $\left(\begin{array}{c}25.4 \\
(68.0\end{array}\right)$ & $\begin{array}{c}38.2 \\
(72.3)\end{array}$ \\
\hline$\left(\begin{array}{rllll}\mathrm{LAT} & \mathrm{A} & 0 & 0 \\
\mathrm{AP} & <1 & 0 & 0\end{array}\right.$ & $\begin{array}{c}0.9 \\
(7.4)\end{array}$ & $\begin{array}{r}4.0 \\
(20.0)\end{array}$ & 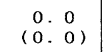 & $\begin{array}{l}0.6 \\
(5.3)\end{array}$ \\
\hline AP $>$ LAT & 91.0 & 96.0 & 93.7 & 89.8 \\
\hline$A P \leqq L A T$ & 9.0 & 4. 0 & 6.3 & 10.2 \\
\hline
\end{tabular}

\section{【考察】}

(\%)

I ）男性と女性では男性の方が加齢に伴なう 骨硬化や、骨棘などの変形性変化が多く、D E X A 法では、海綿骨の骨梁減少を正確飞評 価しにくい。しかしながらての傾向は女性に 扣いてあ少なからず言えるてとであり、男女 とも高齢になると正面像で椎間関節の硬化な どの影響もうけやすく、椎体のosteoporosis が進めば進むほど、正面像で示さ机る骨塩量 全体に対する棘突起、椎弓など後方要素の相 対的割合が大きくなる。したがって、表 2 の でとく正側の相関の良い 50 才未満では正面 D E X A 法のみでの骨塩定量でも診断価值が 高いが、70才以上になると正面のみで診断 するのは危険であり、高齢者であ多少無理し て側臥位での側面像を取るべきと考えられる。
II）実際のところ、骨粗鬆症のある、なしに かかわらず、A P-B M D いるのに L A T - B M D では一S D 以下、あ るいは A P で平均值以上のデータがでている のに側面で平均值以下、ひどいものでは一 $\mathrm{S}$ D以下となっているケースが非常に多い。逆 のパターンはほとんどないといってよい。骨 硬化の多い男性例を除いた例での比較である にあかかわらず、正、側でてれだけ評価にく いちがいが出ている（表 4)。しかしながら、 D E X A を使用している医師ほとんどがての 印象をむっているであろうにもかかわらず、 それをデータで示した報告はみら机ない。疑 問をもたずに両方のデー夕を同時に採用、治 療に利用していることは問題があるのではな いかと思わ机る。I）の結果より、A P のノ ーマルデータとの比較は 50 才未満の例にと どめるのが無難で、純粋に椎体部分を骨塩定 量するL A T 像での評価のほうが特に高齢者 の場合有用である。最近は側臥位にならなく ても、仰臥位で側面像のと机る装置むでてき ており、再現性あかなり良くなることが期待 さ机る。今後のLATのノーマルデータのさ らなる充実を期待したい。

\section{【まとめ】}

1) 当院にて D E X A 法による骨塩定量を行 なった骨粗鬆症患者２８２例のデー夕をもと に、測定法による特長、問題点について検討 した。

2） 50 才未満の比較的若い年齢層の骨密度 評価は、正面像、側面像にあまり隔たりがみ ら机ず、再現性の良い正面像での評価は有用 であるが、高齢にな机ばなるほど正面像のデ 一夕の正確度は低くなるため、高齢者の骨密 度評価は、純粋に椎体部分を定量する側面像 のほうが有用であると考えられた。 
$1 \mathrm{G} 23$ 整形外科手術における医師と患者の関係

栃木県上都賀総合病院

○大井利夫, 松嶋和子, 広田悦子,

福地三千子，星久美子

【目的】医師と患者の関係は、蹦床の場で は橡々な因子が錯綜し、望ましい関係につい て未だ十分な解明がなされているとは言いが たい。特に、患者が手術を要する状態にある ときは一層複雑になる。今回、整形外科の入 院手術患者に対し“患者が手術を決めたとき” の状態などを調查し、医師と患者の関係につ いて考察を加えた。

【方法】平成 4 年 11 月より平成 5 年 3 月 までに当院整形外科にて入院手街を受けた 1 15 名の患者に対し、手術が必要といわれた 時の状態や理解度、決意した時の様子などに つき、病㙌勤務の看護婦が面談による聞き取 り調查を行い、これを項目别に集計した。同 時に患者の背景や病名、手術法等を調べ、侮 病が外傷によるものか否かもチェックした。

【結果】患者の背景は表 1 に示す如くであ る。手術が必要であるといわれた時の場所は、 外来診察室が多く次いで回診中である(図1)。 その時に同席していた医療関係者は看謱婦が 多かったが、同席者なしも $28 \%$ あった。説 明時の患者の状態は $91 \%$ が明瞭であったと

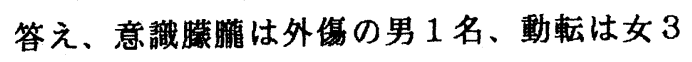
名、痛みで苦しんでいたとしたのは男 2 名女 4名のみである。しかし説明の理解度は、良 く理解できたと答えたものは $41 \%$ に過きな い(図2)。

次に患者が手術を決意した時の様子は、説 明直後が大部分を占めるが非外悔性疾患の女 性に数日後または数回後としたものが見られ た。手術の必要性につき最初の医師以外の説

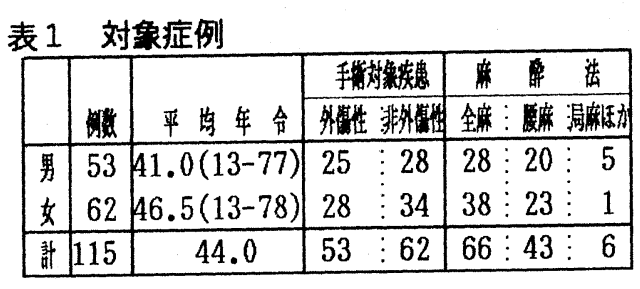

表2手術決意の状態と決定時期

\begin{tabular}{|c|c|c|c|}
\hline & 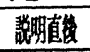 & 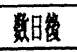 & 基回傮 \\
\hline 自分で淡定 & 89 & 12 & 7 \\
\hline 偝朐され & 1 & 1 & 2 \\
\hline 止光なく & 0 & 1 & 0 \\
\hline 䨞 引 $k$ & 2 & 0 & 0 \\
\hline
\end{tabular}

\section{图1手術説明場所}

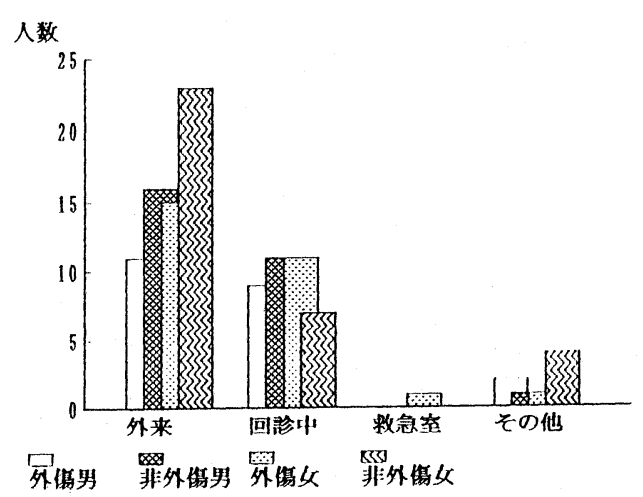

图2 説明の理解度




明者は、なしとする人が多かった。非外侮疾 患患者に対する他の説明者の少ないのが目立 つ(図 3)。手術について相談した人を性別、 配偶者の有無に分けて見ると、既婚の女性は 夫または子供に相談しているものが多い（図 4)。しかし誰が手術を決めたかの問いに対 しては、95\%が自分と答え、その他は 7 名 のみであった。手術決意の状態と決定時期と の関係は表 2 に示す如くである。

手術を受けたあとの感想は $90 \%$ が良かっ たとしているが、非外傷性疾患の女性に満足 していないものが 8 名いた(図 5)。また同じ ような手術を勧められ悩んでいる人がいたら 相談にのり手術を勧めるかに対しても、非外 傷性女性に反対の人が比較的多い。最後に今 後希望することについては $63 \%$ の人がなん らかの希望を述べていた(図6)。

【考察および結語】医師と患者の関係は外 傷時の手術の際では積極一受動の形をとりや すいとされている。しかし今回の調査では外 傷非外傷を問わず、手術が自分で決意したと 答えたものが大部分であった。また $90 \%$ が 満足しているとしている。もっともこの結果 をそのまま全て肯定できないことは、今後へ の希望の多いことが示しているし、理解度の 結果にも見られている。患者は手術に対して も、医師と患者の関係を相互参加とまではい かなくても指導一協調の関係にしたいと希望 しているものと考えられる。このことは術後 の感想が良好としたものの $61 \%$ 今後に希 望を述べていたことからも理解できる。その ためには十分な説明とそれをフォローする人 の必要性が考えられるが、基本的には、個々 の場面における望ましい医師と患者の関係を 確立する事にあり、それに関与する様々な因 子を詳細に解析することが必要であろう。

\section{図3 他の説明者}
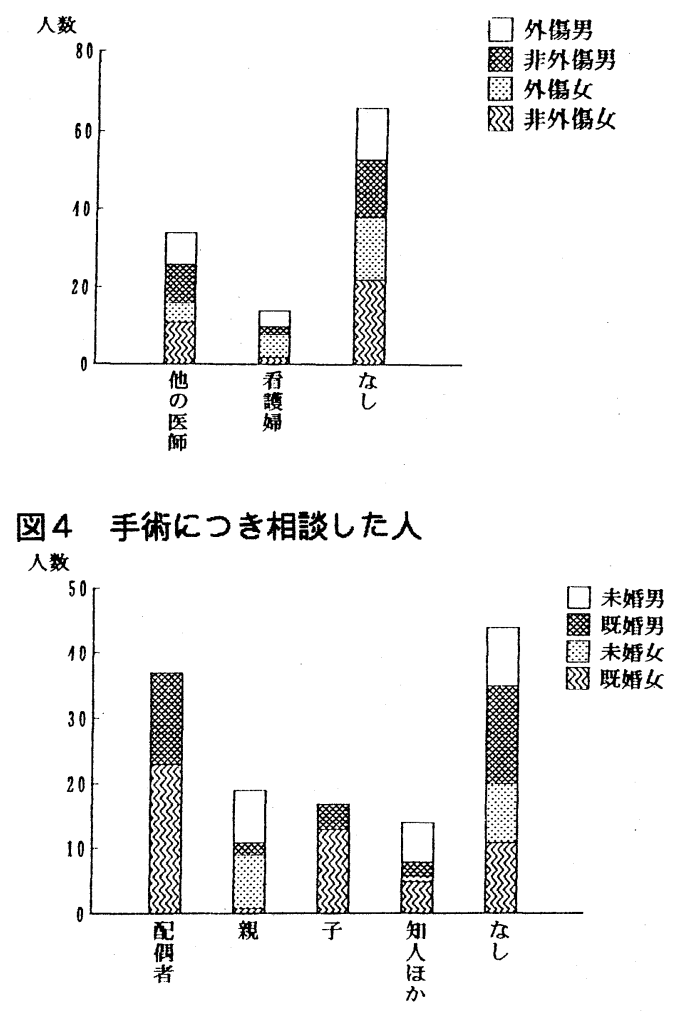

図 5 術後の感想

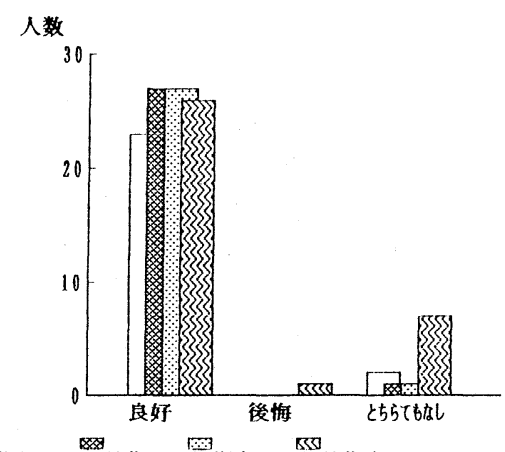

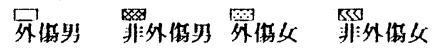

\section{図6今後の希望}

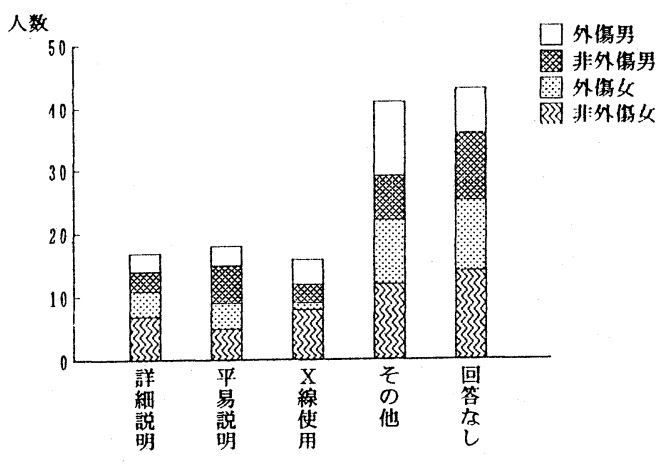




\section{H09人間ドック受診者でのHCV抗体の検討}

\section{JA高知厚生連 \\ 総合農村健康管理センター○中山拓郎 \\ 高知県農協総合病院 内科 安岡 恒}

当センターの人間ドック受診者の内、男性 の約 $10 \%$ に、女性の約 $2 \%$ GOTや GPTの 異常が認められる。平成 4 年度よりドックの 検查項目にHCV抗体の測定を追加して、C型 慢性肝炎の関与を検討したので報告する。
は男性で3.6\%(69名)、女性で5.7\%(68名)であ った。また、同期間のHBs抗原の陽性率は男性 で1.9\%、女性で0.9\%と、HCV抗体の陽性率 に比べて低かった。ドックで得られたこれら の陽性率を基にして、平成 4 年10月 1 日現在 の高知県の年令構成から高知県全体のHCV抗 体の陽性者数を計算すると、男性で9372人、 女性で16190人程度と予測された。

GOTPGPTに異常を認めた男性の14\%(26/ 184)、女性の $58 \%(14 / 24)$ にCVV抗体が陽性 であった。GOTやGPTに異常を認めた男性で はアルコール性肝障害と脂肪肝の比率が高い と考えられた。そこで、GOTの值の高さによ ってHCV抗体の陽性率が異なるかを検討して、 図3に示す。GOT（基準值は47IU/L未満）が 男性で97IU/L以上の 6 割が、女性で67IU/L 以上の全員がHCV抗体陽性であった。男性で も、GOTの值が高くなればHCV抗体の陽性率 は増加する。次に、GOTPGPTの異常者の血 液検查の内、他の項目がHCV抗体の有無によ って異なるかを検討した。多くの項目で統計 学的に有意の差を認めたが、代表例として総

図 $2 \mathrm{HCV}$ 抗体陽性率とHBs抗原陽性率

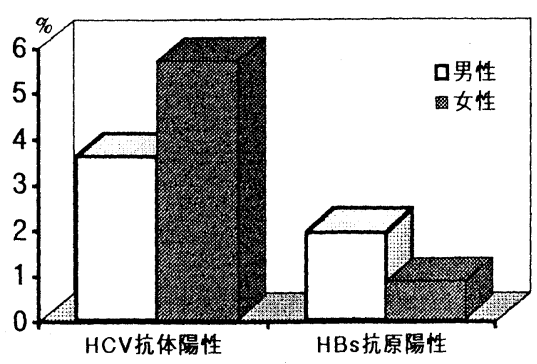

\section{図 1 年齢別のHCV抗体陽性率}



いずれの年代でも女性の陽性率が高かった。 図 2 に示すように、全体のHCV抗体の陽性率

年部区分 
図 3 GOT值とHCV抗体陽性率

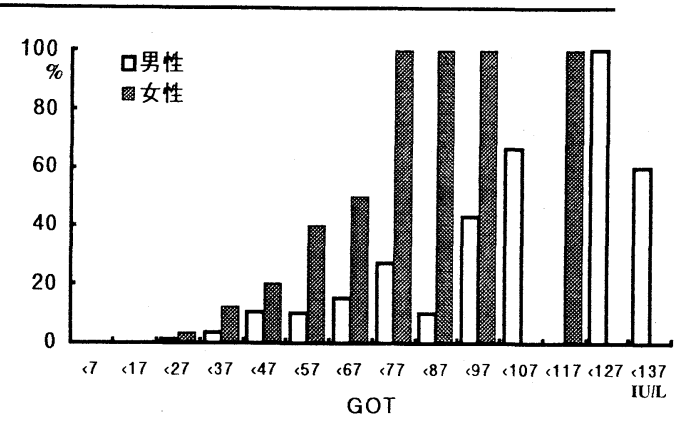

コレステロールと血小板数の関係をHCV抗体 の陽性と陰性に分けて図 4 に示す。GOTPGP Tの異常者の 208 人中 40 人がHCV抗体陽性で、 仮に総コレステロール $190 \mathrm{mg} / \mathrm{d} 1$ 以下で血小板 数が 23 万 $/ \mathrm{mm}^{3}$ 以下で選択すると、 48 人中 30 人がHCV抗体陽性となる。この条件での感受 性は75\%、特異度は90\%、陽性的中率は63\% となった。残りのHCV抗体陰性の18人は全員 が男性で、程度の進んだアルコール性肝障害 が考えられるが、今後病因について検討する 予定である。

逆に、図 5 に示すように男性のHCV抗体陽 性者の38\%(26/69)に、女性の $21 \%(14 / 68)$ にGOTPGPTに異常を認めた。主にHCV抗体 陽性でGOTPGPTに異常を認めた者で、肝生 検を現在までに21例施行した。病理診断別に 総コレステロールと血小板数の関係を図 $6 に$ 示す。肝生検の病理診断は慢性持続性肝炎が、 11例、慢性活動性肝炎が10例であった。また 慢性活動性肝炎は先に示した総コレステロー ルと血小板数の基準以下に $90 \%$ \%含まれた。

当ドックへは高知県下全域から受診があり、 行政区域別のHCV抗体の陽性率を図 7 に示す。 男性で11.2(14/125)\%から1.5(4/262)\%で、 女性で $24.5(24 / 98) \%$ か 2.8(5/179)\%で、 行政区域により HCV抗体の陽性率に大きな差 を認めたが、男女の最高、最低共に同一の行 政区域（市町村）であった。
図4 肝酵素異常者の総コレステロールと血小板数 $\mathrm{HCV}$ 抗体の有無による違い

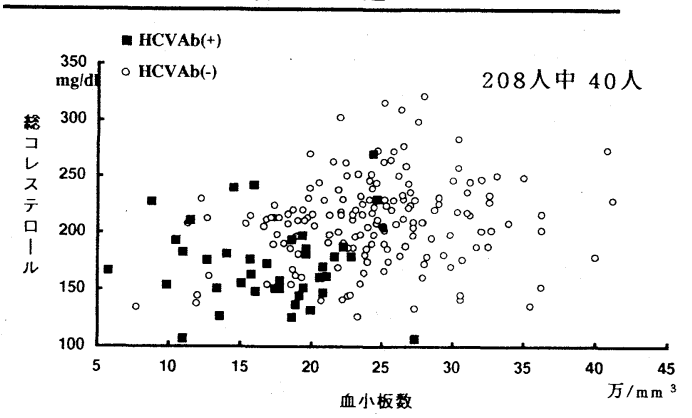

図 5 HCV抗体陽性者における肝酔素異常率

$$
\text { - 男性 } 69 \text { 人中 } 26 \text { 人 女性68人中14人 }
$$

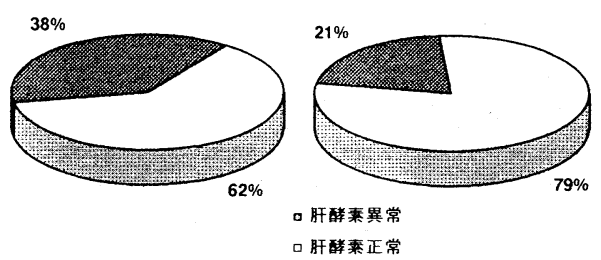

図 $6 \mathrm{HCV}$ 抗体陽性者の総コレステロールと血小板数 C型慢性肝炎の病理診断との関係

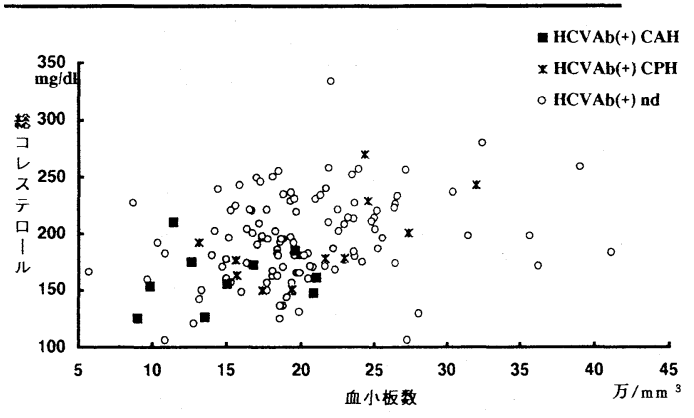

図 7 行政区域別の HCV抗体陽性率

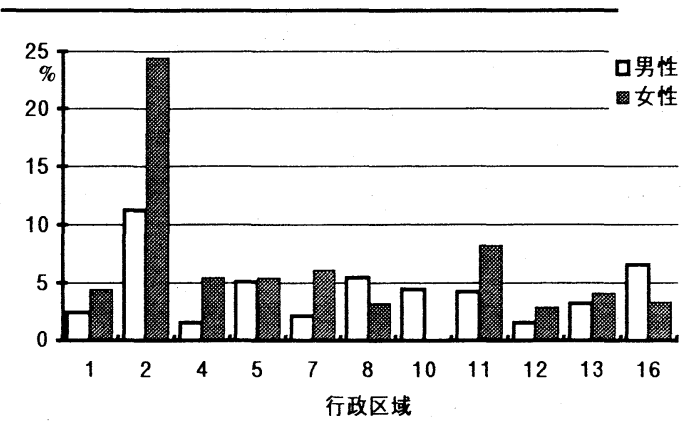




\section{当院における肺結核入院患者の検討 1H10

\author{
○荻原幹雄 井能 仁 平松和代 \\ 高橋 茂 三石晴子 小野 勝 \\ （長野県・佐久総合病院）
}

\section{[はじめに ]}

わが国における結核は年間 5 万千 3 人の新た な結核患者が発生しており、患者の高齢化、 り患率の減少速度の鈍化、重症化などが新た な問題となっている。 当院における肺結核入院患者の実態について 若干の検討したので報告する。

\section{[対象および方法]}

当院の結核病棟に平成 1 年 1 月より平成 5 年 5 月までに入院した肺結核患者67例について性、 年路、入院期間、発見動機、 $x$ 線所見、ツベ ルクリン反応、合併症、在日外国人、治療、 予後などについて検討した。

\section{[結果と考察]}

平成1年1月より平成 5 年 5 月までに当院結核 病棟に入院した肺結核患者は67例であり、平 成 1 年16例、2年 21 例、3年 10 例、4年15例、5年 5例である。男性は38例、女性は29例であり、 性比は男性が1.3倍多い。年齢では70歳代が2 2例 $(33 \%)$ で最も多く、次いで60歳代が 14 例 (2 $1 \%$ )、80歳代が 11 例(16\%) と続き、高齢者の患 者が多く、60歳以上に遍在し、7割を占めてい る。（表 1 ) 平均年齢は64.4歳である。 入院期間は2-3力月間が21例(34\%)で最も多く、 次いで3-4力月間が13例(22\%)であり、6力月以上 は2例に認められる。（表 2 ）平均入院期間は 61日である。当院では結核病棟は最近ベット 数が53床より 33 床と減少したが、稼㗢数は少 ない。

肺結核患者の発見動機として自覚症状があ って医療機関を受診して発見される場合が多
く、58例(87\%)であり、集団検診、ドック、健 康診断などで発見されたものは9例(13\%)であ り、内訳は結核検診が 1 例、ドックが5例、地 域の検診が2例、就職時の健康診断が1例であ る。結核検診のありかたの見直しが必要と考 えられ、また、感染源となり易い塗沫陽性患 者は臨床症状があり、検診では発見しにくい と考えられる。自覚症状は呼吸器症状として は咳、たん、喀血、呼吸困難、胸痛が多く、 全身症状では発熱、全身倦急感、食欲不振、 体重減少、発汗などが多い。咳、たんが長期 に続く患者では肺結核を念頭において検査が 必要と考えられる。

胸部 $\mathrm{x}$ 線所見では学会分類の非広範空洞型 が39例( $58 \%$ )で最も多く、不安定非空洞型が2 2 例 $(34 \%)$ 、広範空洞型6例 $(9 \%)$ である。喀痰の 塗抹染色法によるGaffky号数（表 3) と胸部 $\mathrm{x}$ 線所見のひろがりとは関連が認められない。 ツベルクリン反応では陰性は6例(9\%)に認めら れ、すべて60歳以上で、2例は重症結核例であ る。（表 4 ）加撂にともなう免疫応答の低下 と重症感染の影響と考えられる。

既往歴で肺結核、肺浸潤、肋膜炎の申告の あるものは22例(32\%)に認められるが、ほとん どが60歳以上であり、いわゆる再発と考元ら れる。

合併症としては糖尿病は6例 $(9 \%)$ に認められ、 塵肺は1例、肺線維症は1例、アルコール常用 は3例、ステロイド剤使用1例である。高齢者 では合併症を持つ頻度が高く、複数の合併症 を持つものもある。（表 5 ） 
在日外国人は3例で、20歳代の女性で国籍は タイ人 2 例、フィリッピン人 1 例、では症状発 現から医療機関受診までの掘れが目だち、重 症の粟粒結核となってから受診した例も認め られ、患者側には医療費に対する経済的不安 があり、医療側の対応及び検診や医療費対策 の樹立は急務と考えられる。

治療はイソニコチン酸ヒドラジド、リファ ンピシン、エタンブトールの3剤併用がほぼ全 例に使用され、ストレプトマイシンが4例、エ ンビオマイシンが1例、ピラジナミドが 2 例に 使用されている。リファンピシンによる肝障 害が認められる例があるが、一旦は中止し、 肝機能の回復後、少量より再開し、常用量ま で増量できている。

耐性菌感染による難治性結核は2例であり、 2例とも再治療であり、1例は死亡、1例は長期 入院中である。長期の治療を必要とするため に治療の中断、不規則な服薬などのため耐性
を生じ難治となったと考えられる例が認めら れ、患者の指導と協力の重要性が考えられる。 また、耐性菌に有効な新たな抗結核薬の登場 が望まれる。

死亡例は7例 (10\%)であり、多剤耐性例が 1 例、 重症例が2例、80歳以上の 3 例と 70 歳代の 1 例の 高齢者である。

結核病棟入院患者で非定型抗酸菌症は 10 例 に認められ、全例に Mycobacterium avium complex が同定されている。抗酸菌陽性患者 の内、肺結核菌が67例で87\%を占め、非定型抗 酸菌が $13 \%$ 占めている。

\section{[まとめ]}

肺結核は高齢者に遍在し、合併症をもつこ とが多い。結核検診によって発見される例は 少なく、結核検診のあり方や外国人医療、結 核病棟のあり方、難治性結核の治療などの対 策を検討する必要がある。
表 1 . 性 - 年齢別肺結核入院患者数 (平成 1 年 1 月 -5 年 5 月)

\begin{tabular}{|l|c|c|c|}
\hline 年路 性 & 男 & 女 & 計 \\
\hline 19 歳以下 & 1 & 0 & 1 \\
\hline $20-29$ & 0 & 4 & 4 \\
\hline $30-39$ & 2 & 2 & 4 \\
\hline $40-49$ & 4 & 0 & 4 \\
\hline $50-59$ & 2 & 5 & 7 \\
\hline $60-69$ & 7 & 7 & 14 \\
\hline $70-79$ & 15 & 7 & 22 \\
\hline $80-$ & 7 & 4 & 11 \\
\hline 計 & 38 & 29 & 67 \\
\hline
\end{tabular}

表4 . ツベルクリン反応

\begin{tabular}{|c|c|c|c|}
\hline ツ反 & 陰 性 & 疑陽性 & 陽 性 \\
\hline 患者数 & 6 & 9 & 38 \\
\hline
\end{tabular}

表 2 . 入院期間

\begin{tabular}{|c|c|}
\hline 日 数 & 患者数 \\
\hline $0-30$ & 4 \\
\hline $31-60$ & 10 \\
\hline $61-90$ & 21 \\
\hline $91-120$ & 13 \\
\hline $121-150$ & 10 \\
\hline $151-180$ & 3 \\
\hline $181-210$ & 1 \\
\hline $211-240$ & 2 \\
\hline
\end{tabular}

表 5 . 既往歴

\begin{tabular}{|l|c|}
\hline 肺結核・肺浸潤 & 22 例 \\
\hline 糖尿病 & 6 \\
\hline 麘肺 & 1 \\
\hline 肺線維症 & 1 \\
\hline アルコール常用 & 3 \\
\hline ステロイド使用 & 1 \\
\hline 高血圧 & 9 \\
\hline 心疾患 & 3 \\
\hline 精神神経疾患 & 4 \\
\hline 悪性腫瘍手術 & 4 \\
\hline 痴呆 & 2 \\
\hline 肝疾患 & 1 \\
\hline 痛風 & 1 \\
\hline
\end{tabular}

表3. Gaffky号数

\begin{tabular}{|c|c|}
\hline Gaffky号数 & 患者数 \\
\hline 0 & 6 \\
\hline 1 & 1 \\
\hline 2 & 11 \\
\hline 3 & 10 \\
\hline 4 & 4 \\
\hline 5 & 7 \\
\hline 6 & 2 \\
\hline 7 & 4 \\
\hline 8 & 5 \\
\hline 9 & 5 \\
\hline 10 & 12 \\
\hline
\end{tabular}




\section{$1 \mathrm{H} 11$ エイズに対する認識を深める。}

○城真美子, 永井和子, 浜村幸子, 松島由実, 北村千秋 (三重県厚生連鈴鹿中央総合病院中央手術部)

はじめに

現在，エイズは未だ根治療法が確立されて 扣らず，それ故に多大な恐怖感を人々は持っ ている。しかしそんな事をよそに年々増加の 一途をたどり，当院に打いても我々医療従事 者がエイズ患者に遭遇する事む近い将来だと 推測される。日本の医療現場で感染者への医 療拒否や入院の拒絶等が問題となっている中 で，当院手術室を中心とする医療従事者の工 イズに対する意識はどうか, アンケート調査 を試みた。又接遇に扔いて, 手術室独自のエ イズ患者取扱い方法をまとめたのでててに報 告する。

\section{I 研究目的}

(1)アンケート調査により，エイズ患者に対 する意識を深める。(表一1)

(2)エイズ患者取扱い方法をまとめる。

\section{II 研究方法}

(1)対象一医療従事者50名（手術室スタッフ 医師, 技術補助員)

(2)期間一平成 5 年 3 月 5 月

(3)方法一エイズに関する内容をアンケート 調查する。また，エイズ取扱い方法について は, 肝炎感染者取扱いを参考に, 直接介助者 間接介助者の心得, 手術室各部屋の準備, 器 械や部屋の消毒等, 詳細に検討しまとめる。

\section{III 結 果}

(2)〜 (4)の解答率はそれぞれ(2)は89\%，(3)は $84 \%$ ，(4)は78\%である。(5)のはいと答えた人 は $64 \%$ ，対し，いいえは $36 \%$ ，それについて どう思ったかでは, 看護婦, 技術補助員から
は「エイズ患者専門の医療施設が増えれば。」 「病名によって差別すべきではない」「いち がいにその病院を否定できない。」医師からは

「否定できないのが医療従事者です」と以上 が代表的な解答である。

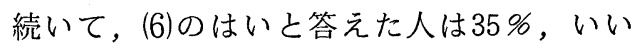
えは $26 \%$ ，その他は $39 \%$ ，その内容として一 番多かったのは「その場にならないとわから ない」である。次いで「細心の注意を払う」

「非感染者に対し，気づかう」「エイズに対 して熟知していれば対応できるのでは」など があげられる。最後に(7)に対し，はい・いい え共に $22 \%$ 。その他が50\%で内容で圧倒的に 多かったのは「その時にならないとわからな い」である。少数で「職務上さけられないだ ろう，しかし積極的と言われると自信がない。」 以上が，アンケート調查の結果である。

尚，エイズ取扱い方法については，研究期 間に打いて，エイズ患者との接遇が幸いにも なく活用する機会がなかった。

\section{考 察}

桜井氏によると「エイズウイルスに対して 人類が持ちうる最大の武器は“正しい知識” である。」と述べている。又「エイズとの闘い に揸いてもうひとつ必要なあのがある。”正 しい認識”である。」提唱している。 患者中心のよりよいケアを提供する上で， 我々医療従事者は, エイズを取り巻く誤解や 偏見をぬぐい去らなければならないと考える。 今回, 取扱い方法をまとめるにあたり，エ イズに対する正しい知識の取得とエイズ患者 
との対応策を検討する事により，正しい認識 ができたのではないかと思われる。

アンケート調査においては,コメントの欄 が充実して書かれていた事等より, 意識の高 まりをうかがえた。

おわりに

エイズ感染者は病気とエイズへの偏見との 孤独な闘いがあるといわれている。我々医療 従事者は常に正しい知識と認識を持ちつつ接

$$
\text { 表一1. アンケート内容 }
$$

今後の研究に役立てたいと思いますので、エイズに関するアンケート調查に御協力抢願い

します。下記の問に対してあてはまるあのに○をつけてください。
(1) 職種
a. 医師
b. 看護婦（士）
c. 技術補助員

（2）エイズの感染経路は、性的接触、母子感染、血液、乙の3つであると思いますか。 (はい いいえ わからない)

(3) エイズの原因であるエイズウイルスは、感染力の強いウイルスであり、B型肝炎などより 伝播力は強いと思いますか。
（はい
いいえ
わからない）

(4) エイズを発症した人と日常生活を共にしても、エイズウイルスに感染しないと思いますか。 （例えば、つり革や扣金・トイレ・衣服やシーッ・風呂やプール・蚊・感染者が作った食 べ物・せきやくしゃみ・食べ物を分け合う・回し飲み・握手や抱擁・普通のキスなど）
(はい
いいえ
わからない)

(5) 医療機関から診察拒否をうけたエイズ感染者がいる事実を知っていますか。 又、知っていた方はそれについてどう思われましたか。
（はい
いいえ)

\section{[}

(6) エイズ患者に接する時、他の疾病患者同様に差別や偏見なく対応することができると思い ますか。

$$
\text { （はい） いいえの他〔 }
$$

（7）職種医師・看護婦（士）の方にうかがいます。 手術に際しては、積極的にたづさわることができますか。
(はい
いいえ
その他〔

(8) 最後にこのアンケート調査について、エイズに関する事、なんでも思うとてろ 御意見・御感想をお聞かせください。 


\section{$1 \mathrm{H} 12$ 北海道中央部農村の住民健診における $\mathrm{C} 100$ - 3 抗体陽性者についての検討}

\author{
旭川厚生病院 ○福井実杉村稂 \\ 旭川医大公衆衛生竹内德男福山裕三
}

対象拉よび方法

北海道中央部農村の比布町 ( 1990 年度 10 月実施）扣よび鷹栖町（1991年6月3〜19日 実施)での健診受診者を対象とした。比布町 受診者数は男性 513 名、女性 649 名で、鷹栖 町では男性 708 人、女性 871 人であった。比 布町、鷹栖町でのC $100-3$ 抗体陽性者のう ち、1992年度に受診し得た者に $2 \mathrm{nd} \mathrm{HCV}$ 抗体特よび一部 HCV RNA の測定を行なっ た。C 100-3 抗体価の測定はOrtho 社の ELISAキットを、2nd HCV 抗体価の測定 は国際試薬のイムチェックーHCV Abキット を用い、HCV RNAの検出は、5-noncoding regionをprimer とする 2 段階PCR法を用 いた。

成 績

1. C 100-3 抗体陽性者の検出

C $100-3$ 抗体陽性者は、比布町では受診 者 1,162 人中男性 34 人、女性 32 人、計 66 人に 検出された。鷹栖町では 1,576 人中男性 21 人、 女性 24 人、計 45 人に検出された。

C 100-3 抗体陽性率は、比布町では5.7 \%、鷹栖町では $2.9 \%$ だった。

Tab le 1 には 2 町の C 100-3 抗体価別 の分布を示す。比布町と鷹栖町では 4.0 以上 の高い抗体価を示した者が、男女とも陽性者 の50\%以上を占めた。

2. C $100-3$ 抗体陽性者に拈ける $2 \mathrm{nd} \mathrm{H}$ $\mathrm{CV}$ 抗体陽性者の検出

1990 年の比布町健診で発見されたC 100 -3 抗体陽性者66人のらち、1992 年の健診
を受診した57について、2 nd HCV 抗体を測 定したところ、49人が陽性だった。1991年 の鷹栖町健診で発見されたC 100-3抗体陽 性者 45 人のうち、1992 年の健診を受診した 36 人について $2 \mathrm{nd} \mathrm{HCV}$ 抗体を測定したとこ ろ、20人が陽性だった。( Table 2)。

3. C 100-3 扔よび $2 \mathrm{nd} \mathrm{HCV}$ 抗体陽性者 での肝機能検査に関する検討

C 100-3 抗体陽性者に括ける $2 \mathrm{nd} \mathrm{HCV}$ 抗体検出率を A L T 值別、C 100-3 抗体価別 に検討すると、比布町の場合、ALT值 $20 \mathrm{KaU}$ 以下の群ではC 100-3 抗体価が高いほど、 $2 \mathrm{nd} \mathrm{HCV}$ 抗体陽性率も高い傾向が少られた。 また ALT值が $21 〜 35 \mathrm{KaU}$ をは $36 \mathrm{KaU}$ 以 上の群ではほとんどC 100-3 抗体価が高く、 全例 $2 \mathrm{nd} \mathrm{HCV}$ 抗体陽性だった。鷹栖町の場 合は、セル当たりの例数が少なかったが、類 似の傾向がみられた。

比布町では $2 \mathrm{nd} \mathrm{HCV}$ 抗体陽性 49例中37例 が ALT 正常例（35 KaU 以下）であった。鷹 栖町では $2 \mathrm{nd} \mathrm{HCV}$ 抗体陽性 20例中 16例が A L T 正常例（35 KaU以下）であった。(Table $2) \circ$

4. 比布町の C $100-3$ 抗体陽性者のうち H CV RNA 検索を実施し得た47例について、 C 100-3 抗体価別、ALT值別に観察した。 ( Table 3)。セル当たりの例数が小さいた め明確ではないが、C 100-3 抗体価が $1.0-$ 1.9 の場合、2.0 以上の群に比して HCV R $\mathrm{NA}$ の検出率は低かった。るた $\mathrm{ALT}$ 值 $20 \mathrm{Ka}$ $\mathrm{U}$ 以下の場合は $21 \mathrm{KaU}$ 以上の群に比して HC 
V RNAの検出率は低かった。ALT值 21$35 \mathrm{KaU}$ では 8 例全例に、 $36 \mathrm{KaU}$ 以上では 8 例中 7 例に HCV RNAを検出した。また、こ れら 47 例中の $2 \mathrm{nd} \mathrm{HCV}$ 抗体陽性者 40 例につ いてみると、 $2 \mathrm{nd} \mathrm{HCV}$ 抗体価が 4.0 以上の 38 例中 35 例に HCV RNAが検出され、 $2 \mathrm{nd}$ $\mathrm{HCV}$ 抗体価 2.0 〜 3.9 の 2 例は HCV R A は検出されなかった。（Table 3)。

Fig.1には、比布町の C 100-3 抗体陽性 者について、2 $\mathrm{nd} \mathrm{HCV}$ 抗体の有無別に、 $\mathrm{A}$ $\mathrm{LT}$ 值拈よび Z T T 值の異常の有無と HCV R $\mathrm{NA}$ 検索の結果を示してある。 $2 \mathrm{nd} \mathrm{HCV}$ 抗 体測定を実施した57例のらら、2 nd HCV 抗 体陽性だった49例について、1990〜1992 年の 3 年間のらち少なくとも 1 回の異常が観 察されたものを異常ありとしてALT值および Z T T 值の異常の有無別にみると両者異常が 16例、ALTのみ異常が 6 例、ZTTのみ異常 が14例、両者正常が13例だった。これら49例 のらち HCV RNA 検索を実施し得た40例につ いてみると、両者とも異常の場合 11 例中 10 例 に、ALT のみ異常の場合 5 例全例に、ZTT のみ異常の場合 14 例中 13 例に HCV R NAが検 出された。両者とも正常の場合 10 例中 7 例に $\mathrm{HCV}$ R NAが検出された。

他方、 $2 \mathrm{nd} \mathrm{HCV}$ 抗体陰性だった 8 例につ いてみると両者とも正常が 7 例、 ZTT のみ 異常が 1 例だった。これら 8 例のうち $\mathrm{HCV}$ RNA を検索しえた 7 例については、いずれ も HCV RNAは陰性だった。
Table 1. C100-3 seropositive persons according to cut-off index

\begin{tabular}{ccccc}
\hline \multirow{2}{*}{ Cut off index } & \multicolumn{2}{c}{ Pippu } & \multicolumn{2}{c}{ Takasu } \\
& Males & Females & Males & Females \\
\hline $1.0-1.9$ & $4(11.8)$ & $3(9.4)$ & $2(9.5)$ & $1(4.2)$ \\
$2.0-2.9$ & $2(5.9)$ & $8(25.0)$ & $1(4.8)$ & $1(4.2)$ \\
$3.0-3.9$ & $7(20.6)$ & $5(15.6)$ & $4(19.0)$ & $6(25.0)$ \\
$4.0-5.1$ & $21(61.8)$ & $16(50.0)$ & $14(66.7)$ & $16(66.7)$ \\
\hline Total & $34(100)$ & $32(100)$ & $21(100)$ & $24(100)$ \\
\hline
\end{tabular}

Table 2. 2nd HCV seropositivity by C100-3 titer and ALT level

\begin{tabular}{|c|c|c|c|c|c|}
\hline \multirow{2}{*}{$\mathrm{ALT}(\mathrm{KaU})$} & \multicolumn{4}{|c|}{ C 100-3 titer (COI) } & \multirow[b]{2}{*}{ total } \\
\hline & $1.0 \sim 1.9$ & $2.0 \sim 2.9$ & $3.0 \sim 3.9$ & $4.0 \sim$ & \\
\hline \multicolumn{6}{|l|}{ Pippu } \\
\hline$\sim 20$ & $3 / 6$ & $6 / 8$ & $4 / 6$ & $13 / 14$ & $26 / 34(77 \%)$ \\
\hline $21 \sim 35$ & - & - & $1 / 1$ & $10 / 10$ & $11 / 11(100 \%)$ \\
\hline $36 \sim$ & - & $1 / 1$ & $3 / 3$ & $8 / 8$ & $12 / 12(100 \%)$ \\
\hline total & $3 / 6(50 \%)$ & $7 / 9(78 \%)$ & $8 / 10(80 \%)$ & $31 / 32(97 \%)$ & $49 / 57(86 \%)$ \\
\hline Takasu & & * & & & \\
\hline$\sim 20$ & $0 / 2$ & $0 / 1$ & $1 / 6$ & $5 / 12$ & $6 / 21(29 \%)$ \\
\hline $21 \sim 35$ & - & - & $1 / 1$ & $9 / 9$ & $10 / 10(100 \%)$ \\
\hline $36 \sim$ & - & $1 / 1$ & $0 / 1$ & $3 / 3$ & $4 / 5 \quad(80 \%)$ \\
\hline total & $0 / 2(0 \%)$ & $1 / 2(50 \%)$ & $2 / 8(25 \%)$ & $17 / 24(71 \%)$ & $20 / 36(56 \%)$ \\
\hline
\end{tabular}

Table 3. Detection of HCV RNA by ALT level and C100-3 titer or 2 nd HCV titer

\begin{tabular}{|c|c|c|c|c|c|c|c|c|}
\hline \multirow{2}{*}{ ALT (KaU) } & \multicolumn{4}{|c|}{ C 100-3 titer (COI) } & \multirow{2}{*}{ total } & \multicolumn{2}{|c|}{ 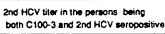 } & \multirow{2}{*}{ total } \\
\hline & $1.0 \sim 1.9$ & $2.0 \sim 2.9$ & $3.0 \sim 3.9$ & 4.0 & & $2.0 \sim 3.9$ & $4.0 \sim$ & \\
\hline$\sim 20$ & $2 / 6$ & $5 \pi$ & $2 / 4$ & $11 / 14$ & $20 / 31(64.5 \%)$ & $0 / 2$ & $20 / 22$ & $20 / 24(83.3 \%)$ \\
\hline $21 \sim 35$ & - & - & - & $8 / 8$ & $8 / 8 \quad(100 \%)$ & - & $8 / 8$ & $8 / 8 \quad(100 \%)$ \\
\hline $36 \sim$ & - & $1 / 1$ & $1 / 2$ & $5 / 5$ & $7 / 8 \quad(87.5 \%)$ & - & $7 / 8$ & $7 / 8 \quad(87.5 \%)$ \\
\hline total & $\begin{array}{c}2 / 6 \\
(33.3 \%)\end{array}$ & $\begin{array}{c}6 / 8 \\
(75 \%)\end{array}$ & $\begin{array}{c}3 / 6 \\
(50 \%)\end{array}$ & $\begin{array}{l}24 / 27 \\
(88.9 \%)\end{array}$ & $\begin{array}{l}35 / 47 \\
(74.5 \%)\end{array}$ & $\begin{array}{l}0 / 2 \\
(0 \%)\end{array}$ & $\begin{array}{l}35 / 38 \\
(92.1 \%)\end{array}$ & $\begin{array}{l}35 / 40 \\
(87.5 \%)\end{array}$ \\
\hline
\end{tabular}



Fig. 1. Reassessment of $\mathrm{C} 100-3$ seropositive persons by $2 \mathrm{nd} \mathrm{HCV}$ Fig. 1. Reassessment of $\mathrm{C100-3}$ seroposit 


\section{$1 \mathrm{H} 13$ 遺族アンケート調査を通じてターミナルケアを考える}

厚生連高岡病院 $3-5$ 病棟

前田美由紀 柴田由美子 福田智恵子

はじめに 堀崎浩美赤江郁子田中澄子 日々私達は看護していくうえで、(1)体力の低 最近、ターミナルケアへの関心が高まるに つれ、癌告知の是非、ターミナルケアにおけ る患者、家族への関わりについていろいろ論 議されている。当病棟においても、手術や化 学療法の甲斐なく、癌末期の疼痛や苦痛を訴 え、再入院し病院で死を迎えられる患者さん が年間約 80 名を数える。これまでデスカン ファレンスを行い、その看護について振り返 り、苦痛や疼痛の緩和を図りながら、最後ま で生への援助を行ってきた。そこで私達は、 ターミナル期を支えた家族がどのような思い で患者さんの死を受けとめていたかを知りた く遺族アンケートを行った。その結果、家族 と私達では、患者さんの死への不安について の語り方が違っていたり、病院で臨終を迎え たことについて家族にはさまざまな思いがあ る事が分かったので報告する。

\section{I ・ 研究方法}

調查方法 : 郵送によるアンケート調査

対象 $: \mathrm{H} \cdot 3$ 年 1 月 $\mathrm{H} \cdot 4$ 年 4 月

10 日までの死亡患者の家族 60 名

在院期間が 1 週間以上 1 か月

以内

回収率：55\%60名中33名の回 答

\section{II 結果及び考察}

今回、このアンケート調査を行った結果、 患者さんは病名を薄々知っていたという家族 が2 5 名あった。そして、何らかの死の不安 を訴えていたという家族は 10 名であった。

下を感じて(2)身の回りのことが一人でできな くなった(3)食べれなくなった(4)痛みや苦痛が 強まった(5)病名を知った事により多くの患者 さんから死への不安について聴いている。し かし、家族に対しては看護婦に話すほど死の 不安について話していないことが分かった。 これには 3 つの点が考えられる。1つは家族 が患者の死を受け入れたくないという心の葛 藤があり、患者さんと家族とのコミュニケー ション不足。2つは、患者さんの家族に対す るいたわりの気持ち。3つは、患者さんが医 療者に話す気持ちと家族に話す気持ちに違い があると思われる。1つについては、患者さ んと家族がコミュニケーションを十分にもて るように配慮したり、家族が身近に迫る死を 受容し、患者さんの人生最後の有意義な時間 を共に過ごせるよう配慮していく必要がある。 2 については、柏木は患者が自分の死につ いて語らないのは、理由の1つとして、患者

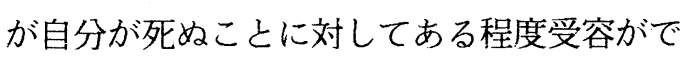
きていて、死のことを話題にすることによっ て周囲が困惑しないように、いわばいたわり の気持ちから死を語らない。」と言っている。 3については、私達は患者さんと信頼関係を 保ちながら、患者さんの真意を洞察していく ことが大切であると考える。疼痛や苦痛の対 処について私達は、医師、家族とも話し合い 薬物の使用はもちろん、色々な工夫を重ね、 日々苦痛の緩和を最優先に行っている。しか し、痛みをはじめとする苦痛をなかなか取り 
除けずに、麻薬による副作用の出現など、私 達自身ジレンマに陷っているのが現状である。 痛みや苦痛の緩和に対してアンケートでは、 23 名の家族から満足しているという回答が あった。しかし、不満足・どちらとも言えな いという家族が 10 名おり、不満足の要因(1) 患者の思うようにしてくれなかった(2)対処の 仕方が遅かった(3)患者の言いなりに薬を使い 過ぎていた、などに加えて何らかの不満をもっ ている家族は約 3 割を占めると判断できる。 また、身の回りのケアについては 32 名中、 清拭については 3 名、排泄面については 4 名、 又洗面・洗髪については3名の人がそれぞれ 不満足之答えている。看護婦の対応の仕方に 何らかの不満をもっていると答えた10名の家 族は、身の回りのケアについても不満足と答 えている傾向にあった。この 2 つの間には相 関関係があると言える。また意見として、全 身に及ぶ浮腫で少しの体動も息苦しさがあり 酸素吸入をしていた患者さんの家族より、入 院中に洗髪をしてもらえなかったという不満 があった。この患者さんについてはカンファ レンスを行い、ドライシャンプーという方法 を行っていたが家族によっては不満となって いた。又一方では、家族の協力もあり、死の 前日に特浴に入浴した患者の家族より、大き な風呂にいれてもらい感謝しているという言 葉を貪った。このことから私達は、患者さん によってより安全で安楽な方法でケアを行う ために、家族と十分に話し合う必要性を感じ た。次に臨終を病院で迎えたことについては、 30 名の家族が満足していると答えている。 また、在宅で死を迎えさせたかったと答えた 3名は、疼痛・苦痛の緩和を図れずに不安が 募り見守ることができなかったと答えている。
満足しているという家族の中にも、本当は在 宅で看ていきたいが、末期の状態をみて不安 になり、入院し病院で臨終を迎えたことで一 応は満足している家族は多いと思わ抽るこ のことからも最期まで在宅で看取り終えるこ との難しさを感じた。

\section{III・終わりに}

今回アンケート調査を行い、回収率が 55 $\%$ と低く家族の気持ちが十分くみ取机かっ たことは残念だった。最後に、地域医療との 連携という大きな課題はあるが、患者さんの $\mathrm{Q}$ ・O・Lを尊重し、より多くの時間を家族 の中で暮らせるように、訪問看護を充実させ ていきたいと思う。

<引用・参考文献 $>$

1)柏木哲夫 : 死にゆく人々のケア

第一版 P88 医学書院 1988

2)芳賀敏彦 : 週末期看護マニュアル

第一版 医学書院 1990

3)柏木哲夫 : 死にゆく患者之家族への援助

第一版 医学書院 1986

4) 岡安大仁 : ターミナルケア医学

第一版 医学書院 1989

5)館由美子 : 未期患者の家族の求める医療

第15回日本看護学会（成人看護）

P 60〜62 1984

6)山崎文子他 : ターミナルの現場から

看護実践の科学 P 78 81 1990 
$1 \mathrm{H} 14$ 秋田県厚生連, 5 病院の癌の告知等に対するアンケート調査

\section{(う黒川博之、高橋孝夫、杮崎廣子、斎藤千枝子、奥山繁子、菅レイ子、年、高崎敏子 ${ }^{6)}$ 仙北組合総合病院 放射線科 ${ }^{1)}$ 同看護婦長 ${ }^{2)}$ 由利組合病院看護婦長 ${ }^{3}($ (以下同じ) 平鹿総合病院（雄勝中央病院， (4)本組合病院 ${ }^{6)}$}

\section{1.はじめに}

近年、インフォームド・コンセントや、医師の告 知義務と患者の知る権利、等についての議論が医療 の現場以外でも盛んなよらである。しかし、日本国 内に招いてこれらの問題に必ずしもコンセンサスが 得られていないのが実情である。我々はこの問題に ついて、秋田県の県南地方の 4 病院と県北の 1 病院 を対象にしてアンケート調查を実施した。

\section{2. 対象および方法}

秋田県厚生連の仙北、由利、平鹿、雄勝、山本、 の 5 病院の看護婦全員を対象にして、別表のような アンケート表を配布して記入してもらった。調査期 間は 1993 年 4 月 7 日から17日までの11日間であった。

\section{3. 結 果}

仙北 318, 由利 307 , 平鹿 311 , 雄勝 216, 山本 231. の合計 1,383 名から回答を得た。回答率は 92.28〜99.06\%であった。5 項目の質問に対する回 答を集計し円グラフにした。辛た別に各病院別の集 計もまとめた。これについては各病院間の回答は高 い類似傾向、相関傾向を示した。各質問に対する最 も多い回答は、いずれもAであり、質問 1 で77.4\% 同 2 が $62.0 \%$ 、同 3 が $87.7 \%$ 、同 4 で $66.1 \%$ 、同 5

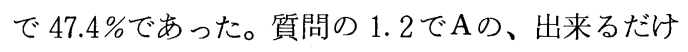
詳しく知りたいを選んだものはそれぞれ 77.4, 62.0 \%であった。特に癌の告知についての質問 2 で告知 希望のA，Bを合わせたものは約82から88\%と高い ものであった。さらにこの問題を確認する形の質問 4 でも約 $77.8 \%$ から $87.4 \%$ であった。しかしながら 一般論とした場合の質問 3 では、その患者さんの精 神状態や性格等による、としたものが最多で $87.7 \%$ であった。放射線照射に関する表現の問題について は、はっきり放射線と告げるのがよいとしたものが $47.4 \%$ 、電気をかける、といら暧昧な、または間接


だものはその理由として最多のものは根治した場合 の後遺症の問題が $66.0 \%$ あった。後者を選んだも のはその理由として習慣的にこれで問題なしとする

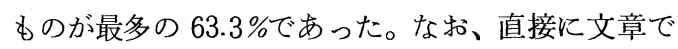

の回答も多数あったが、今回の検討からは外した。

\section{4. 考察}

調査期間が短かったにも拘わらず 92 2 9 \%の高 い回答率をえた。第一に回答から各病院間でかなり 高い相関関係を示した。これは病名、医療方針の公 開等については医療者の間ではすでにコンセンサス が出来上がっているものと思われる。第二に意識の 上からは医療内容の積極的な情報公開の要求は高い ものがあった。しかし第三に、今回の結果からみて も自身のことと仮定した場合と、一般論とした場合 で少なからず、告知に対する差がみられていること からも自分自信が現実にその立場にいたった場合は 告知希望はまた異なるであろらことは容易に推察出 来る。また、このアンケートは医療者へのものであ ることに十分留意する必要がある。

\section{アンケート}

1. 仮にあなた自身が病気になった場合、その病名、 検査内容、治療方針、病状の経過等について、ど の程度医師から説明を受けたいと思われますか。

A 出来るだけ詳しく知りたい。

B 医師の判断にまかすが簡単に知りたい。

C医師にすべてまかせる。

2. 仮にあなた自身が治りにくい病気（進行した癌 やそれに類似する病気）になったと感じられる場 合、その病名を知りたいですか。
A 詳しく知りたい。
B 要点は知りたい。
C 医師の判断にまかせる。
D 都合の悪いことは知りたくない。
E 無回答、その他。
3. 一般論として、患者さんの病気が治りにくく、 かつ治療の効果もあまり期待出来ない場合でも患 者さんに病名を含めて真実を告げるべきだと扔考 えですか。

A その患者さんの精神状態や性格、等による。

B はい。 C いいえ。 D 無回答、その他。

4. もしも、あなたの病気が治りにくい場合、医師 があなたに対して病名、その他を告げるといらこ とを家族が反対している場合には 
A 自分のことは自分で知りたいので直接に医師か ら聞きたい。

B あえて、知りたくない。C 家族に任せる。

D 家族から時期をみて知らせてほしい。

$\mathrm{E}$ 最後まで知りたくない。F 無回答、その他。

5. 放射線治療を開始する場合、患者さんへの説明


として。

A はっきり放射線をかけるといらのがよい。

B 電気をかけるといらのがよい。

C いずれ、放射線という言葉は使用しないのが よい。

D 無回答、その他。
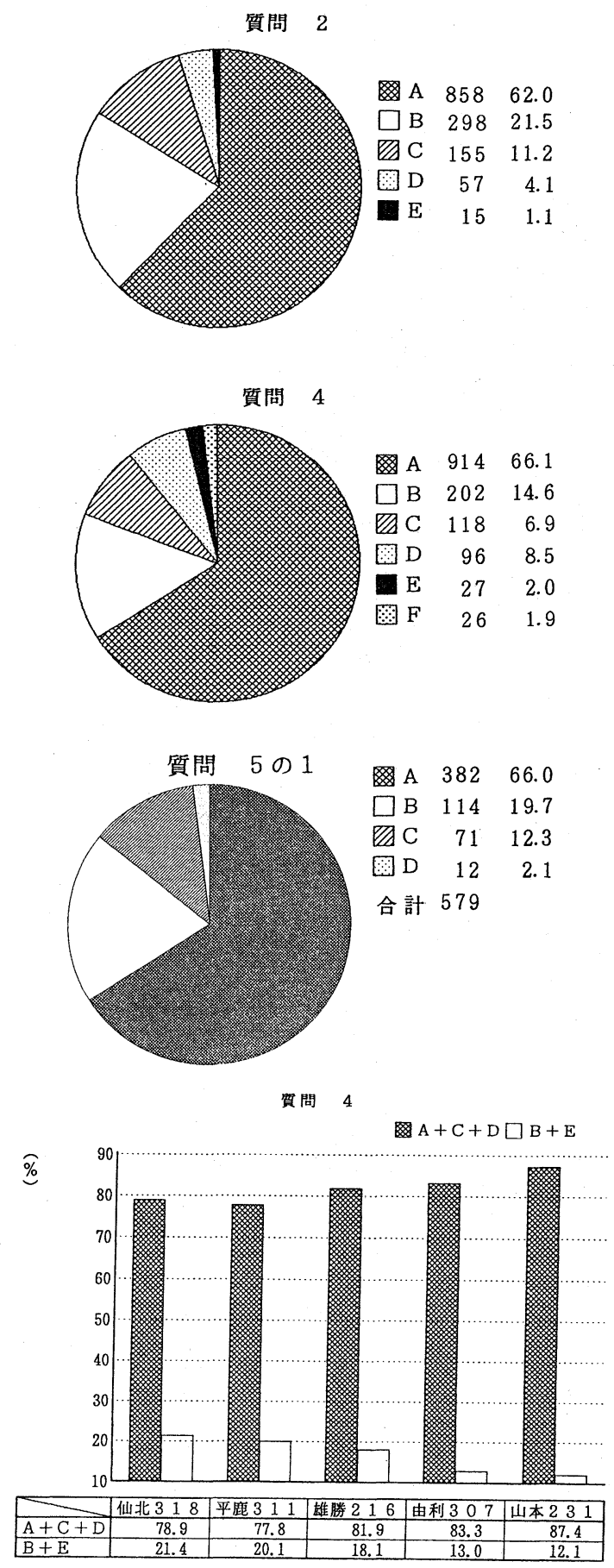


$$
\text { ターミナルケアを考える }
$$

一アンケート調查よりー

\section{徳島県厚生連阿波病院}

\section{I .はじめに}

当院では、平成元年度より看護部門の目標 の一つに、「ターミナルケアの充実」をかかげ 積極的にとりくんでいる。当病棟は、重症患 者を多く受け入れているため、年間約 60 名の 方が亡くなられている。それだけに看護婦は 臨終の場面に立ち会う機会も多くなり、その 場にいあわせる者として、「もう少し苦痛を 取り除いてあげればよかった」「もっと何かが できたのでは」などの言葉を度々耳にするよ うになってきた。

今回当病棟の看護婦を対象に、死にゆく人 々の援助をどのように行っているか現状を記 述してもらい、そのなかから問題を見いだし どうすれば患者・家族のニーズに対応した看 護ができるかについて検討する機会を得たの で報告する。

\section{II. 方法}

(1)調查対象

当病梀に勤務する看濩婦 17 名（経験年 数、年䊩別構成 表 1 参照)

(2)調查方法 記述式アンケート

(3)アンケート質問項目 (表 2 参照)

\section{III. 結果 (表 $3 \sim 7$ 参照)}

質問項目(1)の内容を表 3 に示した。主だっ たものを挙げると(1)痛み苦しみに立分対応で きなかったこと。(2)虫者の年䊩が若かった場 合。(3)排泄介助、清拭等、身の回りの援助で 喜んでくれたこと、などである。

質問項目(2)の内容を表 4 に示した。主だっ
○奥村朋子 三浦由美子 半田真理子 加藤恵美子 原田道代

たものを挙げると(1)精神的援助が足りない(2) 痛みに対して薬だけでなく、もっと他の方法 で援助できなかったか。(3)医阿と家族との䦕 に入って、コーディネイターとしての役割を 果たす。(4)残された日々を充実したものにし てあげたかった。(5)家族への援助不足、など である。

質問項目(3)の内容を表 5 に示した。主だっ

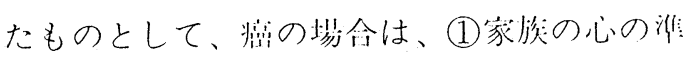
備ができている場合が多い。(2)患者の思いや希 望が優先される。(3)家族を含めた粗神们な不 護がより必要となる。急変時の場合は、(1)異 常をみつける観察力と適切な処置が行なえる。 こととなっている。

質問項目(4)の内容を表 6 に示した。主だっ たものとして、(1)精神的にも疲れているので 言葉がけをして気唒りを忘れない。(2)家族の 希望も許す限り受け入れて奏行に们けて努少 する。(3)家族への情報提供者となる。

その他の内容を表 7 に示した。(1)告知やイ ンフォームドコンセントについて考えていく。 (2)安らかな死を迎えるにはどうしたらよいか 考える、が挙げられる。

全体的にみると、看護婦の経騟年数や年歯 による大きな意見の違いはなかったが、比挍 的若い看蓝婦は一つの物事を一两的にとら之 ているのに対して、経験が啙かになるにつれ て多面的に患者をとらえ次の予测ができてい る様に思われる。

IV. 考察

アンケートの結果から当病悚の看頀婦のも 
つターミナルケアにおける刘応上の問題を集 約すると以下のようになる。

(1)悀みのコントロールが不充分

(2)粗神的援助不足

(3)垁師と想省・家族間のコーディネーター としての役副不足

(4)家族への援助が不光分

(5)磨告知の是非について

これらの䦌題点を解決する方法であるが、 (1)については、まず看熦婦自身が積極的に夕 一ミナルケアに関する勉少会等に参川し、痛 みの緩利について学酱を哚め、その部位、強 さなどを的碓に知ることが必要である。又、

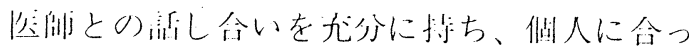
た適切な鎮痛剂の投与が行なえるよう努力す る。

(2)については、医附、不濩婦が䫏回に訲空 し、愳者・家族に言泟がけをして、スキンシ ップを持つことが必倠である。州に㑑人の意

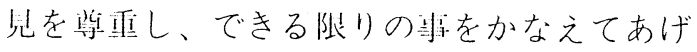

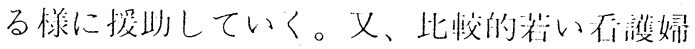
からは、苦しんでいる热者さんの側にいてあ げたいという意見があがっていた。このこと から壆本的な援助の必要性を改めて考之させ られたように思う。自分達の看灌技術につい

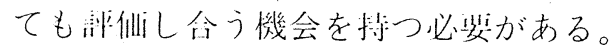

(3)については、ターミナルにある蜆者・家

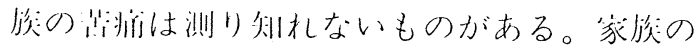

疑問や恼みを家族にかわり医師に伝え、其に その寺剘を乘り越えられるようにとりはから j。

(4)においては、まず基本的な救急看護がで き、そのうえで周囲の人にも目を向け、機敘 な対応ができること、そして、家族には許す 限り側にいて少しでも不安の軽減に努める必 要がある。更に、長期入院想者の家族におい ては、言葉がけや気配りが大切になってくる。 また、家族の悩みを闑いてあげられる時間的 余裕を持つようにしたい。

(5)の告知については、当院では一部を除い てほとんどされていないのが現状であり、こ れからの大きな課題でもある。

V.おわりに

現化当病楝では、ターミナルケアの旮実の ためデスカンファレンスを持ち、その場にい あわせた看護婦を中心に、援終時の状態、そ

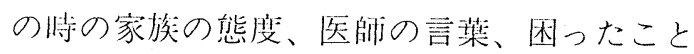
在漼婦の反省等について話し合い、記録とし て残すようにしている。このことは、スタッ フ間の考え方と対応の違いを知ることで自分 の看訬を自己評断できる機会でもある。また、 患者・家族の話もゆっくり閆ける場所の設定 も必要である。今後は、入院時より医師を交

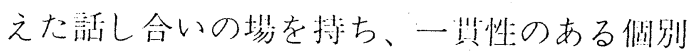
的なケアが行えるよう努力してゆきたい。

〈表1〉年魿·経験年数別構成

\begin{tabular}{|c|c|c|}
\hline 年代 & 人数 & 経瞇年 数 \\
\hline 40 代 & 7 名 & 20年以上 \\
\hline 30 代 & 3 名 & 10年以上 \\
\hline \multirow[t]{6}{*}{20 代 } & 7 名 & 2 年目 ( 1 名) \\
\hline & & 3 年目 ( 1 名) \\
\hline & & 4 年目 $(1$ 名) \\
\hline & & 5 年目 (1名) \\
\hline & & 8 年目 ( 2 名) \\
\hline & & 9 年目 ( 1 名) \\
\hline
\end{tabular}

〈表 2〉アンケート質問項目

\begin{tabular}{|l|l|}
\hline$(1)$ & 患者の死に至るまでの過程で心に残ったこと \\
\hline$(2)$ & $\begin{array}{l}\text { 患者の死に至るまでの過程でもっとこうすれば } \\
\text { よかったと思うこと }\end{array}$ \\
\hline$(3)$ & $\begin{array}{l}\text { 癌の睤者とそれ以外の疾患で急変した患者の看 } \\
\text { 護でどんなところが違うと思うか }\end{array}$ \\
\hline$(4)$ & 家族にこうしてあげたら良かったと思うこと \\
\hline$(5)$ & その他 \\
\hline
\end{tabular}




\section{$1 \mathrm{H} 16$}

\section{混合病棟に扮ける夕ーミナル期の看護}

一長期入院となった癌再発患者のケアを通して一

O佐藤美智子, 佐藤恵子, 伊藤と〈子, 薄場 修 $^{1)}$, 松元 茂 $^{2)}$,

今田文子, 松井京子

1.はじめに

癌再発患者のケアにおいては，本人の満足の 行く入院生活が遅れるよう援助することが望まし い。しかし，当病棟の様な一般混合病棟において このような患者のQOL (Quality of life)を重視した ケアを行なおうとした場合, 患者間あるいは患者・ 看護婦間に諸問題が生じることがある。また，極 端な場合，他患者の入院生活に支障を来たすこと もある。今回, 定期的なケース・カンファレンス により問題解決を検討した長期入院癌再発症例を 経験したので報告する。

\section{2 . 症例呈示}

症例：51歳，女性。診断名：直腸癌（手術後）, 局所再発。併発症：排尿困難（自己導尿），仙骨 転移。

職業: 飲食店経営, 家族構成：長男と 2 人暮 らし，夫は未入籍，県外に長期滞在中。

[現病歴]

平成 2 年 7 月 直腸癌手術, 人工肛門増設。

3 年 4 月 左雉部痛, 次第に増強。

8 月 塩酸モルヒネ内服開始。

10月 疼痛増強（鎮痛薬の不確実な 内服），局所再発が認められ

\section{入院。}

\section{[入院経過］（図参照）}

入院後は硫酸モルヒネ徐放錠（MSコンチン $\left.{ }^{\circledR}\right)$ の増量, 確実な内服により比較的症状は安定して 経過した。入院が長引くに従い, 我がまま, 横柄 な態度が目立つようになり，同室者（6人室）か ら苦情が寄せられるようになった。一方, 再発に 対する不安が強く，看護婦に対して疑問を投げか けることが多く認められるようになった。これら の問題を解決していくために，平成 4 年 1 月 16 日 第 1 回ケース・カンファレンスが開催され，その 後主治医，担当看護グループ，ペインクリニック 科医師等により，ほほ $1 \sim 2$ 週間の間隔で継続的 に開催された（反省会を含め計10回）。
看護室, 外科 ${ }^{1)}$, ペインクリニック科 ${ }^{2)}$

\section{3. 考察 (表参照)}

ケース・カンファレンスで検討された問題点 は表のごとく 4 点に分類された。

疼痛管理はMSコンチンの内服の指導, モルヒ 亦持続静注，さらに骨転移痛に対しての放射線療 法等により比較的良好であった。精神・心理面の 管理に関しては，自分の病気が癌であるという認 識は持っていたが再発に対する不安が強く, 看護 婦に疑問の投げかけが頻回に見られるようになっ たため対応に苦慮した。カンファレンスにて病名・ 病状説明について検討されたが，家族的背景，性 格の問題を考慮し，再発の事実を告知することは 困難であると判断された。現在の病状, 疼痛の原 因等に関して，患者が希望を失うことがないよう に統一した見解でスタッフが対処するように申し 合わせた。入院が長期にわたったこともあり，次 第に我がもの顔の言動が目立つようになった。力 ンファレンスにて，入院中の協同生活を乱すよう な言動に対しては夕ーミナル期の患者だからといっ て特別扱いはしないで対処するという方針が示さ れた。家族の関わりに関しては，息子に対して 「治癒不可能な状態であり, 患者の不安軽減のた めには家族の協力が不可欠である」という説明が されているにも関わらず，面会も少ない状況であっ た。カンファレンスにて医療者側からもっと積極 的に働きかける必要があるという結論がなされ， 外出, 外泊の受け入れを息子だけでなく妹等に対 しても働き掛けた。その結果, 近親者の面会の増 加, 外出, 外泊の実現がなされ, 終末期には自分 の誕生会に外泊参加し喜び満足して帰院するなど 精神的安楽が得られるようになった。

本症例のような身体, 精神, 社会的に複雑な 病状を呈する夕ーミナル期の患者に対するケアは, 病状, 病態の異なる様々な患者を抱えている混合 病棟に扔いては不十分になりがちである。今回， 定期的ケース・カンファレンスを開催し，患者の 全体像の把握に努めそこから生じてくる種々の問 題解決の検討に取り組みその方針に基づき看護で きたことは，非常に有意義でありスタッフのター ミナル・ケアに対する看護意欲の向上にもつながっ た。 
表 看護上の問題点と対策

\begin{tabular}{cl}
\hline \hline \multicolumn{1}{c}{ 問題点 } & \multicolumn{1}{c}{ 対策（看護内容） } \\
\hline (1) 疼痛など症状に対して & 鎮痛薬の内服指導, 管理 \\
敏感, 神経質 & 希望時のマッサージ, 注射 \\
(2) 再発に対する強い不安 & 心理状態の把握 \\
疑問の投げかけ & 言動の統一 \\
(3) 自己中心的で, 他患者との & 入院生活のマナー指導 \\
協調性にかける & 特別扱いをしない \\
(4) 家族との関わりが薄く, & 面会, 外出, 外泊に関して \\
協力が得られない & 家族に働きかけ \\
\hline
\end{tabular}

図入院後治療・看護経過

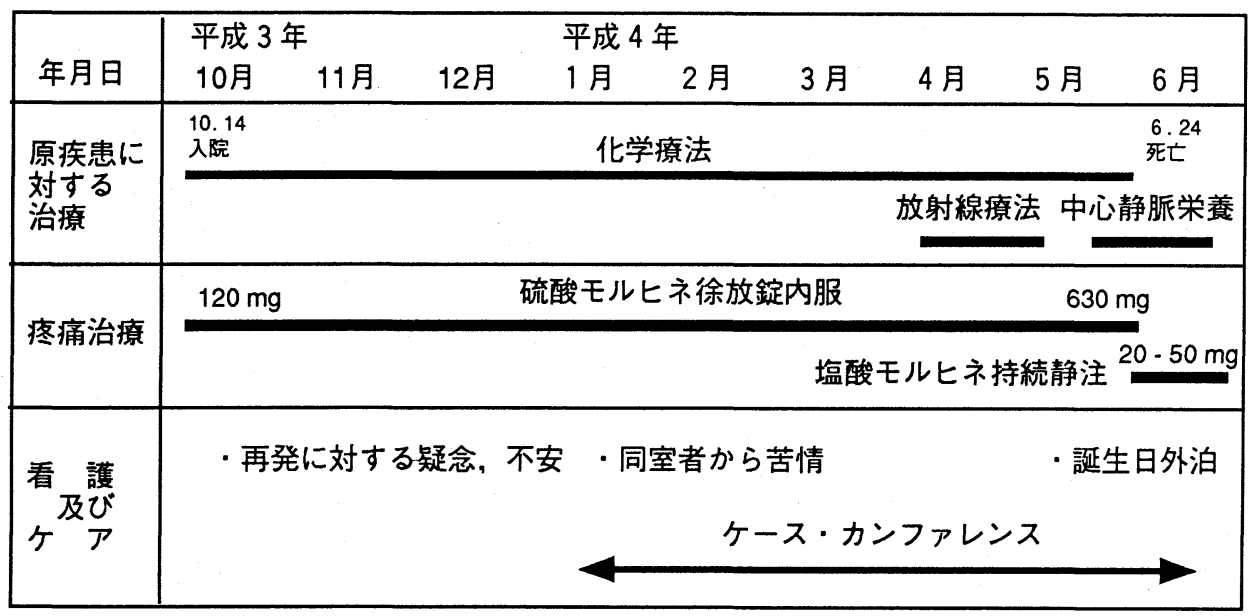




\section{H17 ターミナルケアにおける家族の関わり}

(はじめに)

癌末期の患者においては、在宅療養（以下 在宅之略す) ケアの必要性が高いにも関わら ず、介護力の不足や急変時の処置に困る等、 様々な理由から家族の受け入れが不十分なケ 一スが多く、患者のＱＯＬ向上が難しい状態 にある。

今回、消化器内科病棟において癌末期患者 の家族を支援することで、外泊および在宅を 可能にした 5 事例を経験したので報告する。

\section{(看護評価)}

事例 $\mathrm{A}$ ：患者は在宅できて良かったと言っ たが、家族の介護は大変だったと思われた。 再入院時「ホッとした」という家族の言葉か らも、そのことが同われた。在宅時の応援体 制があれば家族の負担を軽減できたと思う。

事例 B : 妻と息子に在宅時の I V H 指導を 繰り返し、家で過ごしたいという患者の気持 ちを説明したが受け入れられず、残念なケー スであった。お盆に一泊だけの外泊が可能に なったことが、せめてもの救いであった。こ の時帰省中の長男夫婦が、輸液交換して帰る 病棟看護婦を、涙ぐんで見送ってくれた。

事例 C : 夫の思いやりと勇気が在宅を可能 にしたケースであった。在宅生活をして最初 の来院時、夫のことを「信用できる人だ」と 嬉しそうに話したことや、夫婦になってから 初めて二人だけで旅行した事などを聞いて、 在宅時の夫の介護が夫婦の絆を深めたのだと 感じられた。来院時、病棟での入浴処置を継 続し、患者と家族とのコミュニケーションを 大切に支援したことが、長期の在宅という良 い結果につながった。

\section{○堀江 良子・阿部 美紀子・佐々木多恵子 加藤 浜子. 照井美津子. 右谷美知子 秋田県厚生連平鹿総合病院 5 階第 2 看護室(消化器内科病棟)}

在宅が可能になり、曾孫に囲まれて幸せそう であった。農繁期に介護人の不足から病院に 戻らざることをえなかった。しかし、家族全 員で患者の幸せを考え協力を惜しまなかった ので、再入院後二泊の外泊もできた。病院之 家とでは患者の表情が違うことを教えられた ケースでもあった。

事例 $\mathrm{E}$ ：嫁、姑の不仲や、地域的なことな よ゙を理由に在宅を拒否した息子夫婦に、患者 の予後や、住み慣れた家で過ごしたいという 患者の気持ちを伝えることで、息子夫婦が考 えを新たにし、在宅を決心してくれた。嫁、 姑問題は残っているようだが、患者は「病院 よりは家の方が良い」と言い、息子夫婦と共 に通院している。チューブのトラブル発生時 は病棟に電話があり、救急外来紹介をするな ビして対応し、7月現在、フォローを継続し ている。

\section{(考察およびまとめ)}

患者は、大半が住み慣れた家で過ごしたい と思っている。しかし、I V H P P T C D 千 ューブが挿入されていると、家族の不安が大 きく、容易には在宅療養を受け入れない状態 が多い。今回の事例では、家族の負担となる 要素を取り除くための指導を重水、良好なコ ミュニケーションをとっていくことで在宅療 養、外泊を可能にし、患者のＱＯＬを向上さ せることができた。

家族の愛情ある看護で、患者の苦痛は和ら き、希望が生まれてくる。その家族を支える ことも看護の大きな役割であると思う。

今後屯患者および家族支援のチームづくり を進め、少しでも患者と家族が納得できる人 生を過ごせるよう援助していきたい。 







\section{H18}

$$
\text { ターミナルステージで入院して来た }
$$

患者への精神的援助を考える

○和田佳奈子, 佐藤真美（総合病院取手協同病院看護科）

I ・はじめに

$$
\text { ターミナル期の患者が少ない整形外科病棟 }
$$

で、転移性骨腫瘍で入院となった患者と出会 った。患者は癌の告知を受けず、疑念や不安 を抱き続けた入院生活を送った。

予後半年の患者に対して、どの様にしたら 残された日々を家族と共に、その人らしく生 きていくことができるのかを話し合った。そ して患者の頑張りによって一時退院を実現す る事ができた。

今回の症例を通して学んだターミナルケア について再考できたので報告する。

\section{II. 事例紹介}

患 者 MTさん 女性 42才

家 族 夫長男 (中2) 次男 (6才)

診断名 胃癌 (原発)

転移性骨腫瘍（全脊椎、肩関節、 骨盤) 予後 3 ヶ月〜 6 ヶ月

入院期間 H 4.12.24 H 5.2.16

\section{III. 入院中の経過}

\section{IV . 看護の展開}

第 I 期 : 診断が確定せず、病気に対する疑 念が強かった時期

\section{〈看護目標〉}

1. 病気に対する疑問を訴える事ができ、医 療者との信頼関係が築ける

2. 基本的ニードが満たされる

〈看護の実際〉

診断確定のための検査が続き、患者は、 「検査をするって言われてショックで食欲が ない。私は癌じゃないのかしら。」と訴えて きた。

家族の希望で癌告知はされず、医師より “胃潰瘍で良性と悪性の中間位、骨折は炎症 によるもの”と説明を受け、私たちも言動を 統一した。しかし、様々な疑問を投げかけて きた。私達は病室から足を遠ざけたい気持に なったが、一つ一つの疑問に対して医師と相 談しながら対処してきた。

また、長期に及ぶベッド上安静のストレス から、「起き上がって背伸びがしたい。トイ レへ行きたい。」と訴えてきた。それに対 し、「今起き上がると、背骨がつぶれて下半 身麻㿉になる危険性がある。」と説明し、理 解を得た。幸い友人の面会も多く、ベッド 上生活での気晴らしになっていた様子であ った。

第 II 期 : 疼痛や病気に対する不安を抱きな がらも、回復への希望がもて、退院を迎える までの時期 


\section{〈看護目標〉}

1. 疼痛が軽減し、精神的安定が保てる

2. 残された日々を、妻、母親として家族と 触れ合う事ができる

〈看護の実際〉

コルセットを装着し起坐位が許可になり、 その後、端坐位、一週間後には平行棒 2 往復 ができる様にまでなった。「起きると気持が いいわね」という言葉も聞かれたが、「腰や 足がだるくて痛い」と頻繁に訴えるようにな り、夜間は特に、個室で一人になり不安も募 り、 5 分〜10分毎にナースコールが鳴った。 目を見開き、コールを握りしめている M T さんと、数十分も話し込み励ましたこともあ った。

時には、わがままに見えた M Tさんの訴え に、私達は徹底して耳を傾け、話し相手にな つた。M Tさんの看護婦への依頼心は、絶対 的なものとなり、日常の小さな事でも夫より 看護婦に頼んでくるようになった。その責任 の重さに、看護婦の苦悩も限界にきていたが、 徐々に腰痛は軽減し、リハビリも進んできた。 その頃より、主治医の勧めもあり、M Tさ んも私達も、退院を考えるようになった。 「子供が、学校は楽しいけど家には帰りたく ないって泣いたの。」と母親としての気遣い を見せ「下の子の入学式には出席したい。」 と希望、を語るようになった。私達は M Td んの夫と話し合いを持ち、夫もできるだけ自 宅で療養させたいと思っていることを確認し た。夜間の不眠、階段の昇降、入浴などの心 配があったが、「寝ているだけでもいい」と いうM Tさんの言葉にもあるように、家庭の 中で、母親の役割を果したいという気持は強 かった。そして病棟との連絡体制を作り、退 院となった。

\section{V. 考察}

M Tさんは、退院後10日目に再入院とな り、その後37日後に亡くなられた。自宅での 生活は体も思うように動かず、M Tdんにと っても家族にとっても、満足のいくものでは なかったかもしれないが、最後に夫と子供に 囲まれた、一番落ちつけた時ではなかったろ うか。家族と共に過ごした貴重な時間が、意 義あるターミナルの一助になったと考える。

病名を知らされずとも、M Tさんには二度 と自宅へ戻れない予感があったからこそ、不 安を抱きながらも家に帰る事に踏み切ったの だろう。若い頃保母をしていて、看護婦にも なりたかったというM Tさんに、辛い人生の 最後を看護婦に対して要求をぶつけながら も、精一杯生きた女性として深い共感を覚え る。私達スタッフが、最後の日々をM Tさん や家族が望むように生きる援助が少しでもで きていたのだろうか、と反省することも多い が、今回の経験を生かしてこれから一般病棟 でのホスピスケアのあり方を追求していくき っかけとなった。

VI.まとめ

ターミナルの状態を迎えた患者を看護する 時、その人に合った生き方を考え、残された 日々を人間らしく生きられるように援助して いくことの大切さを学んだ。また、患者が家 族の中で果たす役割を考慮し、家族へも援助 できるよう、これからも努力したい。 
$1 \mathrm{H} 19$ 一般総合病院に緩和ケア病棟は必要か？

○松元 茂, 秋山博実, 松本秀一

平鹿総合病院ペインクリニック科, 麻酔科

当科では紹介患者を対象として，積極的に緩 和的医療に取り組んでいる。主な診療内容は, 外 来診察室での問診, 外来治療室あるいは透視室で の神経ブロック，および病棟回診である。患者の 状態が悪化してからは病棟回診が主たる診療内容 となる。当院においては緩和ケア病棟は設置され ていず通常 7 ～病棟の回診を行なっているが， 患者数が多いときなどは全患者を毎日回診するこ とは不可能となる。緩和的医療に携わっている立 場としては緩和ケア病棟の必要性を常に感じてい るが, 病棟での現状はどうなのであろうか? 今回 一般総合病院における緩和ケア病棟の必要性を検 討するために，非根治性担癌患者の入室状況を調 査したので報告する。

I 対象および方法

平成 5 年 2 月抢よび 3 月の 2 回にわたり，当 院の全病棟（10）を対象として調査を実施した。

調査項目: 入院患者数, 担癌患者数, 非根治 性担癌患者数, 非根治性担癌患者の病室のタイプ および一般全身状態。一般全身状態は Performance status score をもちい，5段階で評価し た（表 1)。

II 結果

入院患者総数に対する担癌患者数の割合は, $27 \%$ （2月），26\%（3月）, 非根治性担癌患者 の割合は，16\%（2月），19\%（3月）であった。

（図 1)

非根治性担癌患者の病室のタイプは，6人室 がもっとも多く64.8\%（2月），61\%（3月）， 次いで 1 人室が多く $21.6 \%$ (2月)，16\%（3月） であった（図 2)。

非根治性担癌患者の一般全身状態は, PSS 3 つ いで 4 の症例が多く，日常生活に支障を来たして いるPSS 3，4の症例は $61.3 \%$ （2月），56\% （3月）であった。

非根治性担癌患者の病室と一般全身状態との 関係（図 4，5）では，1２人室入室患者のほ とんどがPSS 3，4で，高度に日常生活が制限さ れている状態であった。全身状態の比較的保たれ ている（PSS 0 2 ）患者はほとんど大部屋（主
に 6 人室）入室であった。しかし， 6 人室入室患 者の半数近くはPSS 3，4の患者であった（2 月 $43.8 \%, 3$ 月 $44.6 \%$ ）。

\section{III 結論}

非根治性担癌患者の約 6 割は全身状態不良で あった。また 6 割以上の患者がいわゆる大部屋に 入室していた。プライバシーが比較的守られる個 室や 2 人室入室患者のほとんどは全身状態不良患 者であった。個室， 2 人室入室に関しては全身状 態の悪化がその目安とされていると思われた。し かし個室, 2 人室の数は限られていて, 全身状態 不良患者の半数以上が大部屋入室であった。当院 に打ける非根治性担癌患者の入室状況と一般全身 状態の評価からは, 緩和ケア病棟は是非必要であ ると考えられた。 
表 1 一般全身状態 (performance status score)

0 : 社会活動ができ，制限を受けることなく発病前と同等にふるまえる。

1 : 肉体労働は制限を受けるが, 歩行, 軽労働や座業はできる.

$2:$ 歩行や身の回りのことはできるが, 軽労働はできない.

$3:$ 身の回りのある程度のことはできるが, 日中 $50 \%$ 以上は就床している.

4 : 身の回りのこともできず, 介助がいり，終日就床を必要とする.

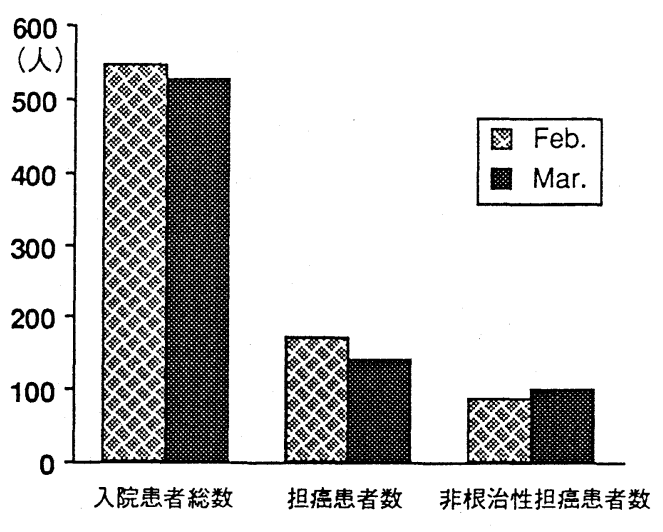

図 1 入院患者数

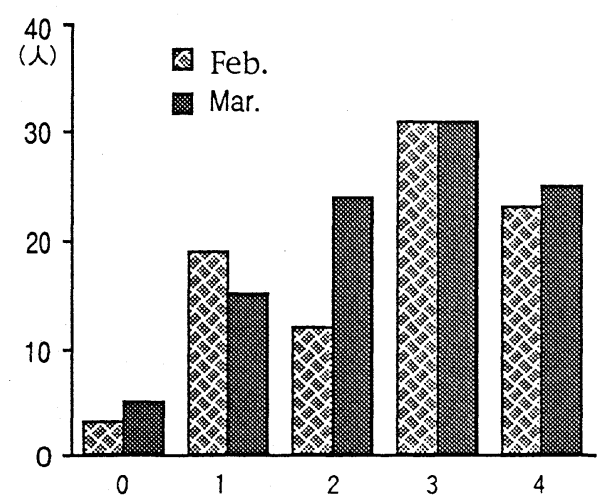

図 3 非根治性担癌患者の一般全身状態

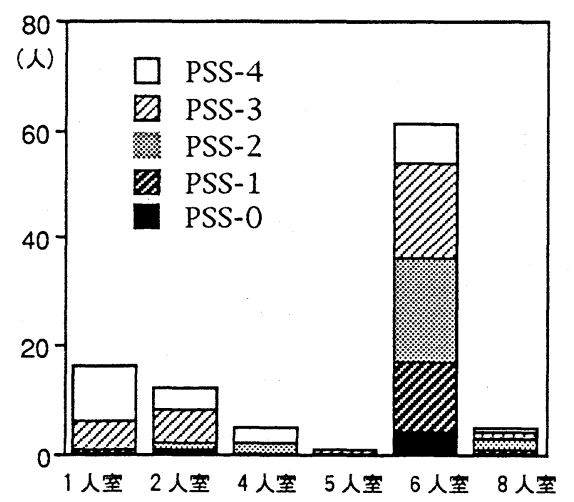

図 5 非根治性担癌患者の病室と一般全身状態 ( 3 月)

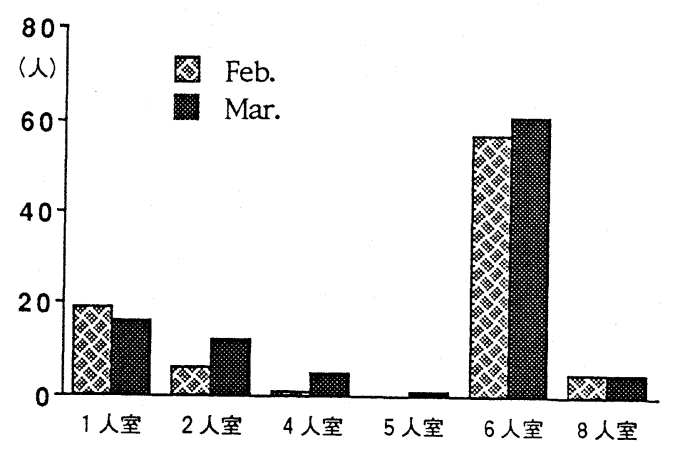

図 2 非根治性担癌患者の病室のタイブ

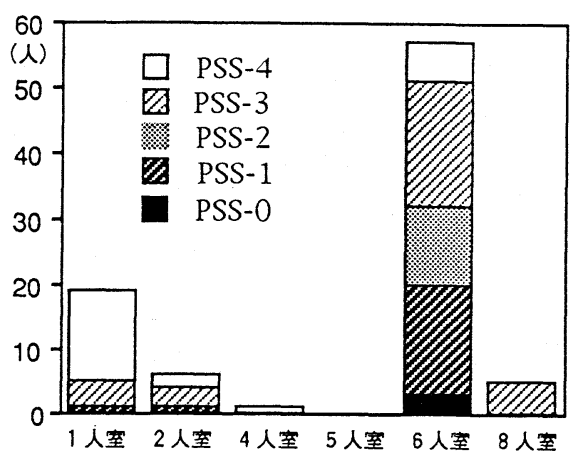

図 4 非根治性担癌患者の病室と一般全身状燱（2月） 
1H20

\author{
在宅癌治療の栄養管理 \\ 一 当病院におけるH P Nのシステム化 - \\ 平鹿総合病院外科病棟 \\ （）平野多津子 東海林友子 本庄千代子 森屋ミ土子 \\ 沢田 純子 藤原ひと美 小西美喜子
}

\title{
【緒言】
}

癌患者における真のQＯLとは何か？、模索しているの が現状でである。当院でも、ターミナル・ケアー研究会を 設立し院内の各分野から参加者を募り議論を重ねている。 その中で、ターミナル・ケアーの指針として癌性疼痛の管 理が十分に出来、かつ輸液栄養管理により Performance Status grade 2 以上に維持出来る患者であれば、最も 憩いの場である自宅で残された日々を過ごして頂くことが 最良のケアーであるとコンセンサスが得られた。そこで、 当病棟では在宅静脈栄養（H P N) 施行時のトレーニング の効率化抒よび安全性の確立を目的として独自にマニュア ルを作成し実施して来た。担癌患者の H P Nは基本的に患 者が compromized host の状態にあるためカテーテル感染 のリスクも高く、通常の H P Nとは違ったきめ細かい管理 が要求される。今回、当病棟に执ける H P N実施状況なら びにそのシステムの有性性について検討を行ったので報告 する。

\section{【方法】}

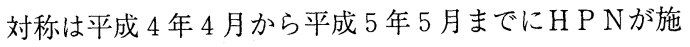
行された12症例である。いずれの患者も進行癌で残念なが ら有効な治療手段がないと判断され、消火管の通過障害な いし悪液質にて栄養管理が必要な状況にあった。男性 7 人、 女性 5 人、平均年齢は63.2歳であった。患者拉よび家族 にH P Nについて説明し、同意を得た後H P Nのトレーニ ングを開始した。中心静脈カテーテルは感染予防に皮下ト ンネルを $10 \mathrm{~cm}$ 以上作成し鎖骨下静脈より挿入された。投与 方法は輸液ポンプを使用し、24時間体制（日中：外科外来、 それ以外 : 外科病棟) とし、患者家族との連絡を密に保っ た。

検討項目は以下の 3 点とした。すなわち、われわれの作 成したマニュアルに扔いて、

(1) H P Nトレーニングの効率

(2)担癌患者に扔けるH P Nの安全性 : 特にカテーテル感染 と閉塞

(3)在宅日数と満足度

の 3 点を検証した。

\section{【結果および考察】}

1） H P N介護者の年齢とトレーニング期間の関係（図 2)

平均トレーニング期間は 13.5 日であった。介護者の内 訳は、夫 4 例、妻 6 例、息子 1 例、侽 1 例であった。介護 者の高齢化にともないトレーニング期間が遷延化する傾向 を認めた。高齢者ではカテーテルラインの接続と輸液ポン プの使用法に戸惑うことが多く、実際の輸液バック交換時 の指導ばかりでなくデモンストレイション用のライン・ポ ンプを準備し繰り返しのトレーニングが必要であることが 示唆された。

2) H P N投与方法

接続投与が 5 例の内、 3 例は傾向摂取がほとんど不能で 接続投与の適用となったが、他 2 例（介護者・患者ともど も高齢）はカテーテルのヘバリン注入・ライン組み立てを どうして煩雑と感じスムーズに出来ず持続投与となった。

3 ) カテーテルトラブル

血栓による閉塞 1 例 $(8.3 \%)$ 、感染 3 例 $(25 \%)$ 、接 続部の亀裂 $(8.3 \%)$ であった。感染を生じたカテーテル の留置期間はそれぞれ 3 カ月、11力月、7 月西方った。 いずれの症例も一度の発熱で直ちに来院し、カテーテル感 染と診断されカテーテルが抜去されており、敗血症等の重 篤な状態に陥ることなくマニュアル通りに適切に対処され た。入院患者 147 例を対象とした当科の1987年の集計で は、感染を生じたカテーテルの平均留置期間は58日であっ た。このデー夕を比較対象とすると、癌末期かつ在宅管理 下にありながら少なくとも 3 カ月は感染を来さずに経過し ていることは、在宅でのカテーテル管理がマニュアルに則 り適正に行われていることを物語っているものと考えられ た。

\section{4 ）在宅期間}

1 力月未満： 1 例、 $1 \sim 6$ 力月: 9 例、 6 力月 1 年: 1 例、 1 年以上： 1 例であった。

5 ) 満足度

H P Nトレーニングを終了し、退院する患者さんは「も う一度、家で過ごすことが出来る」と言う希望に満ちた表 情であった。一方、家族サイドでは「治らないとして、何 かして上げたい」と言う切なる思いが満たれれ、幸い全症 例で満足との解答を預けた。

また、経口掑取がある程度可能な症例では、夜間のみの 
間歇投与法が好評であった。日中、輸液バック・ポンプに 煩わせないと言うのが最大の理由であった。間歇投与法で も栄養状態は十分保たれているとの外来担当医師からの報 告もあり、夜間投与を積極的に取り入れる心゙きと考元られ た。

\section{表 1 指導内容}

(1)高カロリー輸液の必要性

(2)輸液バック・ラインの交換法

(3)交換時刻・終了時間

(4)交換時の消毒方法

(5)輸液ポンプの調整法

(6)カテーテル挿入部の処置・入浴時の処置

(7)カテーテルのヘパリンロック法

(8)トラブル発生時の早期察知と対応

(9)自己管理 : 輸液製剂の異常の有無、ポン プ充電、体温、尿量測定

(10)輸液製剂の保存法

(11)使用後の医療材料の処理法

\section{【結語】}

われわれの作成したH P Nシステムにおいて、安全性と 患者および家族のQＯＬが確立されていることが示された。 高齢者における H P Nのトレーニング効率を改善するかが、 今後の課題である。

図 1

$\times 10$

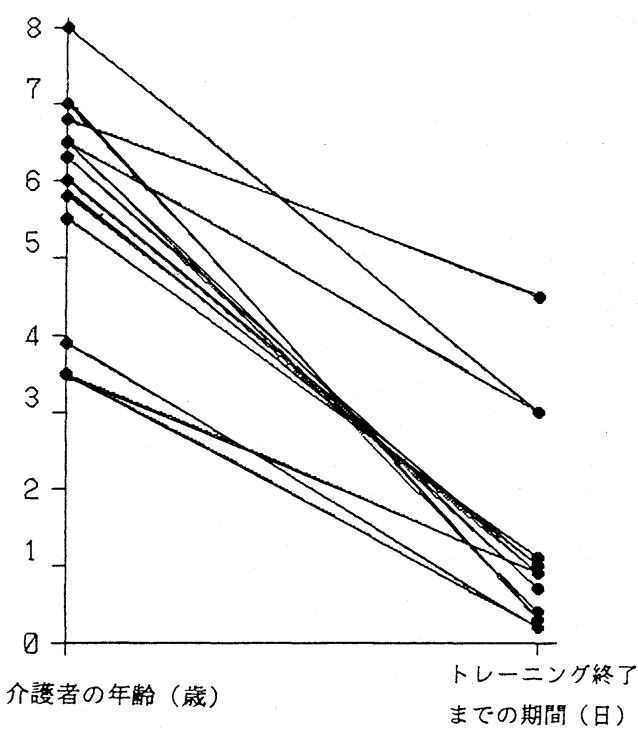

表2 退院指導におけるチェック項目

\begin{tabular}{|c|c|c|c|c|c|c|c|c|}
\hline & 項 目 & チェック内容 & 月 日 & 月 日 & 月 日 & 月 日 & 月 日 & \\
\hline 1 & 治療バック交換 & $\begin{array}{l}\text { (1)バックの刺入部を清拭し、セット先端を差し达む } \\
\text { (2)チューブ内にエアー入らないように施行する }\end{array}$ & & & & & & \\
\hline $\begin{array}{l}\text { 清 } \\
\text { 潔 }\end{array}$ & $\begin{array}{l}\text { チャンバー } \\
\text { セット交換 }\end{array}$ & $\begin{array}{l}\text { (1)セット内にエアーが入らないように治液を満たす } \\
\text { (2)セットをポンプにセッティングする } \\
\text { (3)治療速度のセッテイング } \\
\text { (4)セットの交換 }\end{array}$ & & & & & & \\
\hline 操 & $\begin{array}{l}\mathrm{I} V \mathrm{~V} \text { 挿入部 } \\
\text { の 清 掃 }\end{array}$ & $\begin{array}{l}\text { (1) I V Hチューブが抜けないようにハンザボアを剝 } \\
\text { がす } \\
\text { (2)イソジン綿棒で刺入部を清拭し、イソジンゲルを } \\
\text { 塗布する } \\
\text { (3)ハンザボアを貼用する }\end{array}$ & & & & & & \\
\hline 2 & $\begin{array}{l}\text { トラブルについ } \\
\text { ての理解と対応 }\end{array}$ & $\begin{array}{l}\text { (1)血液逆流、空気の誤入 } \\
\text { (2)治療ルートの污染 } \\
\text { (3游入速度の異常 } \\
\text { (4)I V Hチューブの抜去 }\end{array}$ & & & & & & $\begin{array}{l}\text { ○良 (理解度 OK、 } \\
\text { 技術マスター) } \\
\triangle \text { もう少し } \\
\times \text { 不良（再指導の必要 }\end{array}$ \\
\hline 3 & 自己管理ノート & $\begin{array}{l}\text { (1)尿糖の測定 } \\
\text { (2)体温、体重測定 } \\
\text { (3)治液バックの交換時間の記入 (残量の確認) }\end{array}$ & & & & & & \\
\hline
\end{tabular}




\section{$1 \mathrm{H} 21$ 癌末期患者の看護 〜 告知患者とその家族への援助〜}

厚生連鶴見病院看護科 阿南美津恵

\section{1 はじめに}

癌告知一これは現在の社会問題の一つである 。今年 5 月の新聞の厚生省の調査によると、 (1)告知したー18.2\%、(2)告知していない-81 .9\%、(1)のうち良かったー58.7\%、(2)のうち 察していたようだー $42.5 \%$ となっていた。今 回告知しない方針だったが、家族から患者へ 告知してしまった例を経験した。この例を通 して告知はどうあるべきか、医療者側の援助 のあり方を検討したので報告する。

2 患者一66歳 はっきりした性格

病名 - HCC LK

職業一民宿経営していたが現在生活保護

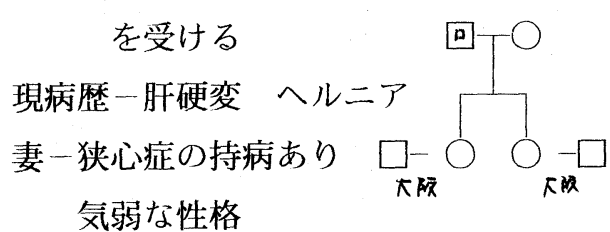

3 病状経過及び看護の実際

(1)入院から告知を受けるまで〜H 4.3.2右胸 水貯留LK疑いにて入院。持続ドレナージにて 胸水を排除していた。DrよりK氏には「胸に 水が溜まっている為管をいれてぬく」と説明 した。妻には「LKの疑いが強いが、今のとこ ろは胸水がひけば退院できる」と説明した。

以後のK氏は「拷問にあっているようだ。点 滴してもよくならん、何もせんでええ」等の 拒否の態度が見られた。熱発が続き諸症状モ でる為思うようにいかない病状に対し、いら つきを隠せない様子であった。Nsは訴えをよ く聞き、状態にあわせ言動に注意した。 (2)告知のとき〜一旦症状も落ちつき外来通院
していたがH 4.10.20、HCC 確定にて再入院 した。TAE 予定だったが、状態が悪く中止と なった。OPも危険なためPEIT施行。この頃、 妻は、Drより「肝細胞癌である。よくても2 年の余命だが、LKもある為恐ら 2 年は無理だ ろう」と告知を受けた。K氏には告知しない 方針とした。妻は衝撃を受けた様子だった。 K氏へは、「肝硬変が悪化したので治療する 」と説明した。K氏は、病状が悪化していく 事に不安と不満を覚えNs と妻に対し訴えが多 かった。妻は、K氏への説明や訴えの受け止 めにどうしていいか判らず毎日Nsに相談して きた。妻は、家庭の事情、家計問題、持病の 事等様々な悩みを抱えK氏に対しての困惑に 耐えられずH 4.11.1 Ns室に口論の末咄媄に 病名之予後を告知してしまったと言ってきた 。Ns、Dr共予期せ女事に戸惑った。カンファ レンスを重ね病名や病状については今までど うりの態度を取り続け、表情や言動に注意す る事にした。

(3)告知の後〜様々な不安や不満を訴えていた K氏が、癌と知らされた後は無口となり、NS が訪室してもじっとみつめるだけの日がつづ いた。不眠が続き、妻に「自殺したい」など と呟いていた様だった。妻は面会の度に泣い たり取り乱したりする為、妻の面会を制限す ることにした。K氏に対しては、訪室の機会 を多く持つようにし、精神的援助に努めた。 K氏は「もう何もせんでくれ」「後どれぐら い生きられるかな」等と言葉した。私たちは ただ“大丈夫ですよ”等の言葉しかかけるこ 
としかできなかった。K氏の状態も徐々に悪 化し、Dr、妻とも話し合い無理な延命はしな い方針とし、H 5.1月中旬頃個室に移った。 K氏は、以前より個室=末期と考えており個 室を拒否していたが、この頃より受容の態度 がみられるようになった。妻も受容の態度が

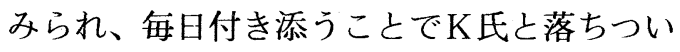
た時間が持てたようだった。その後、肝性脳 症、腹水増強等の症状が著しくなった時も、 K氏は「あんたらの顔を見るとほっとする。 先生に会いたい」と言うことが多かった。そ してH 5.2.15 永眠された。

\section{4 考察}

この事例は「病名告知」を「妻」が「攄に耐 えかねて」行ったものである。一般的に、告 知患者の反応として、キューブラ＝ロスによ

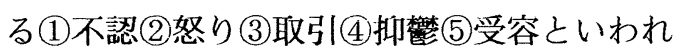
ている。又家族の心理として、(1)衝撃(2)防衙 的退行(3)承認(4)適応と示している。告知を支 えるターミナルケアとして医療者の役割には (1)延命医療(2)苦痛除去(3)望ましい死への援助 が挙げられる。又、医療者と共に極めて大き な役割を果たす家族には、(1)良い取え手(2)十 分な時間(3)日常的な話題(4)遺言の取え手とい った条件が備わっていると言われている。こ の事例を通して上記の概念を実感し経験でき た。特に家族に対しては、患者と同等もしく はそれ以上の配慮や援助が必要なことが判っ た。K氏の場合は、医療者は否定していたも のの妻から告知を受けたことで、抑斏状態は 更に強かったのではないかと思われる。妻の 場合も、咄嗟に口走ってしまったことで取り 返しが付かず、承認、適応に至るまで時間が かかった様だった。K氏の場合も告知しない 方針だったが、患者と妻の背景や心理などを もっと十分観察し察知すべきであった。
K氏に対して、告知後は否定も肯定もせず、 そっこ状態観察をし訴えをよく聞く態度を第 一とした。告知後、抑樫状態ではあったもの の最後には“ありがとう”の言葉も聞かれ、 特に取り乱すことがなかったことから考える と、この援助でよかったのではと考える。 5 まとめ

癌告欩の問題は奥が深く、どうあるべきか一 概にはいえない。しかし、どんな場合でも医 療者側は落ちついた態度で、患者や家族を尊 重しつつ、患者が予後をその人らしく生き、 やすらかな死を迎えることが出来、又家族も 満足出来るような夕ーミナルケアにすべきで ある。 


\section{$1 \mathrm{H} 22$ 癌性疼痛患者への鎮痛薬投与に関する看護婦の意識調査}

\section{○平山薰松本俊子江幡世利子}

総合病院土浦協同病院外科病棟

I はじめに

末期癌患者の $70 \%$ が主症状として痛みを体 験し、その50\%はかなり強い痛みであり、30 \%では耐え難いほど強いと報告されている。 しかし、当病棟の疼痛緩和ヶア（以下ヶア） 指示により鎮痛薬の投与をすることに終始し ている。をた薬剤量、投与回数、患者の状態 により、鎮痛薬投与の制限を余儀なくされ、 患者の苦痛を持続させていることがある。そ こで、実際に鎮痛薬を投与している我々看護 婦の意識調査を行い、問題点を明確にし、こ れまでのケアをふり返り、癌性疼痛患者のケ アに対する意識を向上させる目的で研究に取 り組んだ。

\section{II 研究方法}

1. 質問用紙によるアンケート調査

2 . 調査対象：西 4 階病棟看護婦全員( 23 名)

3 . 調査内容

(1)鎮痛薬投与の理想と現実、与薬をのばす 場合の理由

(2)与薬をのばした場合のケアの有無、内容 時間、効果について

(3)鎮痛薬の知識、与薬後の確認時期

(4) WH O方式癌疼痛治療法飞ついて

4.アンケート内容を集計し、結果にもとづ き分析、考察する。

III結果执よび考察

アンケート調查の回収率は $100 \%$ であった。 これを質問別に回答結果を集計し、分析検討 した。

(1)鎮痛薬投与の理想と現実、与薬をのばす 場合の理由（重複回答あり）

理想とする与薬法では、「予防的投与」が 14件（56\%）、「患者が希望すればただちに」 が 8 件 ( $32 \%)$ 、「最終的手段として」が 2 件 （ $8 \% ）$ と表1飞表わしているょうに、意見 が分散している。

\begin{tabular}{|c|c|c|c|c|}
\hline \multirow[b]{2}{*}{1.} & \multicolumn{2}{|c|}{ 理想とする与薬法 } & \multicolumn{2}{|c|}{ 実際の与薬法 } \\
\hline & 予防的投与 & 14件 (56\%) & 患者が希望すれば & 20 件 $(65 \%)$ \\
\hline 2. & 患者が希望すれば & 8 件 $(32 \%)$ & 予防的投与 & 8件 ( $26 \%)$ \\
\hline 3. & 最終的手段として & 2 件 $(8 \%)$ & 最終的手段として & 2 件 $(6 \%)$ \\
\hline 4. & $\begin{array}{l}\text { 患者、家族、医療者の } \\
\text { 話しあいのもとに }\end{array}$ & 1 件 (4\%) & ケースバイケース & 1 件 $(3 \%)$ \\
\hline
\end{tabular}

近年、癌疼痛治療の主軸は鎮痛薬であるとい ら認識が世界的に定着し、全国的にも予防的 使用が最良であるとされている。しかし、当 病棟で予防的投与を支持している看護婦は 56 \%にすぎず、現在最良とされている予防的与 薬法は、約 2 分の 1 の看護婦にしか受け入れ られていないのがわかる。実際の与薬法では 「予防的投与」は 8 件 ( $26 \%)$ と減少し、理 想と現実にギャップがみられる。また理想と する与薬法で「予防的投与」と回答した 14 件 のらち、実際では「看護婦の判断で与薬をの ばすことがある」と回答したのは11件(79\%) にも及んでいる。また「患者が希望すればた だちに」と回答した 8 件のらち、「看護婦の 判断で与薬をのばすことがある」と回答した のは 8 件 ( $100 \%)$ であった。「鎮痛薬投与 をのばしたことがある」と答えた者は、20名 (87\%)飞も達している。（図 1 ） 
このよらに、理想と現実の与薬法ではかなり の違いがあり、一様に実際には与薬をのばし ていることがわかる。

\begin{tabular}{|l|l|}
\hline \multirow{2}{*}{ ある } & \\
\cline { 2 - 2 } & 20 名 (87\%) \\
\cline { 2 - 3 } ない & 3名 (13\%) \\
\cline { 3 - 3 } &
\end{tabular}

図 1 看護婦の判断で鎮痛薬投与をのばしたことがあるか。

表 2 鎮痛薬投与をのばしたことのある20名に対して与薬をの ばす理由

(重複回答あり)

\begin{tabular}{|l|ll|}
\hline 1. & 前回与薬との間隔が短かすきる & 18 件 $(40 \%)$ \\
2. & 患者の一般状態が悪い & 14 件 $(31 \%)$ \\
3. & 医師の指示で回数が決まっている & 13 件 $(29 \%)$ \\
\hline
\end{tabular}

鎮痛薬投与をのばす理由は表 2 の順位になっ ている。鎮痛薬の副作用や依存性、患者の状 態、医師の指示が重視されているのがわかる。 「医視の指示で」と回答した者の中には、予 防的投与が理想だが、医師が実施していない ため、看護婦の独断では無理」という意見も あり、理想と現実、患者と医師の間で兴む姿 がらかが觉る。

(2)与薬をのばした場合のケアの有無、内容 時間、効果について（重複回答あり）

鎮痛薬投与をのばした場合、19名（95\%） の者が代わりに何らかのケアを実施している。 ケア内容は表 3 亿表わしているが、「何もし ない」との回答も1件（２％) あり、ケアに 対する認識の低さがらかがえる。1 回のケア 飞費やす時間（表 3 ）も、「訴えが治まるま で」と回答した者は 1 名（５％）にすぎず、 長時間痛みに苦しんでいる患者のことを扣も らと、ケアの時間としては短いと思える。 表3 与薬をのばした時、代わりに実施したケアの内容と時間

\begin{tabular}{|c|c|c|}
\hline $\begin{array}{l}\text { ケ } \\
\text { ア } \\
\text { 内 } \\
\text { 容. }\end{array}$ & $\begin{array}{l}\text { 1. マ.ッサージ } \\
\text { 2. 体交、体位のエ夫 } \\
\text { 3. 患者の話を聴く } \\
\text { 4. あん法 } \\
\text { 5. 湿布 } \\
\text { 6. のばした理由を説明 } \\
\text { 7. 何もしない }\end{array}$ & $\begin{array}{l}16 \text { 件 }(39 \%) \\
7 \text { 件 }(17 \%) \\
6 \text { 件 }(15 \%) \\
5 \text { 件 }(12 \%) \\
4 \text { 件 }(10 \%) \\
2 \text { 件 }(5 \%) \\
1 \text { 件 }(2 \%)\end{array}$ \\
\hline $\begin{array}{l}\text { ケ } \\
\text { ア } \\
\text { 時 } \\
\text { 間 }\end{array}$ & $\begin{array}{l}\text { 1. } 10 \text { 分 } \\
\text { 2. } 5 \text { 分 } \\
\text { 3. ケースバイケース } \\
\text { 15分 } \\
\text { 4. } 30 \text { 分 } \\
\text { 訴えが治まるまで } \\
\text { 5. 無回答 }\end{array}$ & $\begin{array}{l}5 \text { 名 }(26 \%) \\
4 \text { 名 }(21 \%) \\
2 \text { 名 }(11 \%) \\
2 \text { 名 }(11 \%) \\
1 \text { 名 }(5 \%) \\
1 \text { 名 }(5 \%) \\
4 \text { 名 }(21 \%)\end{array}$ \\
\hline
\end{tabular}

ケアの効果については、「多少軽減したと思
ら」13名（68\%）「効果のあるときもある」

2 名 $(11 \%)$ である。鎮痛薬投与以外のヶア では痛みは消失せず、補助的手段と考えられ る。

(3)鎮痛薬の知識、鎮痛薬投与後の確認時期 そついて

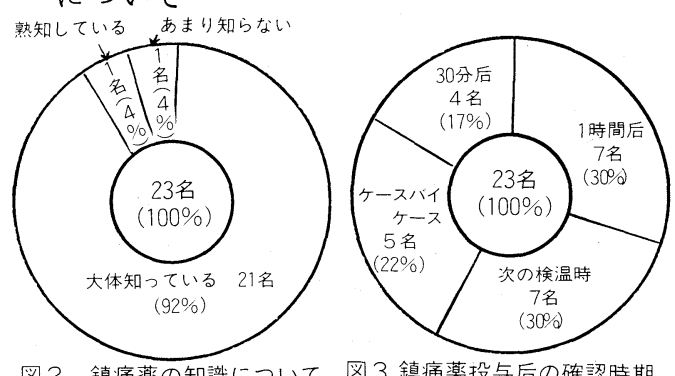
作用・副作用は「大体知っている」が92\%に 及んでいるにもかかわらず、確認時期に大き なバラッキがみられ、看護婦個人の判断力と 鎮痛薬投与に対する意識の違いが表われてい る。

(4) WH O方式癌疼痛治療法について


患者の看護を実施しているにもかかわらず、 結果からは癌性疼痛に対する関心の薄さがう かがえる。

\section{IV まとめ}

調査結果により、癌性疼痛患者への鎮痛薬 投与に関しての意識と対応には、看護婦個人 により大きな違いがあることがわかった。調 査を通して看護婦の認識の薄さ、知識不足が 明確にできたため、今後は学習会などを通じ て、鎮痛薬の知識と関心を深め、除痛に向け てょり良いケアが行えるようにしたい。 


\section{〔はじめに〕}

私は解地医寮のあるべき姿を求め続けて 22 年、この間、保健（福祉）と医㙩の合 体を目指す P P C 医潦に励んできた。即ち 住民教育と保煡をべースに、臨床面では病 院を家庭に持ち込めと「全村病院棈想」に よる在宅ケアに努めたが、著しい過疎化と 超高跉化に従い、疾病構造は一変し社会環 境は程済的、空間的、労力的に親扶養が不 可能な状態となり、集落即病院の“全村病 院構想”から、集落即老人ホームの“ケア 完備集落構想”へと発想転換を余儀なくさ れた。

経済優先社会の整害に気付き、金より心 を大切にする、人間自然の姿に戻り、医㙩 面でも医科学の粋を集めた延命医潦よりも、 Q O Lを求め、人権を守り、自然人間味溢 れる医潦を望む声が高まり、在宅ホスピス など私が提唱する满足死する医察そのもの となった。時を同じくして住民から終末期 医病宣言（Living Will）をして满足死 しようとの話が出て、“满足死の会”が出 来た経緯を報告し、皆様のご意見を仰き、 賛同者の入会をおすすめしたい。

\section{[本会発足の動機〕}

62才.男 脂卒中で倒れ 5 年近く植物人間 状態が続き、経済的、労力的な極限から家 庭崩䧇にまで至った例、55歳。男肺癌患者 の苦痛を見かねた家族が、安楽死を望むも 拒否され、相談に来られLiving Willの 話をしたのが発端だが、勿論、近年色々話 題になる瞱死、腃器移植、人工授精等の疑 問がからんでいることは事実。

\section{高知県 拳ノ川喰所}

正田善平

$$
\text { 【会のネーミングについて〕 }
$$

安楽死は一般によく知られた言葉ではあ るが、辞書によると、「死期の近い患者を 身体的精神的苦痛から救う目的で人為的に 安らかに死期を早める」とあり、殺人の危 険性が合まれ、宗教、道德、法律などの立 埸の問題から近年は安楽死なる語は使われ なくなった。

尊篇死は‘73年、アメリカ病院势会が 患者は思いやりあるケアを受ける権利や、 治療を拒む権利をうたい、・81年に世界 医師総会のリスボン宣言で、患者は医師を 選ぶ権利、治掌を拒む権利と尊綮ある死の 権利を出したあと、‘83 年アメリカで重 症ダウン患者の両親が、裁判所の許可のも と治㙩中止した時、初めて尊篇死なる言葉 が出来た。日本では翌 ‘ 4 年、東京宣言 で個人の尊厳を保つため自己決定梅を尊重 し、続いて'85年アメリカ政府が尊跾死 の権利を認め、人間として名誉を保ちなが ら死ねるようにすべきだとの考え方が広が るも、その人の名誉とかその人らしさを誰 が判断するのか? それが問題で、若し第三 者なら患者の自己決定権は薄れると思う。

ところが満足死は尊爰死よりも 4 年も前 （79 年）から私が提唱しているもので、 先づ本人の淦足、家族の渵足と医療チーム 全員が誠心誠意つくした満足感に加え、行 政の满足、即ち社会福祉の充実で独居老人 が安心して在宅死出来れば行政も满足出来、 続いて地域住民の满足、「あの方は幸せだ ったなあ。私も、この地であのような死に 方がしたい」と住民の評価とも言うべき住 民の满足、最後に司法の満足するものを 
“满足死”と言っている。

以上により安楽死は殺人性をはらむから ダメ。尊厳死は患者の主体性と自己決定権 〈あとがき〉

に乏しいし、終末期の患者の心理は実に微 妙で、尊爰が满足とはなり難く、又、新小 辞林にも無い程一般的でない。これに比べ、 满足は日常茶飯事に使う解り易い庶民的用 語で、满足死こそ患者主体で自己決定権を 尊重するものと考える。

近年医挜の反省からのiving Willだ が、これを楯に安易に流れ、患者不在の医 隐に陷らないよう、厳に注意を払いたい。 患者の本心を知ることは至難の技であり、 その心理は死の直前まで生」を求めたり、 「死」を受容したりとゆれ動くもの。宣言書 の要旨は会員証の重面参照。

〔おわりに〕

私は、壀地医势のるべき姿を求め、 $\mathrm{P}$ P Cを実践し、满足死する医療に励むうち、 がん末期の苦痛、ねたきり老人、植物人間 などをケアする時、在宅ホスピスを望む地 域住民の中から living Willの話が出て、 色々と討論の末、满足死の会を桔成したの で、皆様のこ意見を戴き、入会をお忤めす る。

\section{満足死（終末期医療）宣言書}

(1) 私が死の床につき死期が近いと診断された時は、いた ずらに死期を引き延ばすことは一切お断りします。

(2) ただし苦痛を和らげるための医療は最大限お願いしま す。

（3）また植物人間状態で、なお意識の回復の見込みのない 旨、2 名以上の医師によって診断され、かつ遺族の同 意のあるときは、一切の生命維持装置を止めて下さい。

以上は私の正常な精神状態の時宣言したものです。この 宣言に従って下さった時、全ての責任はこの私にあります。 


\section{腎・泌尿器疾患}

当院結石治療センターの活動

1 I09 一体外衝撃波尿路結石破砕と結石成因検査一

静岡県厚生連 静岡厚生病院 泌尿器科 $\mathrm{O}$ 松田忠久

検查科松場正明、仁科扶支子

看護部 松永揚子

[はじめに]

当院結石治療センターでは、1992 年 4 月

13 日より体外衝撃波結石破砕装置を導入し、 腎尿管結石の治療を行い、地域医療に貢献し てきた。また結石破砕治療のみでなく、結石 成因を明らかとし、再発予防に努めてきた。 当センターでの現在までの治療状況と結石成 因検查の結果について報告する。

\section{[対象]}

1992 年 4 月 13 日より 1993 年 5 月 31 日ま でに当センターにて腎尿管結石に対し、体外 衝撃波結石破砕術（E S W L ) の治療を受け た 197 症例（男性 149 例、女性 48 例）、240 結石であった。

\section{[方法]}

1) 体外衝撃波結石破砕装置は東芝製 $\mathrm{E} \mathrm{S}$ $\mathrm{L}$ - $500 \mathrm{~A}$ を使用した。この装置では圧電方 式により衝撃波を起こし、超音波断層法によ り術中も常に結石をモニタリングしつつ結石 を破砕できる。またoverhead applicator の採用にて、操作性が優れている。患者との 接触面はwater bagによるドライ方式とな っている(図1)。

治療は原則として入院で行ない、麻酔は特 に用いず、鎮痛坐剤および鎮静剤のみで行な った。治療中および治療後は点滴により利尿 を促し、尿はすべてペーパーフィルターを通 し、結石収集に努めた。

2) 結石成因の検索のため、血液検查およ び原則的には治療前 24 時間の蓄尿を行ない、 その生化学的分析を行なった。その結果より、 高尿酸血症、高尿酸尿症を診断した。さらに 尿中 $\mathrm{Ca}$ 排泄量 $5 \mathrm{mg} / \mathrm{Kg} / \mathrm{Day}$ 以上のものを 過 $\mathrm{Ca}$ 尿症として、 $\mathrm{Ca}$ 制限試験および $\mathrm{Ca}$ 負荷 試験を行ない、腎性過 $\mathrm{Ca}$ 㽷症、吸収性過 $\mathrm{Ca}$ 尿症およびその何れにも分類できないも のを中間型過 $\mathrm{Ca}$ 尿症とした。また症例によ り、 $\mathrm{N} \mathrm{H}_{4} \mathrm{C} 1$ 負荷試験を行なった。

\section{[結果]}

1) 197 症例 240 結石に対し E S W Lを 285 回 (平均 1.19 回) 施行した。240 結石のうち 225 結石は完全排石され $93.8 \%$ の完全排石 率であった。破砕効果がなく観血的手術や内 視鏡手術に移行したものは 1 例もなかった。 合併症は全例に血尿を認めたが、 1 例で 5 日 間続いた以外は $1 \sim 2$ 日で消失した。疼痛は 軽度で数例に鎮痛注射剂を要しただけであっ た。

197 症例中 140 症例では結石分析がなされ、 表 1 に示す結果であった。

2) 197 症例中 95 症例に結石成因と考元 られる延べ 130 原因が認められた（表 2 ）。

\section{[考察]}

日本に E S W L が導入され始めて 10 年が 経とうとしている。この 10 年間に機器の改 良および積み重ねられた症例により E S W L の適応も、初めに考光られたものより拡大し てきた。今回、当院結石治療センターでも国 産 E S W L装置を用い結石治療を行ない良好 な結果を得た。

E SWL 初期の段階では、Chaussy \& $S c h m i e d t$ は治療禁忌を表 3 に示すものと 
したが、現在ではこれらの症例もほとんどが E SWL治療が可能となっている。心臓ぺー スメーカー装着者も治療禁忌とされていたが、 現在では安全に治療が行なえることがわかっ ており、当センターでも 2 例の心臓ペースメ 一カー装着者に特に問題もなく治療が行なわ れた。以上より現在では表 4 に示すものが $\mathrm{E}$ SWL治療の禁忌と考えられている。

結石分析の結果ではシュ酸 $\mathrm{Ca}$ 単独結石と

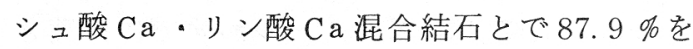
占め、他の報告と大差はなかった。ただし 1 例ケイ酸結石が認められた。結石成分による E S W L 治療の効率は、術中の術者の印象で は既に言われている通り尿酸結石は硬くShot 数が多くなる傾向があり、感染結石は比較的 軟らかく破研効果は良好であるように思われ た。

一般的には腎尿管結石は 5 年間に約 $30 \%$ が再発するといわれる。腎尿管結石の治療が E SWLにより根本的に変わってしまった現 在にあっても、結石治療の最終目標は再発予 防にある。その考光に基づき当センターでは 比較的頻度が高く、予防も可能と思われる結 石成因を対象とした検査を行なってきた。そ の結果では 197 症例中 82 例に代謝性成因を、 13 例にその他の結石成因と思われるものが 見いだされ、予想以上に高率であった。特に 尿酸代謝に関するものの割合が高く、現在の 食生活等の影響と思われた。成因と思われる ものについては、各々表 5 のごとく再発予防 を行なっている。これらの予防の効果につい ては未だ観察期間が 1 年以下と短く、今回は 報告できなかった。ただし結石の成因が判り、 その予防方法が行なわれようとも、患者自身 がその必要性を十分に認識し、継続していか ない限り効果は期待できない。当センターで
もそうした症例があり、残念である。 [おわりに]

197 症例 240 結石に対し E S W L 治療を行 ない9 \% \%を超光る完全排石率を得、重大な副 作用もなく非常に満足な結果を得た。ほぼ 総ての腎尿管結石症に対してESWL治療が 可能と思われ、引き続き症例を重ねていきた いと思われた。また結石成因の明らかなもの に対する再発予防効果についても観察期間、 治療継続症例数が增えた時点で報告する予定 である。

\section{図 1}
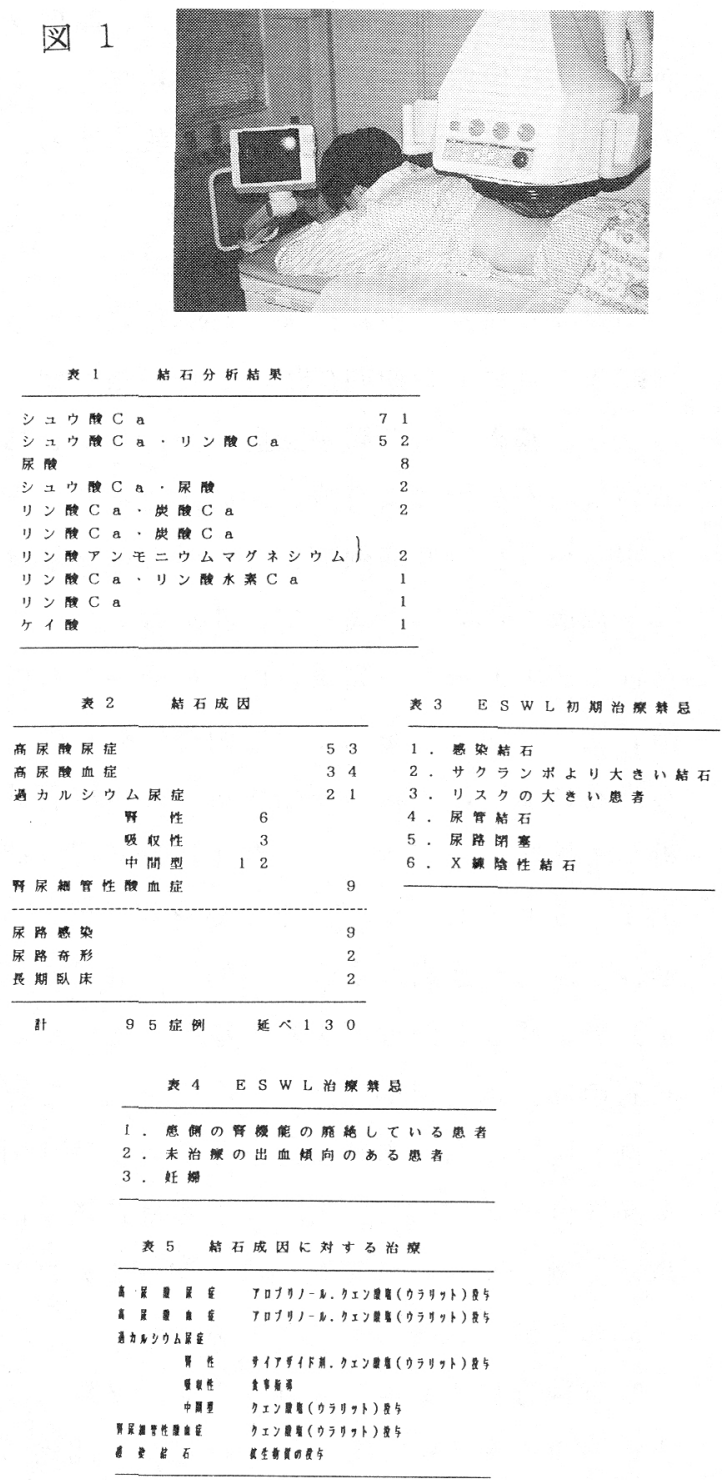


\section{$1 \mathrm{I} 10$ 高尿酸血症を伴う腎結石症に対するクエン酸製剤療法の検討}

\section{、西本憲治・丸山聡・安川明廣（尾道総合病院泌尿器科）}

1.はじめに

クエン酸カリウム・クエン酸ナトリウム ウラリットU $\left.{ }^{\circledR}\right)$ は、高尿酸血症に打ける酸性 尿の改善、アチドーシスの改善を目的とした 薬剂であり、尿 $\mathrm{pH}$ H昇することから尿酸、

シスチンを成分とした尿路結石の溶解剤とし て期待されている。今回われわれは、高尿酸 血症に伴う尿路結石症例に本剤を投与し、そ の有効性、安全性を検討したので報告する。

\section{2. 対象および方法}

(1)対象：対象は当科外来を 1988 年11月から 1992年 6 月までの期間に受診した腎結石症例 のうち、基礎疾患に高尿酸血症があるか、あ るいは結石分析により成分が尿酸であること が明らかな患者 9 症例である。対象の年齢は 33〜 72歳 (平均 54.8 歳) で、性別は男性 8 例、 女性 1 例であった。高尿酸血症に合併した腎 結石症例は症例 1 を除く 8 症例で、結石の自 然排石あるいは手術の既往がありその結石分 析が尿酸結石亡判明していた症例は 2 例（症 例 1、3）であった。KUBにてレントゲン透 過性を示した症例は 4 例（症例 $1 、 3 、 5 、$

7 ）で、残り 5 例は石灰陰影を有していた。 結石の部位は全例 $R_{2}$ 症例で、右腎 1 例、左腎 5 例、両腎 3 例であった。結石数は 1 個 4 例、 多発 5 例であった。結石の大きさは長径 $4 \mathrm{~mm}$ 以下 1 例、 $5 \sim 10 \mathrm{~mm} 4$ 例、11 20 $\mathrm{mm}$ 例、 21 〜30 m 2 例、41〜50 mm 1 例であった。

(2)試験方法：クエン酸カリウム・クエン酸 ナトリウムを $3.0 \mathrm{~g} /$ 日の経口投与から開始し、
その後尿 $\mathrm{pH}$ 変化と副作用を観察し、効果不 十分例では適宜 $6.0 \mathrm{~g} /$ 日まで増量した。治療 期間は 2 力月から19力月で、平均 12.8 力 月で あった。併用薬剤として 3 例（症例 4、6、 8 ）に拈いてアロプリノールがすでに投薬さ れており、2 例（症例 $3 、 5$ ）に対して今回 の検討と同時にアロプリノールの投薬を開始 した。また、症例 4 については合併していた

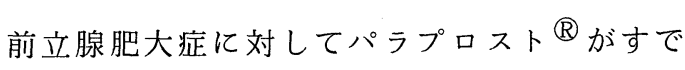
に投与されていた。

\section{(3)観察項目・効果判定: 本剂投与前に尿}

$\mathrm{pH}$ 、血中尿酸値を測定し、投与後は尿 $\mathrm{pH}$ 受 診每に、血中尿酸值は原則として投薬開始 4 カ月目に测定した。結石の溶解程度について は $\mathrm{KUB} ・ \mathrm{IVP} 、 \mathrm{CT}$ 、超音波検査のいずれかの 検査あるいは複数の検查を併用しつつ、原則 として 3 力月毎に結石の大きさを計測し、完 全溶解、部分溶解、不变、增大の 4 段階飞効 果判定した。副作用については自覚症状の問 診を行い、安全性を判定した。

\section{3. 結果}

(1)血中尿酸值については本剂投与前が 6.5 $\pm 1.3 \mathrm{mg} / \mathrm{dl}$ であるのに対し、投与後 4 力月 目は $5.9 \pm 1.4 \mathrm{mg} / \mathrm{dl}$ とやや低值であった。

(2)尿pHの変化については本剤投与前、投与 後 2 週目（一部の症例に扔いては 1 週目ある いは 4 週目)、3 月目、 6 力月目の測定值 を検討対象としたが、それぞれ、 $5.8 \pm 0.6$ 、 $6.6 \pm 0.6 、 6.7 \pm 0.6 、 6.6 \pm 0.7$ であっ た。 
個々の症例のpHの変化については投与前と 投与後 2 週目、 3 力月目、 6 力月目の 3 回の 平均値を比較した。尿 $\mathrm{pH}$ 的 1.0 以上上昇した 例は 4 例、 $0.5 \sim 0.9$ 上昇した例 3 例、0〜 0.4 上昇した例は 2 例であった。

(3)結石溶解については 2 例（症例 1、3） において完全溶解を認め、完全溶解までの期 間はそれぞれ15力月、 2 力月であった。1例 （症例 5 ）は投薬開始17力月経過し、現在も 加療中であるが、徐々に結石は溶解しつつあ り部分溶解と判断した。残り 6 例は 5 から 19 力月、平均 13.5 力月投薬したが溶解を認めず、 不変と判定した症例が 5 例、また、結石が増 大した症例が 1 例あった。完全溶解の 2 例と 部分溶解の 1 例の結石の大きさはそれぞれ25、 25、46 mm と大きな結石でKUBにていずれあレ ントゲン透過性であった。すなわち、レント ゲン透過性結石 4 例中 3 例 $(75 \%)$ が溶解を 示し、一方、レントゲン非透過性結石 5 例は 全例溶解しなかった。

完全溶解の 2 例之部分溶解の 1 例の合わせ て 3 例の尿 $\mathrm{pH}$ 推移をみると投与前、投与後 2 週目、 3 力月目、 6 力月目の测定值はそれ ぞれ $5.2 \pm 0.3 、 6.5 \pm 0.9 、 7.0 \pm 0.0 、 5.8$ \pm 0.4 であった。不変、増大の 6 例の測定值 $6.1 \pm 0.4 、 6.6 \pm 0.5 、 6.6 \pm 0.7 、 6.9 \pm 0.5$ 之比較すると、有効 3 例では本剤による尿 $\mathrm{pH}$ の上昇幅が大きい傾向があった。

完全溶解、部分溶解の 3 例の血中尿酸值に ついては投与前と投与後 4 力月目の測定值は それぞれ $7.5 \pm 1.3 、 4.6 \pm 0.8$ であった。 不 変、増大の 6 例の測定值はそれぞれ $5.9 \pm$ $1.0 、 6.6 \pm 1.2$ であり、有効 3 例において は尿酸值の低下が著明な症例であった。

(4)副作用 - 合併症：本剂の投与中、副作用 を認めた症例はなかった。

\section{4. 考案}

尿路結石症の治療については泌尿器科学的 内視鏡、結石破砕装置などの進歩にとあない 大きく変化したが、尿酸を成分とする結石は 硬いため、結石を砕き摘出するてれらの方法 では容易には破砕されず残石のできる頻度む 高い。一方、尿をアルカリに傾けると尿酸結 石は溶解することが知られており、このよう な結石に対しては化学溶解療法が第一選択と されている。今回われわれは、高尿酸血症を 伴う腎結石 9 症例に対し、クエン酸カリウム ・クエン酸ナトリウムを用いて尿のアルカリ 化を行い結石の溶解を試みた。

対象症例の結石成分は、4 例はレントゲン 透過性で結石成分は尿酸と思われたが、他の 5 例についてはレントゲン透過性でないため 少なくとも純粋の尿酸結石ではないと考えら れた。

臨床効果については、本剂投与により全例 に打いて尿 $\mathrm{pH}$ 年昇し、上昇の程度は投与後 2 週目以後はほぼ一定であった。その結果、 成分が尿酸と考えられた 4 例のうち 3 例が溶 解を認めた一方、単に高尿酸血症に合併した 腎結石の 5 例は結石溶解を認めず、結石溶解 には純粋な尿酸結石である必要があると思わ れた。乙の場合、血清尿酸值の低下、尿 $\mathrm{pH}$ 十分な上昇などの条件が必要であることあ今 回の検討で示唆されたが、少数例の検討であ るためてれらの点については今後症例を重ね る必要があろう。

本剤使用に打いて副作用、合併症の明らか なものは認めず、クエン酸カリウム・クエン 酸ナトリウムは安全性の高い薬剤之思われた。 


\section{$1 \mathrm{II1}$ 当センターにおける前文腺挨猃について}

\section{○茂木 佳江}

久末 百合子

\section{I ・はじめに}

当センターでは、AMH T S システムによ る総合検浐を実施している。平成 3 年 9 月よ り、50才以上の希望者に対して、排尿障害 についての問診・直晹䧐・前立腺特異抗原 以下PSA）を合せた前立腺挨診を行なって いる。受診者の寒態把握と、今後の前立腺娭 診のあり方を検討する為に、調查を行なった のでここに報告する。

\section{II . 調查対象と方法}

平成 3 年 9 月より平成 4 年 8 月までに前立 腺検殓を受けた $2 ， 227$ 名を、年令別一 5 0〜 59 才・ $60 \sim 69$ 才・ 70 才以上一と 職業別一農業従事者（以下農）・非農業従事 者 (以下非農) 一に分け、受診状況及び、前 立腺肥大の程度（注 1) と症状〈夜間頻尿 注 2）・腹圧排尿〉との関連を比較検討し、 又、精密検查結果（注 3 ）についても検討し た。

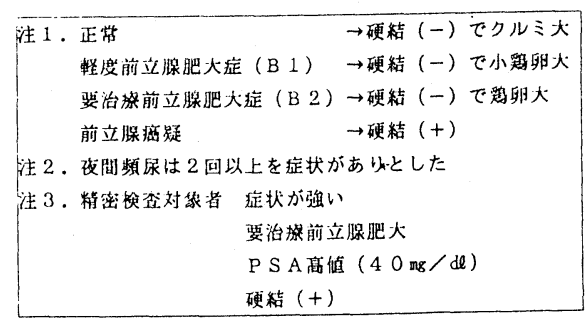

III. 結果

1. 前立腺険診の受診率は 54 . 4 \% であり 、精検受診率は 59 .2\%であった。いずれ も、年令とともに高率になっていた。又、職 業別では農が非農に比べ、受診率・精检受診 率とも高率であった。（表 1$)$

2 . 前立腺肥大の程度と症状では、夜間頻尿
小林 礼子鉿木 澄江

八百坂透（札幌厚生病院健晾センター）

兼田達夫（同泌尿器科）

の症状がある者は、正常者で277名（13 . $2 \%$ ) で、B 1・B 2では 154 名（28 ・4\%)であった。年令別では、加令ととも に症状がある者が多く、特に 70 才以上では 過半数を占めていた（図1)

腹圧排尿については、軽い腹死排尿がある 者は、正常者で620名 $68.8 \%)$ で、 B 1・B 2 では 206 名 (38.0\%) であ り、各年代ともほぼ同率であった。強い腹圧 排尿がある者は、正常者で 22 名 (1.4\% ) で、B 1・B 2では 17 名 (3１１\%) で あった。(図 2)

以上のことから、前立腺肥大症のものは、 正常者に比べ、夜間頻尿・腹圧排尿のある者 が多かった。（P<0．０1）

3. 精密検査結果内訳 (表 2 - 表 3 )

(1) 精密検查対象者 380 名中225名（5 9.2\%) が受けた。その結果、前立腺肥大 153 名 $(68.0 \%)$ : 前立腺癌 13 名( 5 . $8 \%$ ）・その他 44 名 (19.6\%) • 異常なしは18名（８．％）であった。 (2) P S A 高值者は42名で、7名が精検末 受診者であった。又、精密検查を行なった 3 5 名中、1 7 名は病理組織検查を受け、前立 腺癌が 13 名発見され、70才以上が過半数 を占めていた。

（3）非農は農に比べ、又、年令が若い结ど精 険受衫率が低かった。その為、前立腺肥大・ 前立腺癌などの発見率も低かった。

IV. 考察

前立腺检部受診率及び精检受部率は、加令 
とともに、又、農業従事者に多く、その関心 の高さが、うかがわれる。今後、未受診者の 疾病の早期発見の意味からも、㛟警の必要性 についての理解をはかり、受㟝衔奖をしてい きたい

前立腺肥大の程度と症状より、夜間頻尿で は、前立腺肥大の程度と関係があるが、正常 群でも、加令とともに症状がある者が多くな ることから、肥大症以外の要因も示唆された 。又、腹圧排尿は、要治療前立腺肥大症との 関連が認められた。

P S A は、前立腺瘦をスクリーニングする 上で、大変有効である事を再認識した。この ことからも、病理組織検查を受けていない 1 8 名と、精検末受診者の 7 名の中に、前立腺 癌が発見される可能性があると䉥念する。

当センターの前立腺癌の発見率（対前立腺 検診受診者）は、50才代で 0.15\%、6 0才代で0.39\%、70才代では 7.50

\begin{tabular}{|c|c|c|c|c|c|c|c|c|c|}
\hline \multicolumn{10}{|c|}{ 精密松盃粘果内訳（表 2) } \\
\hline & \multicolumn{4}{|c|}{ 䖪 } & \multicolumn{4}{|c|}{ 非䀼 } & \multirow{2}{*}{$\begin{array}{l}\text { 合 計 } \\
\quad(\%)\end{array}$} \\
\hline & \multicolumn{3}{|c|}{$50 \sim 5960 \sim 6970 \leqq$} & \multirow{2}{*}{$\frac{\text { 計 }}{15}$} & \multicolumn{3}{|c|}{$50 \sim 5960 \sim 6970 \leqq$} & 計 & \\
\hline 㟟裳なし & 4 & 9 & 2 & & 2 & 0 & 1 & 3 & $18(8.0)$ \\
\hline 前立腺肥大䄳 & 16 & 68 & 17 & 101 & 18 & 26 & 8 & 52 & $153(68.0)$ \\
\hline 前立 & 1 & 3 & 6 & 10 & 1 & 0 & 2 & 3 & $13(5.8$ \\
\hline その他 & 3 & 10 & 7 & 20 & 12 & 10 & 2 & 24 & $44(19.6$ \\
\hline
\end{tabular}

\begin{tabular}{|c|c|c|c|c|c|c|c|c|c|}
\hline \multirow[b]{3}{*}{ 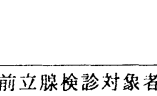 } & \multicolumn{4}{|c|}{ 農 } & \multicolumn{4}{|c|}{ 非震 } & \multirow[t]{2}{*}{ 合 計 } \\
\hline & \multicolumn{3}{|c|}{$50 \sim 5960 \sim 6970 \leqq$} & \multirow{2}{*}{\begin{tabular}{|c|} 
計 \\
1,778 \\
\end{tabular}} & \multicolumn{3}{|c|}{$50 \sim 5960 \sim 6970 \leqq$} & \multirow{2}{*}{\begin{tabular}{|c|} 
計 \\
2,318 \\
\end{tabular}} & \\
\hline & 975 & 704 & 99 & & 1,763 & 493 & 62 & & 4,096 \\
\hline 受部者: & 569 & 481 & 67 & 1,117 & 783 & 287 & 40 & 1,110 & 2,227 \\
\hline 受衫率 & 58.4 & 68.3 & 67.7 & 62.8 & 44.4 & 58.2 & 64.5 & 47.9 & 380 \\
\hline 精密狁查対象者 & 61 & $\begin{array}{lll}1 & 2 & 7\end{array}$ & 35 & 223 & 81 & 63 & 103 & 157 & 380 \\
\hline 受䇏者 & 24 & 90 & 32 & 146 & 33 & 36 & $\begin{array}{lll}1 & 0 \\
\end{array}$ & 79 & 225 \\
\hline 受路率 & 39.3 & 70.9 & 91.4 & 65.5 & 40.7 & 57.1 & 76.9 & 50.3 & 59.2 \\
\hline " 未受缷者 & 37 & 37 & 3 & 77 & 48 & 27 & 3 & 78 & 155 \\
\hline " 未受沴胙 & 60.7 & 29.1 & 8.6 & 34.5 & 59.3 & 42.9 & 23.1 & 49.7 & 40.8 \\
\hline
\end{tabular}

\begin{tabular}{|c|c|c|c|c|}
\hline \multicolumn{5}{|c|}{ P S A 高侹症例 表 3} \\
\hline P S A 高傎者 & 9 & 19 & 14 & 42 \\
\hline 解立腺嵒 & 2 & 3 & 8 & 13 \\
\hline 精検末受部者 & 2 & 5 & 0 & 7 \\
\hline
\end{tabular}

\%と、全国平均を上回っている。これは挨沴 開始 1 年目ということで高い発見率になって いることが考えられる。

精密険査結果より、精検受診者の過半数に 種々の疾病が発見された。しかし、精検受診 率は低く、とりわけ50才代では $40.1 \%$ と低いにもかかわらず、前立腺癌が 2 名発見 された。これをふまえ、今後は未受診者への 啓発をうながしてゆきたい。

V.おわりに

本研究を通して、前立腺険診が、他の成人 病検診に比べ、いまだ受部者に浸透していな いことを感じた。前立脉癌の発見率が高いに もかかわらず、検診の受診率・精密検查の受 診率が低いので、今後、保健婦業務を通して 、検診の必要性を理解してもらう為の㗢きか け、要精挨者への適切な医療機関の紹介・未 受診者への受訩勧奖、そして事後管理を徹底 してゆきたい。
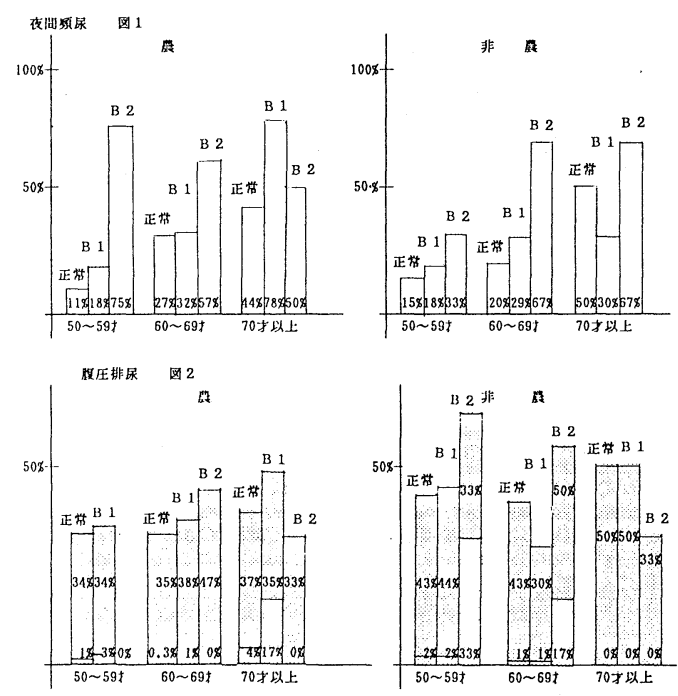
尿失禁流、患者にとって肉体的にも精神的 にも非常に苦痛を与えるものであり、その治 療法として各種菜物療法や手術療法が行われ ているが、尿道括約筋の機能的、器買的障害 に基ずく尿失禁の治療は困難である。今回我 々はTUR-P後の尿失禁に対して人工尿道括約 箭であるAMS800の掼え込み戒を施行し良好な 成續をえたので報告する。

虫者は72才の男性で、BPHにて平成3年3 片27日にTUR-P索施行したが、術後尿失禁状 態が出現した。尿道鏡にて前立腺の右側分特 によく切除されており、括約筋は見られるが 十分閉塞せず、TUR-Pによる括紷筋損賃と診 断した。退院後覀者沽常におしめを当ててい ないと生活出来ない状態であり、1時間パッ ドテストでも尿失禁量108gと高度で、患者は 尿失禁の手術を希望した。術前のCO cystometoryでは、膀胱容量369m1であるが、 これ以上のC0 注入では、気体の漏れが生じ

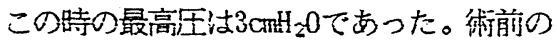
uroflowmetoryではvoiding volume $321 \mathrm{ml}$ @max $15.1 \mathrm{~m} 1 / \mathrm{s}$ 、残尿は見られなかった。 これらより患者はDARで腹圧排尿をしており、 DARの原因をD出による神経固性膀光光と考えた。 術前のurethral pressure profileでは、 maximun urethral closure presure (MUCP) 汁6 $\mathrm{cmH}_{2} 0$ 0でり括約筋不全を示していると思

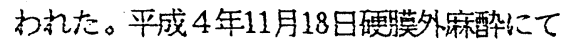
AMS300の球部尿道への植え込み術を施行した。 45mのcuffを選び、この時のbaloon圧を61-
○高村真一

（愛知県厚生連 海南病院）
$70 \mathrm{cmH} \mathrm{H}_{2} \mathrm{O}$ 亿調節した。pumpは尿道海綿体周囲 の創治瘾の阻害を起こさないように2ヶ月間 deactivationとした。術後経過沽良好であっ た。街後 2 ヶ月でpumpをactivationとした。


たのに対し術後は $72 \mathrm{CmH}_{2} \mathrm{O}$ と上昇した。手術

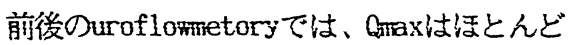
变わらずcuff装着による尿道抵沉の增大活ほ とんどないものと思われた。また術後の残尿 没術前と同樣なかった。街後の1時間パッド

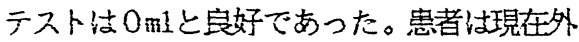
来通院中である

考察

A4S800人工录道括約箭拄 1973 年にBrandly Scott.H.Dにより開発されその後改良を重ね て現在使用されているモデルへと発展した。 馬場らの報告によるとこの括紷筋の植え远

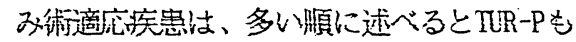
含め大前立腺肥大症手術後、前立腺䆓術後、



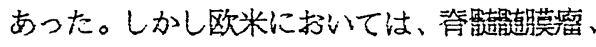



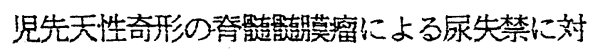
する括約筋植え达み術が多いの力将徴である。 cuffのインプラント部位としては、傽桄项部 と尿道球部の 2 力所があるが、傽光光致部が括 約笳括入部として洨最適と言われている。そ の理由としてSchreiterらは、尿道球部に cuffをインプラントした場合、cuffによる糜 䑌の発生率か高いことと、座位での圧白によ 
り Cuffが擷傷し尿漏れが発生しやすいことな どを挙げている。しかし以前の手術による瘾 着及び手划しんし的うなどを考えると尿道球 部への埋め达みが多くなるものと思われる。 そこでSchreiterらは、これらの欠点を補う ためcuffのインプラント部立をなるべく近位 部で会陰部樑く pelvic diaphragma近くに設 定することを鹳为ている。Fur1ow and Scottらの報告では、男性の70\%で原道球部 に埋め迈まれているが、日常生活には支障が ないと述へており、我々の症例でも尿道球部 を選抧した。括䄪筋括入後の尿失禁改善度に ついて沽Furlowらが109例について報告して いるが、83.5\%で完全に尿禁制が保たれてお り、また多少の尿漏れが見られるも生活にさ したる支障がない $9.2 \%$ 加えると $92.7 \%$ の 害者汃满足しており、尿失禁に対する治療法 として、この括約筋埋好込み術は、他こ類を 見ない好成績を挙げている。しかし機械的卜 ラブルによる尿失禁の再発も時々祘告されて おり、我々の症例も十分な経過䚁察が必要と 思勀炛た。

結語

我々洁TUR-P後の尿失禁に対してAHS800の 括入を行い良好な成績を得たので報告すると 共に若干の考察を加えた。 
$1 \mathrm{I} 13$

\section{前立腺癌における前立腺全摘術}

$の$ 䁂 床 検討

○和久井守

\section{【緒言】}

わが国での前立腺癌療法は、進行癌の比率 が高く心血管系の合併症が少ないこともあっ て内分泌療法が広く行われている。しかし、 内分泌抵抗性癌や再燃癌に対しては有効な療 法がなく予後は不良である。近年は早期癌に 対する前立腺全摘は当然のこととして、局所 進行癌に対してもその適応を拡大した集学的 療法が検討されている。われわれも臨床病期 $\mathrm{B} \sim \mathrm{D}_{2}$ にわたって前立腺全摘術を施行して いるので成績を報告する。

\section{【対象】}

当科で 1987年11月〜1993年 4 月に病理学的 に前立腺癌と診断され、臨床病期 $\mathrm{B} \sim \mathrm{D}_{2}$ で 重篤な合併症のない13例（B 9、C 3、D 2

\section{1 ）を対象に恥骨後式前立腺全摘術を施行し} た。症例の年齢は63〜 73歳、平均67.8歳であ った。術後観察期間は 2 か月〜 5 年 7 か月、 平均 1 年11か月であった。

\section{【方法】}

6 例はNeoad juvant 療法として $1 \sim 2$ か月 の内分泌療法を行った。他の 7 例は前治療な く全摘術を施行した。術式は全て恥骨後式で 行い、骨盤リンパ節郭清も併施した。術後診 断でリンパ節陽性と断端陽性例には内分泌療 法を追加した。

\section{【成績】}

\section{1 ）手術成績}

手術時間は 3 時間 50 分〜 6 時間 5 分、平均 4 時間 30 分、出血量は $1000 \sim 3200 \mathrm{~m} 1$ 、平均 $1580 \mathrm{~m} 1$ であった。勃起神経の保存は 3 例で可
寿美周平

(総合病院取手協同病院泌尿器科)

能であった。術後のカテーテル留置期間は 14〜 141日、平均34.8日、ただし最長日数の 1 例を除くと平均20.5日であった。

手術合併症は膀胱直腸瘻が 1 例 (No.11) に 見られたが、直腸浸潤 (pT4) を伴ったためで あった。カテーテル長期留置で瘻は閉鎖し た。尿失禁は 3 か月以内に軽度ないし消失し て 1 年後までに完全に消失するが、1 例 (No.

11)では 1 年以上続いている。

2 ) 臨床病期と病理学的進展度

局所進展度の正診率は、Bで $3 / 9$ 、C で 2/3、Dで1/1 であった。リンパ節転移は B で2/9、Cで2/3 に認めた。

\section{3 ) 予後}

術後観察期間は短いが断端陽性例も含めて 全例が再発の徵候なく生存している。

\section{【考察】}

術式は、䎵骨後式が同時に骨盤リンパ節郭 清を行えるので合理的なものといえる。われ われもこの術式によった。手術時間、出血量 は本邦の報告に近似していると思われた。手 術合併症は重篤なもので膀胱面腸瘻が 1 例に みられた。術後 3 週でカテーテル抜去時に造 影で明らかになり、カテーテル長期留置によ つて治癒した。病理学的には直腸浸潤 $\mathrm{pT}_{4}$ が 認められた。術後の尿失禁は、1例を除いて 3 か月以内にごく軽度となり 1 年後には完全 に消失している。局所進展が進むほど、尿失 禁の程度は重くなる傾向があった。これは膀 胱頸部と尿道遠位側の保存が困難になるため である程度避けられないものかもしれない。 
尿道狭窄は軽度でブジーで対処できた。

臨床病理と病理学的進展度は、局所とリン パ節転移ともに、臨床病期の方がunder diagnosisになることは今回の検討でも確認され

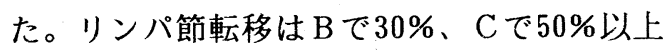
とされるがわれわれの成績も同様であった。 局所進展度の正診率は諸家の報告よりも低か った。

前立腺癌に対する手術療法はいまだ一定の 見解がない。臨床病期診断の信頼性が低いこ と、術後の尿失禁やインポテンスの恐れ、一 方、内分泌㞠法や放射線療法がある程度有効 であることなどが主な理由と思われる。今回
の検討でも術後病期が進行している例が多く 内分泌療法を追加した。しかし、内分泌、放 射線療法の長期予後には限界があり、手術療 法の再検討をすべき時期であると考えられ る。今回の検討では観察期間が短いため、長 期予後は言及できないが短期には良好な経過 である。

同じ内分泌療法を受けている患者でも、手 術をうけた患者は前立腺を切除されて担癌状 態ではないという意識のためか、前向きの明 るい印象をうける。完全切除が最上である か、その大部分を切除できる次善の手術で も、患者へのメリットはあると思われた。

表. 前立腺全摘症例 (1987.11 1993.4)

\begin{tabular}{|c|c|c|c|c|c|c|c|}
\hline 症例 & （歳） & 臨床病期 & $\mathrm{p} \mathrm{T}$ & $\mathrm{pN}$ & 術後病期 & 術後机モ療法 & 予後 \\
\hline 1$)$ & 71 & B & 3 & 0 & $\mathrm{C}$ & - & $67 \mathrm{~m} . \mathrm{NED}$ \\
\hline 2 ) & 72 & B & 2 & 0 & $\mathrm{~B}$ & - & $65 \mathrm{~m} . \mathrm{NED}$ \\
\hline 3 ) & 63 & B & 3 & 1 & $\mathrm{D}_{1}$ & + & $33 \mathrm{~m} \cdot \mathrm{NED}$ \\
\hline 4) & 68 & B & 3 & 0 & $\mathrm{C}$ & - & $26 \mathrm{~m} . \mathrm{NED}$ \\
\hline 5$)$ & 67 & B & 3 & 0 & $\mathrm{C}$ & + & $24 \mathrm{~m} \cdot \mathrm{NED}$ \\
\hline 6$)$ & 68 & B & 3 & 1 & $\mathrm{D}_{1}$ & + & $21 \mathrm{~m} . \mathrm{NED}$ \\
\hline 7$)$ & 65 & B & 2 & 0 & $\mathrm{~B}$ & - & 14 m. NED \\
\hline 8$)$ & 71 & B & 3 & 0 & $\mathrm{C}$ & + & $6 \mathrm{~m} \cdot \mathrm{NED}$ \\
\hline 9 ) & 67 & B & 2 & 0 & $\mathrm{~B}$ & - & $5 \mathrm{~m} . \mathrm{NED}$ \\
\hline 10) & 64 & $\mathrm{C}$ & 3 & 0 & $\mathrm{C}$ & + & $16 \mathrm{~m} . \mathrm{NED}$ \\
\hline 11) & 68 & $\mathrm{C}$ & 4 & 2 & $\mathrm{D}_{2}$ & + & $15 \mathrm{~m} . \mathrm{NED}$ \\
\hline 12) & 68 & $\mathrm{C}$ & 3 & 1 & $\mathrm{D}_{1}$ & + & 2 m. NED \\
\hline 13) & 69 & $\mathrm{D}_{2}$ & 3 & 2 & $\mathrm{D}_{2}$ & + & 2 m. NED \\
\hline
\end{tabular}


前立腺全摘出術後の看鿁

一尿失禁に対する援助を試みて一

○立蔵政子 加賀裕子 酒井紀美代

（札幌厚生病院泌尿器病棟）

I はじめに

近年、わが国における前立腺癌の発生率は 高齢化や生活の欧米化により增加の傾向にあ る。当施設でも早期前立腺癌の根治術として 前立腺全摘出術が行われるようになり、その

現在の医療において、疾患の治療ばかりでな くQOL。を高めることは看菨における重要な 役割である。そこで今回、本術後の尿失禁に 伴う不快感を軽減できるよう工夫し、またコ ンチネンスを目指し意欲的にとりくむことが できるよう援助を行ったので、その過程を報 告する。

\section{II 研究期間}

平成 4 年 8 月 24 日から平成 4 年 9 月 12 日

\section{III患者紹介}

K氏 68歳 無職 (元公務員) 性格: 温厚 病名 : 前立腺癌

家族: 妻と 2 人暮らし

IV入院から現在までの経過

平成 4 年 7 月 13 日、経尿道的前立腺電気切 除術施行。病理の結果、前立腺癌 (Stage A) と診断。「このまま放っておくと悪性になる」 と説明あり、「悪い物なら早く手術して欲し い。」と同意し、平成 4 年 8 月 3 日、前立腺全 摘出術施行となる。手術後は順調に創治癒し 3 週間後の 8 月 24 日、バルンカテーテル抜去 となる。

\section{$\mathrm{V}$ 看護の展開}

〈問題点〉

\section{1.尿失禁により陰部が不潔となる}

\section{2.寝具污染を心配し安眠できない}

\section{〈看膵目標〉}

尿失禁による不快が軽減される

\section{〈実施と評価〉}

暑い時期であり、常時オムツ装着に伴う発 汗と尿污染による不快に対して 1 日 1 回シャ ワー浴と、毎朝自己清拭を行った。これらの 事は爽快感が得られたとともに陰部の清潔保 持に有効でありオムッかぶれを防止すること ができた。

下着はゆとりのあるパンッをはく習慣だっ たが、オムツがずれて尿が横もれしてしまう ため、プレスネットをパンッ型に縫い使用し た。その結果、オムツの固定が良く横もれ防 止につながり、使い心地が良いと喜ばれた。

夜間熟睡してしまうと失禁量が多くても気 づかず、寝具を活すのが心配との声が聞かれ た。ベッド上に紙製のシートを敷いたところ 「污しても捨てればよい」ということで安眠 が得られた。

\section{〈問題点〉}

尿失禁があることで今後の生活に不安を抱 いている。

\section{〈看護目標〉}

\section{1.早期に尿失禁が改善される}

2.コンチネンスを目標に意欲がもてる

\section{〈実施と評価〉}

尿失禁を改善するのに骨盤底筋訓練が有効 であると言われている。方法は様々だが、毎 日行うことが大切であるため、簡単かつ確実 に行えるよう、「おならを我慢する感じで肛 
門を楴める運動を朝晚ふとんの中で 5 分する」 と説明した。

この訓練に加え、膀脳神経に作用する内服薬 が効を奏し、少しずつ尿失禁が改善されてい つた。（表 I )

尿失禁が始まってからもイライラすること はなかったが、「なかなか良くならないなあ」 と気落ちしている様子がみられた。尿失禁は すぐには止まらず、 1 週間後、 2 週間後とい うように長い目でみていき、あせらないよう 励ました。さらに、大半の患者が入院中に尿 失禁が止まるか、かなり量が減って退院する 事を説明した。

失禁量の测定は患者自身に行ってもらい、一 覧表に記入していったが、日を追うごとに失 禁量が減少していくことを確認でき、患者の 励みとなった。

K氏の場合、バルンカテーテル抜去後11日 目に尿失禁が止まった。退院予定の 3 日前で あり、入院中に尿失禁が改善され一安心され ていた。

失禁量および排尿量の推移

（表 I）

\begin{tabular}{|c|c|c|r|}
\hline 月/日 & 失禁量 $(\mathrm{g})$ & 才幺”交回素 & 一回非量 $(\mathrm{ml})$ \\
\hline $8 / 24 \sim 8 / 31$ & $700 \sim 860$ & $7 \sim 10$ & $85 \sim 150$ \\
\hline $9 / 1 \sim 9 / 4$ & $300 \sim 500$ & $5 \sim 7$ & $100 \sim 150$ \\
\hline $9 / 5 \sim 9 / 8$ & $30 \sim 100$ & $1 \sim 3$ & $150 \sim 200$ \\
\hline $9 / 9 \sim 9 / 12$ & 0 & 0 & $150 \sim 200$ \\
\hline
\end{tabular}

VI考察

尿失禁している患者に対し、より快適な日 常生活を過ごせるよう援助していくことは看 護の重要な役割である。

今回、本症例に対しネットパンツを使用した ところ、オムッ固定の問題を解決出来、使い 心地も良いと好評であった。

現在、失禁用具として様々なオムツやオムツ カバーが改良され発売されており、患者の好
みに応じて用具を選択していく必要があるが 患者の経済的負担も考虑し、病院にあるもの を利用し提供していくことも大切ではないか と考える。

一般に失禁は患者に様々な心理反応をひき おこすと言われている。

排泄の失敗は患者に強い心理的ダメージを与 え、自信を失わせ、失禁状態が続けば人間と しての尊厳を唑失することにもなりかねない 前立腺全摘出術後の患者は皆「今、この時期 を碩張れば良くなる。」と信じ、コンチネン スを目標に努力している。しかし前述のよう な精神状態に陥る危険性もはらんでいる。 その中で看膵婦は一喜一憂する患者を励まし 精神的な支えとなることが必要であると考え る。

\section{VIII結論}

前立腺全摘出術後の尿失禁に対する援助を した結果、

(1)前立腺癌患者の場合、疾病そのものへの不 安は勿論あるが、それ以上に術後の尿失禁に 対する不安が大きい。

(2)より快適な日常生活を過ごせるよう陰部の 清潔保持に努めることは看詠の重要な役割で ある。

(3)オムッ固定のパンツは患者の好み、尿失禁 の量、経済的問題を含め患者とともに考え、 選択していく必要がある。 という結論を得た。 VIII参考・引用文献

1.鎌田ケイ子 : 尿失禁ケアマニュアル

日本看護協会出版会

2.看護学雑誌、失禁看護に目を向けよう 医学書院 1989.6 .

3.月刊ナーシング、“失禁”をあきらめな いで 学研 1989 Vol.9 
○石塚文子, 小林君枝, 羽田英子, 唯根理子, 大黒晶乃

椎貝達夫

【はじめに】慢性腎不全治療「取手方式」 は 6 年目を迎え、参加した延べ患者数は 350 名となり、現在約 180名の患者が通院中であ る。食事療法のコンプライアンス良好群の率 は約70\%まで改善された。今後、新たに食事 療法を開始する患者がどうしたら低たんぱく 食が容易に実行できるかを探るため、通院患 者が実行している食事療法についてアンケー 卜調査をしたので報告する。

【対象及び方法】当院に通院中の慢性腎不 全患者を対象とし、食事療法に関するアンケ 一ト調査を実施した。

24時間蓄尿により尿素窒素排泄量からたん ぱく質摂取量を推定し、A群 $(\leqq 0.7 \mathrm{~g} / \mathrm{kg})$ day)と B 群 ( $>0.7 \mathrm{~g} / \mathrm{kg} / \mathrm{day})$ に分けて比較検 討した。患者背景は表 1 に示す。

\section{【結果及び考察】}

1. 栄養指導の回数は A B 群ともさほど変わ らないが、A群では約 $80 \%$ が 1 ～ 2 回の指導 で実行できるようになっている（図1）。

2. 教育入院経験者は $\mathrm{A}$ 群では $36.1 \%$ と $\mathrm{B}$ 群 の約 2.5 倍で、教育入院の効果は大きい（図 2 )。

3. 食事療法を始めたときはAB群とも栄養 計算をしたり、見本献立を参考にしてきちん と実行する人が多かったが、慣れてくると目 分量になる人が多くなってきた（図３）。

4.女性では高齢者の一部を除いて全員が自 分で調理しているが、男性では自分で調理す る人は $\mathrm{A}$ 群で $21.4 \%$ と B 群の約 2 倍となって おり、特に男性では本人が調理に参加してい
(総合病院取手協同病院栄養科)

同

内 科)

る人は好成績であった（図4）。

5.A群では主食からのたんぱく質捸取を少 なくするため、特精米やでんぷん米を使用し ている人は $82 \%$ と多いが、B群では $47.3 \%$ と 少なく、精白米を使用している人が多かった (図5)。

6. 特殊食品を使用しないと食事療法が難し いと感じている人はA群では $70.8 \%$ なのに対 してB群では特殊食品を良く理解されていな いのか $38.5 \%$ と少なかった。また A 群では多 種類の特殊食品を使用している人が多く、バ ラエティーに富んだ食事をしていると思われ る(図6、7)。

7. A B 群とも $70 \%$ 以上の人が外食をしてい るが、回数で比較すると、A群の方が少ない 人が多かった（図 8 ）。現代の社会情勢から 外食を禁止することは困難であるが、できる だけ回数を減らしたり、メニューの選び方に 注意することが重要である。

8. 食事療法を始めたばかりはA B 群とも半 数以上の人がかなり大変だと感じていたが、

慣れてくるとそれほど大変でなくなり、楽に なったという人が増えている（図9）。

【まとめ】食事療法は、最初は大変である が正確にマスターしてしまえば後はかなり楽 になる。確実に実行できるようになれば目分 量でもよいが、時々は点検する意味での食品 の計量計算をさせることが大切である。また 特殊食品なしでは長期に継続させることは困 難であり、これらの食品は低たんぱく食を実 行するうえで不可欠であると思われる。 
表 1 患者背貫

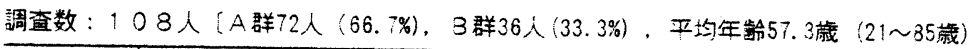

(単位: 人)

\begin{tabular}{|c|c|c|c|c|c|c|c|c|c|c|c|c|c|c|c|c|}
\hline \multirow{2}{*}{\multicolumn{2}{|c|}{ 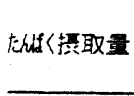 }} & \multicolumn{2}{|c|}{ 性 别 } & \multicolumn{3}{|c|}{ 平 } & \multicolumn{3}{|c|}{ 齢 } & \multicolumn{5}{|c|}{ 酠 } & \multicolumn{2}{|l|}{ 業 } \\
\hline & & 男性 & 女性 & 20 代 & 30 代 & 40 代 & 50 代 & 60 代 & 70 代以上 & 事柊系 & 技誧系 & & 業 & 自営業 & 三婦業 & 年金生活者 \\
\hline A & 群 & 42 & 30 & 1 & 8 & 10 & 23 & 22 & 8 & 17 & 8 & & 2 & 16 & 10 & 18 \\
\hline$B$ & 群 & 24 & 12 & 2 & 3 & 4 & 8 & 12 & $T$ & 8 & 4 & & 3 & 4 & 7 & 9 \\
\hline
\end{tabular}

1 2回 $囚 3 \sim 4$ 回 5回以上

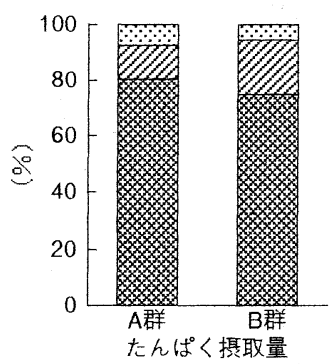

図 1 栄養指導の回数

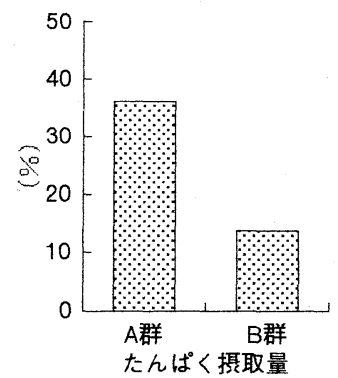

図 2 教育入院経倹者の割合
栄養計算 目分量 典 無回答

䀦見本献立 教育入院

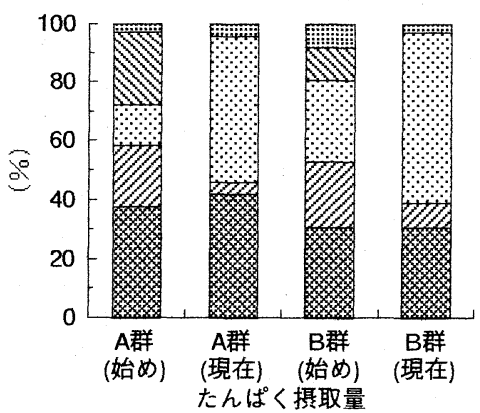

図 3 食事療法の始めの入り方と現在の方法

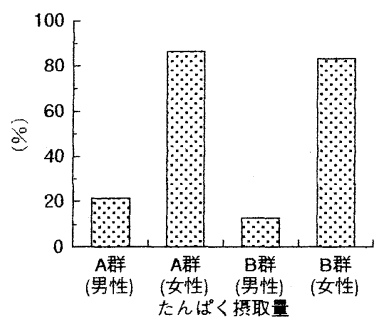

图 4 本人が調理を担当している割合 (A群: 35 人, B群 : 13人)



図 5 ご飯の種類

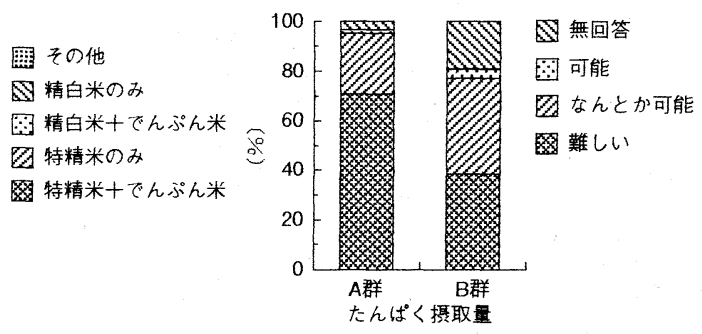

図 6 特殊食品を使用しないで食事癔法が可能か？

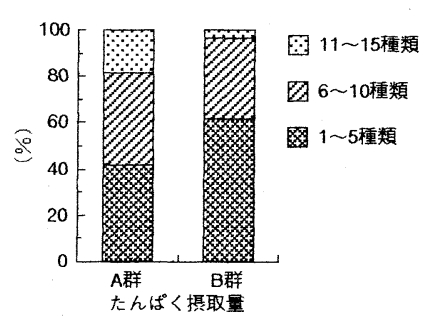

図7使用している特殊食品の種類

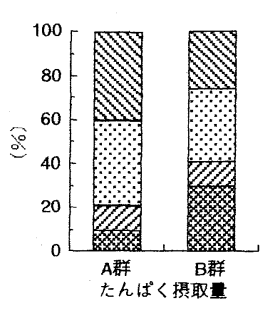

図8 外食の回数 (A群: 52人， B群：27人)

1 回 $/$ 日

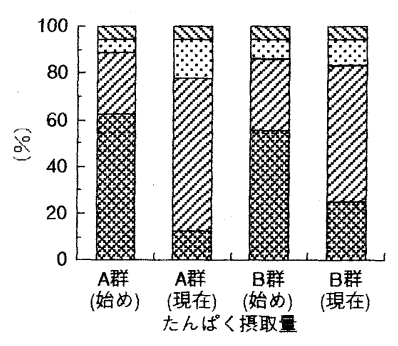

買回答

囦楽である

ஐそれほど大変

かなり大変
证回/月

因 1 2回/遇

図 9 食事癔法の感じ方 
$1 \mathrm{II} 6$

\section{「取手方式」中の腎不全進行完全抑止例}

○椎貝達夫 羽田俊彦 服部光治 岩本 均

(総合病院取手協同病院内科)

\section{【目的】}

1987年11月に開始された保存期慢性腎不全 （CRF）の進行抑制のための治療法「取手 方式」は、 5 年 6 力月の間にのべ 353 名の患 者が参加し、現在通院中は 172名、低たんぱ く食（L P D ）が実行できている率は69\%で ある（表 1 ）。長い経過の中でたんにC R F 進行速度が遅くなっただけではなく、進行が 完全に抑止されている例もみられるようにな った。今回とくに腎機能が大きく低下しなが ら進行が抑止されている例について述べ、今 後の C R F 治療を展望したい。

\section{【方法】}

対象はクレアチニンクリアランス ( C c r r ) $30 \mathrm{~m} 1 / \mathrm{min} / 1.73 \mathrm{~m}^{2}$ 以下のいわゆる “不可逆性 腎不全”10例で、L P D開始前にC R F の進 行性が確認されている。L P D はたんぱく $0.6 \mathrm{~g} / \mathrm{kg} / \mathrm{d}$ を目標とし、24時間蓄尿中の尿素 窒素排泄量、体重からたんぱく摂取量 ( P r I ）を求め、モニタリングとした。 C c r は24時間蓄尿により1力月毎に、G F R は $99^{\mathrm{m}} \mathrm{Tc}$ - D T P A を用いGates 法で 6 力月毎 に測定した。

\section{【成績】}

表 2 に対象例を示した。全例慢性系球体腎 炎（CGN）であり、血清クレアチニン值は $1.9 \sim 4.9 \mathrm{mg} / \mathrm{d} 1$ 、G F Rは $6 \sim 26 \mathrm{ml} / \mathrm{min}$ 、血 圧は $\mathrm{C}$ a 拮抗薬等によりいずれの例でも良く 調節されている。

図 1 に示すように、血清クレアチニン值の 逆数でみると L P D開始後すべての例で著明
な進行抑制がみられた。図 2 に示すように $\mathrm{G}$ F R はすべての例で治療開始時の值かあるい はそれ以上の值を示した。また図 3 に示すよ うに、蓄尿から求めた P r I の症例毎の平均 值は全例 $0.7 \mathrm{~g} / \mathrm{kg} / \mathrm{d}$ 末満であり、また10例中 8 例はP r I の変動係数 ( C V ) が15\%以下 であった。図には示さないが尿中たんぱく排 泄量は $0.5 \mathrm{~g} / \mathrm{d}$ 未満が 4 例、0.5 $1 \mathrm{~g} / \mathrm{d}$ が 5 例と少ない傾向を示した。

\section{【考察】}

今回の成績は L P D がたんに C R F 進行速 度を遅くするだけでなく、進行を完全に抑止 する可能性を示している。患者側からみると L P D は透析までの時間稼ぎなのか、あるい は透析を回避できる治療なのかにより、その 価値ははるかに違う。過去に進行性が確認さ れ、しかもすでに G F Rが30m1/min以下とい う悪条件下でありながら多数の症例が $12 〜 48$ カ月にわたり GF Rが安定していた。これら の例の特徴は尿たんぱく排泄が比較的少ない こと、およびL P D が動摇することなく良く 守られていた点である。このような条件を満 足させるのはそう困難なことではない。今後 他の腎不全悪化原因である感染、過労に対す る対策が進歩すればたとえ高度に腎不全が進 行した状態でL P D を開始してもその時点の G F Rで固定させ、透析を回避できる例が多 数出現すると思われる。

\section{【結論】}

進行性でかつGF R 30ml/min以下のC R F 例で L P D により 12〜48 月間にわたり G F 
Rが低下しない10例を提示した。尿たんぱく 排泄量が少なく、L P Dを安定して実施して いる例が多かった。尿たんぱく排泄の少ない C R F では厳格な L P D で生涯透析療法を回 避できる可能性がある。

\begin{tabular}{|c|c|}
\hline \multicolumn{2}{|c|}{$\begin{array}{c}\text { 取壬式式䒠緗 } \\
(1987-1993)\end{array}$} \\
\hline 参加患者数 & 35 3名 \\
\hline 通院中 & 172 名 \\
\hline $\begin{array}{l}\text { 低たんぱく食 } \\
\text { 実施率 }\end{array}$ & $69 \%$ \\
\hline
\end{tabular}

表 1



図2

\begin{tabular}{|c|c|c|c|c|c|c|c|c|}
\hline & 骨笑愚 & 性 & 年糩 & $\begin{array}{c}\mathrm{Scr} \\
(\mathrm{mg} / \mathrm{dl})\end{array}$ & $\begin{array}{c}\mathrm{Crr} \\
(\mathrm{m} \ell / \mathrm{min})\end{array}$ & $\begin{array}{c}\text { GFR } \\
(\mathrm{ml} / \mathrm{min})\end{array}$ & $\begin{array}{c}\text { 血 } E \\
(\mathrm{mmHg})\end{array}$ & 降压蔡 \\
\hline 1. & CGN & 男 & 73 & 3.7 & 21 & 8 & $134 / 82$ & C a 拮抗薬 \\
\hline 2. & CGN & " & 63 & 4.9 & 12 & 6 & $134 / 80$ & C a 拮抗薬 \\
\hline 3. & CGN & 女 & 72 & 1.9 & 21 & 26 & $134 / 80$ & C a 拮抗薬 \\
\hline 4. & CGN & " & 67 & 3.3 & 19 & 14 & $134 / 86$ & $\beta$ 遮断察 \\
\hline 5. & CGN & " & 64 & 2.0 & 21 & 21 & $134 / 82$ & A C E 阻害薬 \\
\hline 6. & CGN & " & 60 & 3.6 & 17 & 15 & $134 / 86$ & C a 拮抗薬 \\
\hline 7. & CGN & " & 50 & 2.4 & 18 & 16 & $146 / 86$ & $\beta$ 遮断薬 \\
\hline 8. & CGN & " & 50 & 2.2 & 17 & 11 & $134 / 86$ & $A C E$ 阻害薬 \\
\hline 9. & CGN & " & 43 & 4.0 & 14 & 18 & $140 / 86$ & C a 拮抗薬 \\
\hline 10. & CGN & " & 42 & 4.7 & 10 & 13 & $142 / 88$ & C a 拮抗蔡 \\
\hline
\end{tabular}

表 2

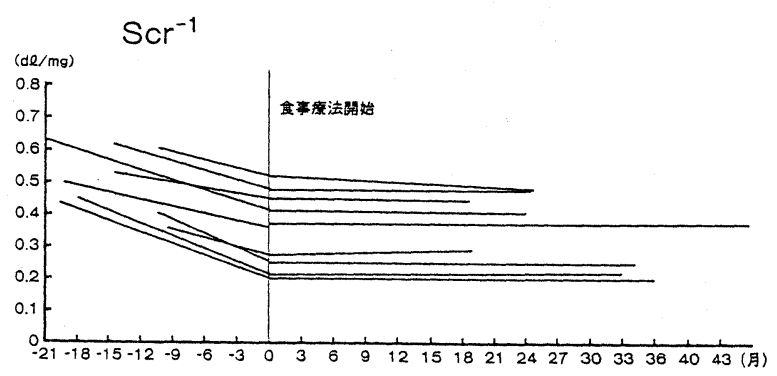

図 1

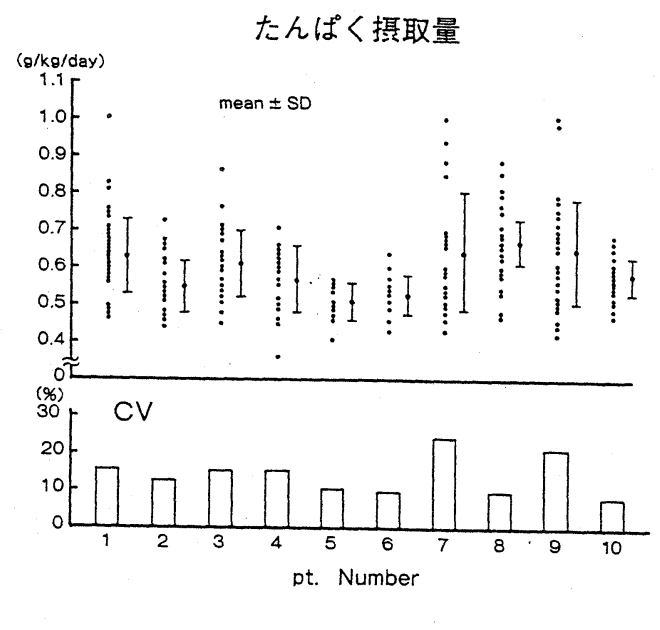

図3 
$1 \mathrm{II} 7$

慢性維持透析導入例の検討

一過去 5 年間つ糖尿病性腎症例を中心に一

相模原協同病院 腎臓内科透析室

O関正人

山崎洋子
小島弘之

田部フク子
栃原敏彦

石井昭 郎
はじめに

1991 年 12 月現在のかが国の慢性透析療法 の現況（日本透析療法学会）をみると, 約 11 万人が透析を受けて招り，年々新規導入患者も 增加して, 平均年齢の上昇及び糖尿病性督症を 原疾患とするものの增加が目だっている。9 1 年導入患者の全国平均は 58.2 歳であり, 糖尿 病性䐌症を原疾患としているものは $27.8 \%$ と なっている。

当院に括いても昨年度導入例のなかで糖尿病性 腎症が多数をしめたため, 今回, 過去 5 年間の 慢性維持透析導入例を調べ, 特飞糖尿病性腎症 例飞関して臨床的検討を加光た。

『対象及び方法』

1988 年から 1992 年の 5 年間に当院にて 慢性維持透析を導入した患者を対象とした, 特 続性尿蛋白を認为, 眼底変化を伴亏糖尿病性腎 症例飞関して, 導入後半年以内に死亡した例

(早期死亡例) と 2 年以上維持透析している症 例（ 2 年以上維持透析例）を比較検討してみた。 『結果『

1. 慢性維持透析導入例

当院では 5 年前より新透析室飞移転して，17 台の透析べットで血液透析を行ってきた。

外来患者数の増加とともに表 1 のよら 維持透 析導入例も增加し, 合計 43 例となった。 導入時の年齢飞大きな差はなく 36 歳から 83 歳迄の症例であり, 若干男性が多い傾向飞あっ た。原疾患別飞みると, 糖尿病性腎症 16 例, 慢性腎炎 15 例, 腎硬化症 7 例, 多発性囊胞腎
3 例, 慢性腎孟炎 1 例, 痛風路 1 例である。 糖尿病性腎症は表 2 の上らに年々增加して92 年飞急增している。9 2 年の慢性維持透析導入 例の内訳性, 糖尿病性腎症 9 例, 慢性腎炎 1 例, 腎硬化症 2 例, 痛風腎 1 例である。表には示し ていないが, 93 年 1 月から 6 月迄の 8 例の新 規導入例飞扮いても糖尿病性腎症は $50 \%$ と多 かった。

\section{2. 糖尿病性腎症例の検討} 導入後, 半年以内に死亡した症例は 4 例で, 平 均透析期間は 3.68 力月, 一方, 2 年以上の透 析例は 5 例であり 45.91 カ月の平均透析期間 であった。表 3 のよらと早期死亡例では，

Total Protein, albuminが有意飞低かった。 統計学的には有意ではないものの, 早期死亡例 では心胸比, コレステロール值が高い傾向にあ りネフローゼ状態の強いことが示唆された。 腎機能，血糖のコントロールには差がなかった。 『考案】

当院に括ける過去 5 年間の慢性維持透析導入例 をみると，導入時年粭には大きな変化は見られ ないものの, 糖尿病性腎症が急增して和り, 院 内のみならず, 地域としての糖尿病の管理, 指 導の更なる充実が必要と思われた。 
表1

導入患者数

導入時年齢

\begin{tabular}{lrl}
88. & 5 & $57.80 \pm 9.98$ \\
89. & 6 & $69.50 \pm 11.88$ \\
90. & 10 & $59.60 \pm 14.67$ \\
91. & 9 & $59.77 \pm 12.13$ \\
92. & 13 & $57.85 \pm 12.71$ \\
\hline
\end{tabular}

表2

NUMBER OF

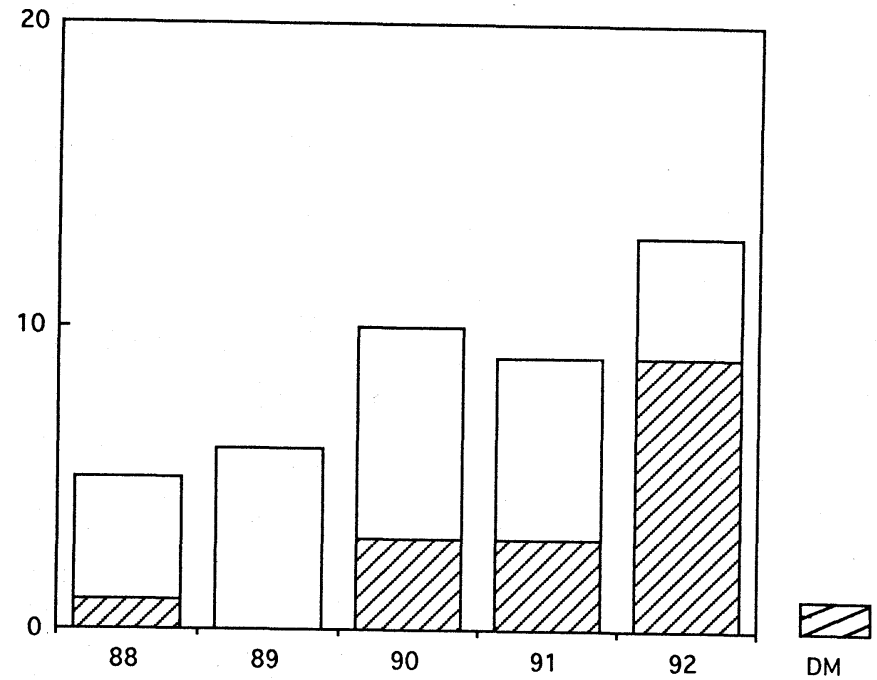

表3

\begin{tabular}{|c|c|c|c|}
\hline & $\begin{array}{c}\text { 早. 期 死 亡 例 } \\
n=4\end{array}$ & $\begin{array}{c}2 \text { 年 以上透析 例 } \\
\mathrm{n}=5\end{array}$ & \\
\hline 導 入 時 年 齢 & $59.25 \pm 14.43$ & $61.2 \pm 3.77$ & N.S \\
\hline 透 析 期 間 （月） & $3.68 \pm 2.33$ & $45.91 \pm 26.41$ & \\
\hline 心 胸 比 & $59.75 \pm 7.27$ & $53.8 \pm 8.61$ & $N \cdot S$ \\
\hline T.Protein & $5.13 \pm 0.28$ & $6.08 \pm 0.69$ & $\mathrm{p}<0.05$ \\
\hline a $1 \mathrm{bum} \mathrm{in}$ & $2.43 \pm 0.25$ & $3.28 \pm 0.66$ & $\mathrm{p}<0.05$ \\
\hline BUN & $79.23 \pm 18.37$ & $68.92 \pm 18.23$ & $N \cdot S$ \\
\hline creatinine & $7.5 \pm 7.06$ & $7.88 \pm 2.41$ & N.S \\
\hline $\mathrm{UA}$ & $6.63 \pm 1.92$ & $7.26 \pm 2.55$ & $\mathrm{~N} \cdot \mathrm{S}$ \\
\hline $\mathrm{TC}$ & $233.75 \pm 52.86$ & $144.75 \pm 56.81$ & N. S \\
\hline $\mathrm{H} \mathrm{D} \mathrm{L}-\mathrm{C}$ & $43.5 \pm 16.36$ & $38.67 \pm 14.74$ & $N \cdot S$ \\
\hline T G & $253 \pm 124.3$ & $122.5 \pm 61.07$ & $N \cdot S$ \\
\hline F B S & $191 \pm 94.81$ & $159 \pm 36.44$ & $N \cdot S$ \\
\hline $\mathrm{HbA} 1 \mathrm{c}$ & $7.2 \pm 1.39$ & $7.06 \pm 1.16$ & $N \cdot S$ \\
\hline $\mathrm{H} \mathrm{t}$ & $25.65 \pm 8.85$ & $26.56 \pm 6.70$ & $N \cdot S$ \\
\hline $\mathrm{Hb}$ & $8.65 \pm 2.86$ & $8.94 \pm 2.13$ & $N \cdot S$ \\
\hline Ins u $1 \mathrm{in}$ & $1 / 4$ & $3 / 5$ & \\
\hline
\end{tabular}




\section{I18 持続的血液沪過透析が有用であった多臓器不全の一例}

白河厚生総合病院透析室口斎藤正志丸山幸男 泌尿器科伊藤晋 新井元凱

\section{1.はじめに}

急性腎不全（ARF）の治療には、通常血 液透析（H D ）や腹膜灌流（P D ）が行われ ている。しかし、全身状態の不安定な症例に 対しては、急激な体液の質的・量的な变化を 伴うため、循環動態に与える影響が大きく中 断を余儀なくされることむ少なくない。最近、 多臓器不全（MOF）の一分症としてのAR $F$ に対する緩徐な血液净化法として持続的血 液浄化法（C B P） が普及してきている。

今回我々は、経尿道的前立腺切除術後に心 不全・肺水腫・AR F を合併した 80 歳男性に 対して C B P を施行し、急性期を脱し得た。 そこで、C B P の有効性扔よび問題点につい て若干の考察を加え報告する。

\section{2. 症例}

症例：80歳、男性。

主訴：排尿困難。

既往歴：大動脈弁閉鎖不全を指摘されていた が、特に治療は受けていない。

家族歴：特記すべきととなし。

現病歴：約 10 年前より排尿困難を自覚し他医 にて保存的治療を受けてきたが、排尿障害が 増強したため、前立腺肥大症の診断で手術が 予定された。入院時の心電図で完全左脚ブロ ックを認め、心エコーにて中等度の大動脈弁 閉鎖不全を認めるものの、心拡大なく心機能 あ正常で脊椎麻酔下に経尿道的前立腺切除術 を行った。手術時間は48分、出血あ少なく術 中に血圧変動や不整脈などあ認めず手術は終 了した。手術翌日より発熱、咳、咽頭痛が出

麻酔科岡崎美智也管桂一
現し、次第に増強した。術後 5 病日の胸部レ ントゲン写真で肺水腫を認め、呼吸困難、低 酸素血症がみられたため、気管内挿管、人工 呼吸器にて管理した。乙の際、カテコラミン にあ反応しない低血圧が約 6 時間持続し、乙 の間の尿量は $95 \mathrm{ml}$ であった。その後は打打よ 之 1 時間あたり $50 \mathrm{ml}$ の尿量を確保できたが、 6 病日より B U N 、 C r の上昇を認めた。6 病日の心電図では $V_{3} \sim 6$ で陰性 $\mathrm{T}$ 波を認め、 心エコーでは全体に hypokinetic となってお り C P K、C P K - M B の上昇とああわせて 急性心筋梗塞を併発したと考えた。術後 10 病 日まで利尿剤等で経過を観察したが B U N 、 C r の上昇が続くため、多臓器不全を伴った 急性腎不全亡の診断で持続的血液沪過透析法 （CHDF）を開始した。

方法：ブラッドアクセスとして A r g y 1 社 製ブラッドアクセス U K ダブルルーメンカテ ーテル（コアクシャル型）を大腿静脈に挿入、 留置し、血流量は $100 \sim 150 \mathrm{ml} / \min$ とした。 プライミングボリューム54 ml 小坚用回路、 フィルター（クラレ・P S フィルターC F 0. 4 ）を用いた。また、フィルターは2 4 時間を 目安に交換した。血液透析の監視装置を用い、 灌流液用にニプロ社製マルチポンプを用いて 注排液を同時に行なった。沪過液（除水）は 排液ラインのマルチポンプの前より輸液ポン プを用いて除去した。沪過量（除水量）は血 圧等の状態をみながら $20 〜 50 \mathrm{ml} / \mathrm{hr}$ で除去し た。灌流液は、滅菌であることが第一条件で あるため沪過型人工腎臟用補液サブラットA 
液（扶桑）を使用し、流量 $500 \sim 1000 \mathrm{ml} /$ $\mathrm{hr}$ とした。重篤な出血性病変は認められなか ったため抗凝固剤としてはへパリンを用い、 $400 \sim 600 \mathrm{IU} / \mathrm{hr}$ で持続注入した。なお、 活性化凝固時間（A C T ）はへモクロンを用 い経時的にチェックした。

経過：約64時間の C H D F により B U N 63. $9 \mathrm{mg} / \mathrm{dl}$ から $30.9 \mathrm{mg} / \mathrm{dl}$ へ、C r $6.46 \mathrm{mg} / \mathrm{dl}$ から $2.64 \mathrm{mg} / \mathrm{dl}$ へと低下した。また、20〜50 $\mathrm{ml} / \mathrm{hr}$ の沪過を行なったにあかかわらず、数 時間後には血圧上昇を認めた。また心拍数む 変わらず、不整脈の新たな出現も認められな かった。回路内凝固による交換は 1 回のみで ヘパリン注入による出血性合併症もなく、A C T は約 $160 〜 200$ 秒の範囲であった。 その後は間歇的にH Dを行うのみで、B $\mathrm{N} \cdot \mathrm{C} r$ をコントロールできた。

しかし、本症例は治療の長期化が予想され、 当院の管理体制の面からむやむなく他病院集 中治療室（ＩＣＵ）にその後の管理を依頼す るとととなった。転院後、肺水腫が一時増悪 し、I C UでC H D F を約 3 日間、さらに H Dを 1 回施行した。その後の経過は良好で、 人工呼吸療法 - 血液浄化法と屯離脱し、55病 日当院泌尿器科へ転院となり、現在は外来通 院中である。

\section{3. 考察}

C B P の中でも、最も早期に普及し、その 有用性が認められたのは、1977 年、Kramer らによる持続的動静脈血液沪過法 ( C A V H ) である。現在は、その原理およびシステムに より、幾つかに分類され、個々の症例に適し た治療法が選択されている。C B P の最大の 利点は、安定した循環動態のもとに治療を継 続できることである。また緩徐にかつ、持続 的に長時間施行することは生体の糸球体によ
り類似した治療法であるため、生体への負荷 がマイルドであり、補液やカロリー投与が計 画的に行なえる利点を有す。特に、C H D F は大量補液一大量沪過をせずと屯溶質除去能 が良好であり、生体によってより負担の少な い治療法と言える。

本症例は 80 歳と高齢であり、全身状態から みても治療に耐え得るか否か懸念されていた が、実際には血圧低下や不整脈等の出現むな く、施行中全般に渡り循環動態は安定してい た。また少ない血流量、灌流液流量で十分な 治療効果が得られ、危機的な急性期を脱し、 他院へ搬送できる状態にまで回復することが できた。本来なら当院にて C B P を継続する ことが最善ではあったが、I C Uが開設され ていない当院の現状では非常に困難なものが あった。そこで、他病院 I C U一転院させ、 経過管理を依頼せざるを得なかった。

以上のととから、MOFに代表される全身 状態の不安定な症例に対しての血液浄化法と して、C H D F は非常に有用であり、今後、 そうした症例に対して積極的に取り入れるべ き治療法であると考える。同時に高齢化社会 を迎え、C B P の対象となる症例が増加する ことが予想されるため、C B P が行なえるよ うな管理体制の整備も必要であると考える。 


\section{透析導入患者の透析前治療歴の検討}

一検診活動と保存期治療の推進によりどこまで導入患者数は減少可能か -

○西尾康英, 佐久間資子, 木本成昭, 杉本圭市, 磯村孝二 清水善次

\section{（長野県厚生連北信総合病院 内科）}

【背景】透析患者は近年増加の一途を辿り， 重大な社会問題ともなった医療費の増大抑 制の視点からも,新規導入患者数の抑制策は 必須の課題である。腎疾患の早期発見は検 診活動の普及により達成されつつある。一 方,㚈パ 制限食を中心とする保存期の食事 療法により，腎不全の進行抑制が可能である ことも近年の腎不全医療の成果として着目 されている。

しかし，現実にはまだその恩恵をこうむら ずに透析導入に至っている患者が数多い。 当院においても近年,同治療法を積極的に取 り入れているが,透析患者の増加は依然続い ている。

【目的】当院における近年の透析導入患者 の透析に至るまでの治療歷,保存期腎不全の 食事療法の実施状況を検討することにより， 今後保存期腎不全治療の完壁な実施により 透析導入患者数をどこまで抑制可能かを考 察する。

【対象と方法】当院において過去3年間に 透析導入となった症例 42 例が対象（急性腎 不全の導入例，他施設からの転入例は除く）。 慢性腎不全の原因疾患，腎不全の診断年月， 当院への初診年月を病歴から調查した。食 事療法の適応状況について,実施の有無とそ の内容,継続期間,実行状況を病歴の記載か ら判定した。食事療法の適用については 40g以下の舛パ ク制限例のみを腎不全の食事 療法の実行例とし, 塩分制限のみ，あるいは $50 \mathrm{~g}$ 越える外パ 制限は食事療法非実行例 とした。食事の遵守状況については，入院治 療例,あるいは外来で蓄尿による外パク摄取
量が評価されている例のみを完全遵守例と みなした。

【結果】当院の透析導入患者の推移を図1 および表1に示す。ここ数年新規導入数の 増加があるが93年度は半年間で5例と減少 の兆しがある。表2に原疾患別にみた透析 前の治療歴を示す。腎不全の診断から透析 導入までの期間は原疾患により差がみられ るものの,血清 $\mathrm{Cr} 2 \mathrm{mg} / \mathrm{d} 1$ 以下の腎障害の初期 から当院で一環して治療継続している例は 18例と半数以下で,末期腎不全に陥り初めて 紹介される症例が目だった。

表3に保存期の食事療法の適応歷を示す。 病歴あるいは他院からの紹介状に食事指導 内容が明確に指示されているものを実施例 としたが,それらは20例と全体の半数以下で ありそのらち3例は実施後一か月以内に導 入となった末期の適応だった。 $\mathrm{Cr} 4 \mathrm{mg} / \mathrm{dl}$ 以 下の初期の腎不全から食事療法が開始され ていた例は4例のみであった。指導内容別 にみると,外パ ク40gの軽度の制限例が多く， さらに外来治療において摄取状況が把握さ れている例は4例のみであった。

【考察】過去3年間の透析導入患者のらち, 腎不全保存期の食事療法が行われていた例 は半数以下であり,適応例も末期の腎不全で の実施例が多かった。完全遵守にもかかわ らす導入となった例は,入院治療例を除くと 4例のみであり,いずれも血清 $\mathrm{Cr}$ が $5 \mathrm{mg} / \mathrm{dl}$ を 越えてからの適応であった。多パ少制限食 の腎不全進行抑制への有奻性が提唱されて から久しいが、現実には漫然と塩分制限のみ が指導されていたり，指導内容も多パク40gの 
軽度の制限が口頭で指導されたのみで，食事 の遵守状況が把握されていない場合が多い。 $\mathrm{Cr} 4 \mathrm{mg} / \mathrm{d}$ 以下の早期から完全に食事が守ら れている例の導入はまだ見受けられないこ とから，多パク制限食が期を逃さずに適応さ れていれば、これら導入症例の半数以上は 導入時期を延長あるいは回避できたと想定 される。

【結語】腎疾患の早期発見は検診活動の推 進により達成可能であるが，腎不全進行の抑 制のためには，早期からの食事療法の正し い適応，指導された食事が完全に守られるた めの医療環境（資材の提供,指導体制,患者 の理解と協力）の整備,のすべての条件が必 要であり,現状においてはいずれも不十分で ある。今後それらの各用件の実行により透 析導入患者数は大幅に減少可能と期待され る。

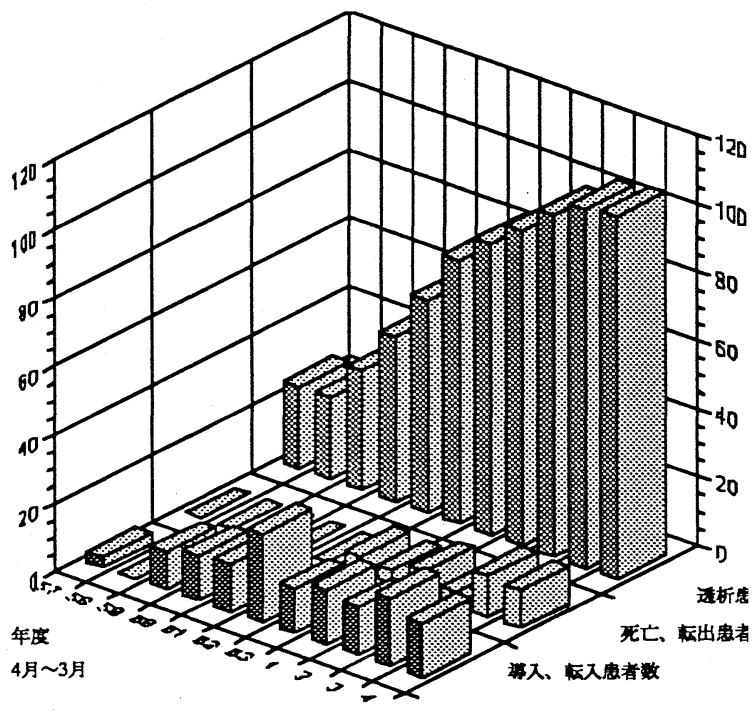

目 1 当院の透析導入患者の推移

表 2 透析導入までの治療歷（平均土 $\mathrm{SD}$ (最小〜最大)を示す)

\begin{tabular}{|l|l|l|l|l|}
\hline $\begin{array}{l}\text { 原因 } \\
\text { 疾患 }\end{array}$ & $\begin{array}{l}\mathrm{CRF} \text { 診断時 } \\
\text { 血清 } \mathrm{Cr}(\mathrm{mg} / \mathrm{dl})\end{array}$ & $\begin{array}{l}\mathrm{CRF} \text { 診断から } \\
\text { 導入までの月数 }\end{array}$ & $\begin{array}{l}\text { 当院初診時: } \\
\text { 血清 } \mathrm{Cr}\end{array}$ & $\begin{array}{l}\text { 初診から } \\
\text { 導入まで月数 }\end{array}$ \\
\hline $\mathrm{CGN}$ & $4.3 \pm 2.2$ & $42.0 \pm 43.0$ & $5.3 \pm 4.0$ & $55.2 \pm 71.4$ \\
& $(2.0 \sim 8.4)$ & $(0 \sim 173)$ & $(0.9 \sim 16.8$ & $(0 \sim 210)$ \\
\hdashline $\mathrm{DMN}$ & $3.7 \pm 1.8$ & $12.5 \pm 11.0$ & $3.3 \pm 2.4$ & $55.1 \pm 65.5$ \\
& $(1.8 \sim 6.9)$ & $(0 \sim 31)$ & $(0.7 \sim 6.4)$ & $(0 \sim 174)$ \\
\hdashline $\mathrm{PCK}$ & $2.7 \pm 0.9$ & $34.3 \pm 20.1$ & $3.6 \pm 3.0$ & $79.8 \pm 84.0$ \\
& $(2.0 \sim 4.3)$ & $(6 \sim 59)$ & $(0.7 \sim 9.1)$ & $(1 \sim 238)$ \\
\hline 全体 & $3.8 \pm 2.0$ & $33.1 \pm 36.8$ & $4.4 \pm 3.6$ & $60.3 \pm 70.9$ \\
\hline
\end{tabular}

表 1 過去3年間の導入患者の臨床像

表 3 透析導入前の食事療法実施状況

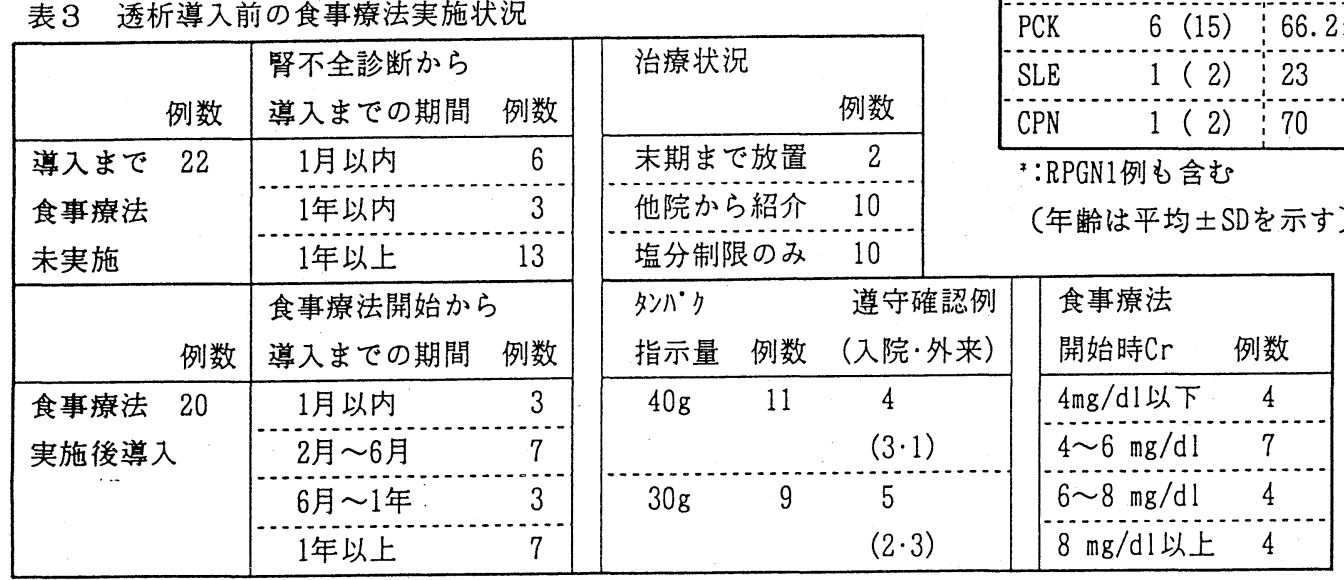

\begin{tabular}{|l|c:c|}
\hline 年 & 例数 & 年齢 \\
\hline 90 年 & 8 & $63.6 \pm 6.3$ \\
\hline 91 年 & 11 & $60.8 \pm 12.3$ \\
\hdashline 92 年 & 18 & $62.0 \pm 15.5$ \\
\hdashline 93 年 & 5 & $60.0 \pm 11.6$ \\
\hline 合計 & 42 & $61.8 \pm 12.9$ \\
\hline "6月まで
\end{tabular}

\begin{tabular}{|lc:l|}
\hline 原疾患 & 例数 (\%) & 年齡 \\
\hline CGN & $22(54)$ & $62.1 \pm 12.8$ \\
\hline DMN & $12(29)$ & $61.4 \pm 11.5$ \\
\hline PCK & $6(15)$ & $66.2 \pm 4.7$ \\
\hline SLE & $1(2)$ & 23 \\
\hline CPN & $1(2)$ & 70 \\
\hline
\end{tabular}

${ }^{*}$ :RPGN1例も含む

(年齢は平均 $\pm S D$ を示す) 
塩分捸取と体重增加との関連について

一塩分制限食の指尊を試みて一

○広瀬由美子、中岡まみ、藤井なほみ、

稲見紀恵、田中扶規子、飯村幸江

米島京子（猿島協同病院 腎センター）

[はじめに]

当院腎センターは、本年で設立 5 年目を迎 之る。本年 3 月末日現在、38名の維持透析患 者がいるが、その平均体重增加率は $6.0 \%$ と 許容範囲をこえているのが現状である。農村 部である猿島地区における平均塩分摄取量が 1 日 $13.6 \mathrm{~g}$ と全国平均と比較し高值であるこ とにより、本院における体重增加率高値の原 因として、過度の塩分摄取が口渴感を助長し、 水分摄取の過剩を招くのではないかと考えた。 そこで、外来患者33名の塩分摄取量を調查し た所、体重增加率との関連性が認められた。

この結果をもとに栄養課と協力し、塩分制限 食の指導をおこなった所、体重增加率が減少 した症例を経験したので、ここに若干の考察 を加えて報告する。

[研究方法及び結果]

(1)期間：平成 5 年 1 月 31 日 平成 5 年 4 月 30 日

(2)対象: 平成 5 年 1 月31日現在当院腎セン 夕ーに通院中の透析患者33名(男性23名、 女性10名)

(3)透析患者の体重增加率：表1のように平 均透析年数と体重增加率との間には明ら かな相関は認められなかった。

(4)調查報告 :

a、アンケート調查（内容および方法）

塩分と水分の制限に対する患者の意識を把握 する目的でアンケートに無記名で記入しても らった結果（アンケート回答者は33名中24名 であった）減塩を心がけようとする人は96\%
いたが、実際は家庭での食事の味付けを薄い と感じる人 $50 \%$ 、味噌汁や漬物を食べている 人は $72 \%$ で体重增加率別にみると 5 群では 80 \%、6群では $100 \%$ もることが判明した。

b、味覚調查 (内容および方法)

濃度の逴う 3 種類の味噌汁（具なしを $1.2 \%$ 、 $1.0 \% 、 0.8 \%$ ） $10 \mathrm{ml}$ 準備し、透析開始前に 試食してもらい感想を聞いた。

結果（施行者は33名中28名であった）

$0.8 \%$ をょうど良いと感じた人 4 名、 $1.0 \%$ を薄いと感じ $0.8 \%$ を濃いと感じた人 4 名、3 つ共ちょうどよいと感じた人が 1 名いた。1. 2\%をちょうど良いと感した 5 名は体重增加率 の高い6群にふくまれていた。

\section{(5)食事指導}

対象: 調查結果から減塩に対する意識が低く、 体重增加率の高い6 群の3症例について指導 を行った。

症例 A、58才女性、透析歴 1 年 8 月 症例 B、43才女性、透析歴 1 年 7 月 症例C、52才男性、透析歴 2 年10个月 指導方法：1、患者の食事内容をより正碓に 把握するため、食事調查表に3日間の食事内 容を患者自身に記入してもらつた。（表2） 2、当院栄養課の協力により、食事調查表の 分析をおこなった。この結果より、以下のポ イントを取り上げ再指導を行った。

a、指示カロリー内で十分な食事を摄ること により满腹感を得、間食を控える。

b、漬物は市販のものではなく、自家製の浅 漬けで一日 3 切れまでとする。 
c、味噌汁は原則として掑らない。摄る場合 は、一日一回、具だけとする。

3、減塩食指導用モデルを用い、各食品の塩 分含有量を把握できるようにした。

結果: 食事調查の結果は、3症例ともエネル ギー、蛋白、塩分とも低いが指導前では自己 申告のため記載もれが多くおせんべい、漬物、 味噌汁等を摄っていることが確認され実際は 塩分䀧取量が多かった。指導後では食事のバ ランスが良くなり塩分に対する自覚が出てき て漬物、味噌汁を控えるようになってきた。 指導を開始し 3ケ月の経過を見ると、体重增 加率、C T R ともに著明な改善がみられた。

（表3）また体重增加率が以前より少ないた め毎回透析後半に見られた血圧低下がなくな た。

\section{[考察]}

安定した維持透析患者を行う上で、患者の 体重コントロールは大きな問題点である。
過度の体重增加は、心、血管系への負担も大 きく、透析中の血圧変動も著明となる。

今回のアンケート調查により、体重增加率の 高い患者ほど、塩分摄取量の多い傾向がある ことが明らかになった。このことにより、患 者の体重コントロールのためには、水分の摄 取制限のみでなく、塩分の制限も徹底されな ければ効果が上がらないと考えられた。さら に、味覚調查、食事調查表より味覚味対する 認識が低く、自己流の食事内容と成っている ものが多いことが明らかになった。特に、長 期透析患者において、この傾向が強く見られ た。これらの患者に対し、食事調查表、減塩 食指導モデルを活用することにより、各自の 塩分に対する認識を高める事が出来たと考之 る。今後、合併症を予防し長期安定した透析 を維持するためには、導入期のみでなく安定 期に食事指導を行い患者が自己管理出来るよ うサポートして行きたいと考える。

(表 1) - 透析患者の体重增加率 -

\begin{tabular}{|c|c|c|c|c|c|c|}
\hline 群 & 1 & 2 & 3 & 4 & 5 & 6 \\
\hline $\begin{array}{c}\text { 体重增加率 } \\
(\%)\end{array}$ & $0 \sim 1.9$ & $2 \sim 2.9$ & $3 \sim 3.9$ & $4 \sim 4.9$ & $5 \sim 5.9$ & $6 \sim$ \\
\hline 人 数 & 4 & 0 & 5 & 3 & 15 & 6 \\
\hline $\begin{array}{l}\text { 平均透析年数 } \\
\text { (年) }\end{array}$ & 2 & & 4. 6 & 2 & 3.6 & 4. \\
\hline
\end{tabular}

（表 2）－食事調查表 -

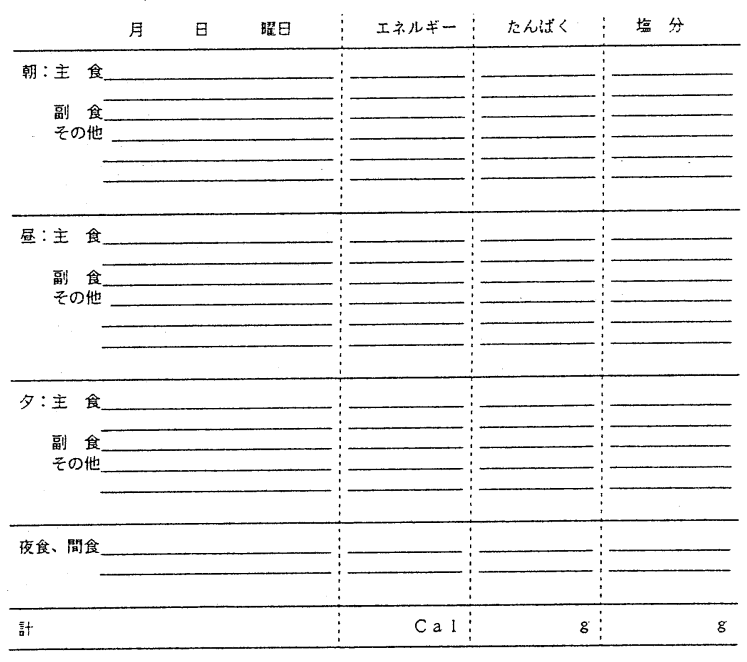

\begin{tabular}{|c|c|c|c|c|}
\multicolumn{4}{c}{ (表 3) } & - 体 重 增 加率 \% - \\
\cline { 2 - 6 } \multicolumn{1}{c|}{} & 1月 & 2月 & 3月 & 4 月 \\
\hline $\mathrm{A}$ & 9.71 & 11.7 & 7.6 & 4.9 \\
\hline $\mathrm{B}$ & 12.6 & 13.8 & 12.7 & 11.0 \\
\hline $\mathrm{C}$ & 6.5 & 6.2 & 5.6 & 5.6 \\
\hline
\end{tabular}

\begin{tabular}{|c|c|c|c|c|}
\multicolumn{4}{c|}{$C \quad T R(\%)$} \\
\cline { 2 - 5 } \multicolumn{1}{c|}{} & 1月 & 2月 & 3月 & 4 月 \\
\hline A & 56.9 & 65.8 & 52.3 & 47.3 \\
\hline B & 㵋定不能 & 測定不能 & 64.1 & 49.1 \\
\hline C & 50.0 & 48.1 & 49.3 & 49.1 \\
\hline
\end{tabular}




\section{$1 \mathrm{I} 21$ 乳幼児の腎エコースクリーニング}

伊勢原協同病院

小児科 0 御宿百合子、滝山宣明、木村和弘、関谷忠助 泌尿器科 柴山太郎、白水幹

腎尿路系はその発生が複雑なため、先天性疾 今後、全国的規模で普及することを期待する。 患が高頻度に認められている。また、小児腎 不全の原疾患として、腎尿路疾患が占める割 合は 30〜 50\%であり、これらの疾患を早期に 発見し、手術などの適切な医療管理を行うこ とが重要である。これらの疾患の主な症状と して、尿路感染症による発熱、腹部腫瘤、腹 痛、肉眼的血尿などがあげられる。これらの 症状を呈した患児に対しては、画像診断法に よる腎尿路系の検索が重要である。また、学 校検索、3歳児検尿などの検尿以上で発見され る症例もあり、検尿異常者に対しても、腎工 コ一検查などによる腎尿路系の検索が必要で ある。しかし、無症候性蛋白尿・血尿で発見 される症例では、すでに腎機能が低下してい る場合が多く、その時点で手術などの治療を 行っても、腎機能障害が持続あるいは進行す る場合もあり、早期発見を目的とした場合、集 団検尿には限界があるのが実情である。そこ で、乳幼児に対する腎エコー検査によるスク リーニングがいくつかの機関施設で試みられ 始めた。

秦野・伊勢原地区保健所でも、3か月検診お よび3歳児検診で腎エコー検査を実施してい る。伊勢原協同病院は2次精査機関の一つとし て、積極的にこの事業に参加している。今回、 当地区の腎エコースクリーニングの結果を報 告し、当院で䛦断された症例については、当 日スライドで紹介する。

腎エコースクリーニングは、先天性腎尿路疾 患の早期発見において、非常に有用であり、

秦野・伊勢原地区保健所の腎エコースクリーニング結果

\begin{tabular}{|l|c|c|}
\hline & 3か月児 & \multicolumn{1}{|c|}{ 3歳児 } \\
\hline エコー実施数 & 5,930 & 6,567 \\
\hline エコー有所見者 & $230(3.9)$ & $100(1.5)$ \\
\hline 2次精査有所見者 & $185(3.1)$ & $65(1.0)$ \\
\hline 要手術例 & $11(0.2)$ & $2(0.03)$ \\
\hline
\end{tabular}

例 (\%)

精密検査所見あり者の内訳（重複あり）

\begin{tabular}{|l|c|c|}
\hline & 3 か月 & 3 歳 \\
\hline 水腎症(腎孟拡張含む) & 145 & 48 \\
\hline 膀胱尿管逆流 & 17 & 1 \\
\hline 水尿管 & 7 & 1 \\
\hline 腎無形成 & 6 & 3 \\
\hline 腎囊胞 & 3 & 5 \\
\hline 低形成腎 & 2 & 3 \\
\hline 尿管瘤 & 4 & 1 \\
\hline 腎不全 & 1 & 0 \\
\hline 巨大腎杯症 & 1 & 0 \\
\hline 骨盤腎 & 1 & 0 \\
\hline L型腎 & 0 & 1 \\
\hline 多霊腎 & 1 & 1 \\
\hline 腎回転異常 & 0 & 1 \\
\hline 卵巣のう腫 & 2 & 0 \\
\hline 尿管異所開口 & 2 & 0 \\
\hline
\end{tabular}


手術症例

\begin{tabular}{|l|c|c|}
\hline & 3か月 & 3 歳 \\
\hline 水腎症(腎孟尿管移行部狭窄) & 4 & 0 \\
水尿管症(搰腅尿管移行部狭窄) & 1 & 1 \\
単純性尿管瘤 & 3 & 0 \\
膀胱尿管逆流 & 2 & 0 \\
完全重複堅孟尿管、尿管瘤 & 0 & 1 \\
完全重複腎孟尿管、膀胱尿管逆流 & 1 & 0 \\
\hline \multicolumn{1}{|c|}{ 計 } & 11 & 2 \\
\hline
\end{tabular}




\section{2 持続膀胱洗浄中の患者の移動を安全安楽にする工夫} い、平均 $3 \sim 4$ 日間であるが、特に歩行開始 後より患者は様々な苦痛を生じる。

今回、持続膀洗中の患者が安全に安楽に移動 日 できるような援助を目的として、実態をアン ケート調査により知り援助方法を検討し、呆 架、洗浄液の固定バンド、尿バッグ掛け等の 工夫を行った。その後再びアンケート調査を 行った結果、患者からあ好評を得ることがで きたのでその成果を報告する。

\section{2. 研究方法}

平成 2 年 9 月から平成 5 年 3 月までの間に 手術後に持続膀洗を行っていた患者50名ずつ を対象に、第 1 回のアンケート調査の結果か ら問題点と解決策を検討実施し、その後第 2 回のアンケート調査を行い評価した。

\section{3. 結 果}

(1)第 1 回のアンケート調查から得られた持続 膀洗中の患者の現状と問題点

(1)洗浄液を点滴台にかけるだけであったこと と、点滴台が 3 本足のものしか使用していな かった為、バランスがとれにくく歩行時に洗 浄液がゆれて点滴台が押しづらい。

(2)歩行時に点滴台と尿バッグを持たなければ ならない為、両手がふさがり不自由である。 実際には、尿バッグを着物の腰ひもにかけた り、点滴台の高さの調節ねじの部分にかけた りと患者自身で工夫していたが、これでは尿

後清美尾神正子

（廣島総合病院 泌尿器科病棟）

バックが患者の膀胱レベルより高くなり、逆 流感染及び尿流出を妨げる恐れがあった。 (3)排便時に尿バッグの置き場所がわからず、 㦿においたり手すりにぶらさげたりしたとい う意見があり、不潔になったりカテーテルを 不必要に引っぱってしまう危険があった。 (4)体動時に洗浄液から輸液セットがはずれた り、カテーテルと輸液セットがはずれたりと いう事実があり、患者の不安や不快感を招い たり、看護婦側としてあ尿量の算出が不正確 になると共に感染性が高くなる危険があった。 (2)工夫の実際と評価

〈問題点(1)について〉

洗浄液を点滴台に固定する為、幅 $3 \mathrm{~cm}$ のゴ ムの両端にマジックテープをつけたものを固 定バンドとして利用した。点滴台も 4 本足の あのを利用した。その結果、患者からも「ゆ れはほとんぞ感じなかった」「歩行しやすか った」という意見があり、洗浄液のゆれは軽 减でき、歩行あスムーズになったと考える。

〈問題点 (2)と (3)について〉

片手が必ず自由に使えるように、尿バッグ を点滴台の適切な高さに固定できるものとし て市販のハンガーを尿バッグ掛けとして利用 した。その際、尿バッグは患者の膀胱レベル より低くするが休にはつかない位置にする必 要があり、尿バッグ掛けを直接点滴台の持ち 手にぶらさげると高すぎる為、ひもで調節す る必要があった。この尿バック掛けの使用に より、患者は片手で点滴台を押すのみでょく 反対側の手は自由に使えるようになり、排便 
時に尿バッグの置き場所に困るという意見は きかれなくなった。

〈問題点 (4)について〉

洗浄液から輸液セットがはずれ落ちないよ

う、I V H セットについている固定用テープ を同じ方法で再利用した。カテーテルと輸液 セットの接続のはずれ防止には、接続部分を 細い布絆創膏でらせん状に巻き固定した。そ の際、布紏創高の巻き始めと巻き終りは少し ずつ折っておき、はがしやすいようにした。 その結果、洗浄液から輸液セットがはずれた 例が 1 例あったが、固定用テープがあった為 はずれ落ちることはなく、カテーテルと輸液 セットの接続がはずれた例む 1 例のみであっ た。

\section{4. 考 察}

持続膀洗中の患者の苦痛の軽減を図り、事 故防止に留意しながら、患者がより安全に安 楽に日常生活を送れるようにと考えこの研究
に着手した。経費の面あ考慮し、あえて身近 にあるあのを利用して工夫を試みた。 持続膀洗を行っていた患者は60〜70歳が全体 の77\%を占め、高齢者が多い中、特に歩行開 始後の患者の移動について考えたことで、よ り早期離床を促せたのではないかと思う。

看護婦側としては、洗浄液の交換の際、今 までなかった固定バンドやテープのとりつけ がある為能率は悪くなったが、患者の苦痛を 最少限にでき、事故防止につながったと考え れば、今回の研究の成果はあったと思う。

\section{5. おわりに}

今回のアンケート調査から私達は、患者に より快適な入院生活をと目指しているものの、 つい見逃している苦痛や不快感、羞恥心に改 めて気づいた。すべてについて解決すること はできなかったが、残された問題点について は今後の課題として、援助方法を検討してい きたいと思う。 


\section{3 在宅医療における泌尿器科医の役割}

○市川晋一（仙北組合総合病院泌尿器科）

はじめに：当院では、通院困難で、尿道カ テーテル留置の寝たきり老人患者に、カテー テル交換を主とし、尿路管理を指導するため に泌尿器科医が訪問看護と同時に訪問診療を 行っている。今回私は泌尿器科医の在宅医療 の意義について検討したので報告する。

対象及び方法：昭和 62 年 4 月より平成 4 年 12月まで、対象（表 1) は当院診療圈（図 1) である秋田県大曲市、仙北郡内の脳血管障害、 脊髄疾患、癌末期、老衰で寝たきりで、在宅 医療を希望し通院困難な患者 27 名である。本 人、家族の希望または主治医の要請があれば 当院在宅ヶア委員会（図 2 ) の検討後、泌尿 器科医が主治医または地域の開業医や病院や 市町村保健課に連絡して、看護婦と月 $1 \sim 2$ 回訪問している。診療内容は全身の診察、カ テーテル交換、膀胱洗浄指導、裖創予防特よ び家族よりの情報収集と話し合いなどである。 結果：年令は 58～91才 (平均 71.1 才)、 男性 20 名 $(74 \%)$ 、女性 7 名 $(26 \%)$ で、高 齢の男性が多い。原疾患は、脳血管障害 18 例 $(66.7 \%)$ 、前立腺癌 4 例、膀胼癌 2 例、脊 髄疾患 2 例、老衰 1 例である。排尿障害の原 因は神経因性膀脱 20 例 ( 74\%)、癌 6 例、前 立腺肥大症 1 例である。在宅の契機は、退院 後の継続として26例（ $92.3 \%)$ が多い。理由 は、在宅を積極的に希望した患者14例（51.9 $\%$ )、通院困難 7 例（ $26 \%$ )、癌末期で在宅 死を希望したもの 6 例（22.2\%)である。主 たる介護者は、伴侶 17 例 $(63 \%)$ と妻が圧倒 的に多く、子どもは 6 例 ( $22.6 \%)$ で、嫁は

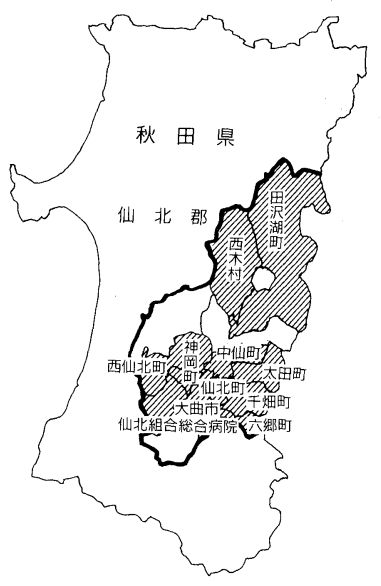

図 1. 訪問診療地域

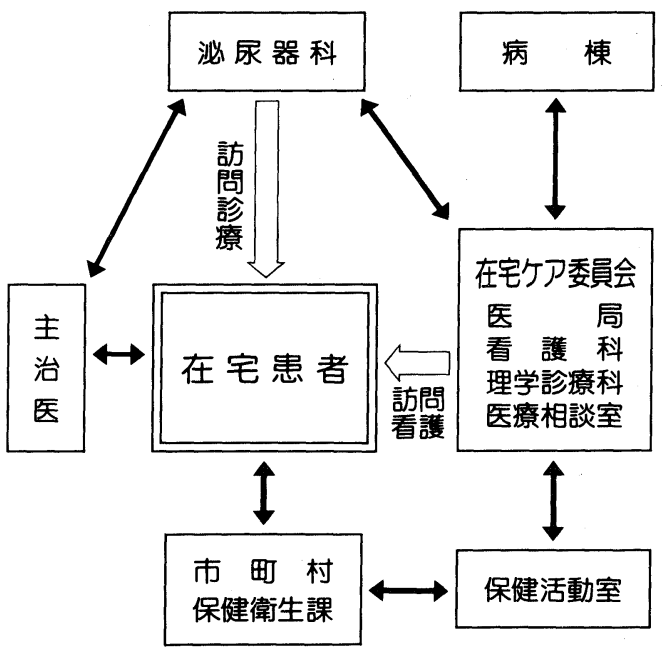

図 2. 当科の在宅ヶアシステム

1 例と極めて少ない。住所は大曲16 例（59.3 \% ) と市内が多い。距離は 1 50kmで、冬期 車で片道 1 時間以上もかかることがある。

尿道カテーテル留置しているものが 25 例 ( $22.6 \%)$ で、それゆえに泌尿器科医が訪問診 療を依頼されていることもある。褛創がある ものが 10 例 ( $37 \%)$ で、在宅で再入院の最大 
の原因となっている。経過は死亡例19例（ 70 .

$4 \%$ )、継続中 8 例 ( $29.6 \%)$ である。

考察：尿道カテーテル留置はなるべくさけ たいが、訪問患者は入院中尿失禁や排尿障害 を理由に尿道カテーテルを留置され、退院後 のカテーテル交換を当科に紹介されたものが
ほとんどである。また在宅死を希望する癌末 期患者に対して除痛を主にして援助している。 在宅では、尿路管理に家族も戸惑らことが多 く、尿路合併症が致命的となる場合もあり、 在宅医療を継続するためには泌尿器科医とは いえ訪問診療を行らべきであると考えられる。

表 1 患者背景

\begin{tabular}{|c|c|c|c|c|c|c|c|c|c|c|}
\hline 症例 & 患 者 & $\begin{array}{l}\text { 住㰤 } \\
(\mathrm{Km})\end{array}$ & 主疾患 & 合併症 & 主治医 & 介護者 & 期間 & $\begin{array}{l}\text { 尿道 } \\
\Delta \bar{T}-\bar{T} N\end{array}$ & 嘘創 & 副 経過 \\
\hline 1 & 58 女 & $\begin{array}{c}\text { 大曲市 } \\
1.5 \\
\end{array}$ & 脳出血 & 神経因性膀胱 & 内科 & 夫 & $\begin{array}{l}\mathrm{S} 62.4 \\
-\mathrm{H}=\mathrm{\tau} .11\end{array}$ & 0 & $x$ & $\begin{array}{r}\text { 脳出血で } \\
\text { 死亡 }\end{array}$ \\
\hline 2 & 78 女 & $\begin{array}{c}\text { 大曲市 } \\
2.5\end{array}$ & 脳梗塞 & 神経因性膀腃 & 内科 & 家政婦 & $\begin{array}{l}562.1 \\
-63.1 \\
\end{array}$ & 0 & $x$ & $\begin{array}{l}\text { 脳梗塞で } \\
\text { 死亡 }\end{array}$ \\
\hline 3 & 71 男 & $\begin{array}{c}\text { 仙北町 } \\
4.0\end{array}$ & 脳出血 & 神経因性膀胱 & 内科 & 妻 & $\begin{array}{l}\$ 62.4 \\
-62.8\end{array}$ & $\mathrm{O}$ & O & 肺炎で死亡 \\
\hline 4 & 90 男 & $\begin{array}{c}\text { 太田町 } \\
40\end{array}$ & 老衰 & 前立腺肥大症 & 開業医 & 妻 & S62. 9 & 0 & $x$ & 教衰で死亡 \\
\hline 5 & 80 男 & $\begin{array}{c}\text { 西木村 } \\
40 \\
\end{array}$ & 脳梗塞 & 神経因性膀胱 & 開業医 & 妻 & $\begin{array}{l}S 62.11 \\
-63.1 \\
\end{array}$ & 0 & $O$ & $\begin{array}{r}\text { 心不全で } \\
\text { 死亡 }\end{array}$ \\
\hline 6 & 77 男 & $\begin{array}{c}\text { 大曲市 } \\
1.5\end{array}$ & 脳梗塞 & 神経因性膀脂 & 内科 & 妻 & S63.3 & $\mathrm{O}$ & $x$ & $\begin{array}{r}\text { 開業医に } \\
\text { 要更 }\end{array}$ \\
\hline 7 & 79 男 & $\begin{array}{c}\text { 大曲市 } \\
3 \\
\end{array}$ & 脳梗塞 & $\begin{array}{l}\text { 神経因性膀哓 } \\
\text { 前立腺肥大症 }\end{array}$ & 内科 & 妻 & $\begin{array}{c}\mathrm{S} 63.10 \\
\sim 11\end{array}$ & $\mathrm{O}$ & $x$ & 施設入所 \\
\hline 8 & 72 男 & $\begin{array}{l}\text { 六郷町 } \\
6 \\
\end{array}$ & 脳梗塞 & 神経因性膀胱 & 内科 & 妻 & $\begin{array}{l}\text { H2.3 } \\
\text { H3. } 10\end{array}$ & 0 & 0 & 肺炎で死亡 \\
\hline 9 & 71 女 & $\begin{array}{c}\text { 大曲市 } \\
1\end{array}$ & 脳梗塞 & 神経因性膀脂 & 内科 & 義妹 & $\begin{array}{l}\text { H2. 4 } \\
\text { H3. } 10\end{array}$ & $\mathrm{O}$ & $\mathrm{O}$ & $\begin{array}{r}\text { 脳便塞で } \\
\text { 死亡 }\end{array}$ \\
\hline 10 & 78 男 & $\begin{array}{c}\text { 大曲市 } \\
4\end{array}$ & 脳梗塞 & 神経因性膀㬶 & 開業医 & 娘 & $\begin{array}{r}\mathrm{H} 3.3 \\
\sim 8\end{array}$ & $\mathrm{O}$ & 0 & $\begin{array}{r}\text { 心不全て } \\
\text { 死亡 }\end{array}$ \\
\hline 11 & 77 男 & $\begin{array}{c}\text { 大曲市 } \\
2\end{array}$ & 脳梗塞 & $\begin{array}{l}\text { 神経因性膀脱 } \\
\text { 前立腺肥大症 }\end{array}$ & 開業医 & 妻 & $\begin{array}{r}\mathrm{H} 3.6 \\
-8 \\
\end{array}$ & $\mathrm{O}$ & O & \begin{tabular}{|c} 
脳梗塞で \\
死亡
\end{tabular} \\
\hline 12 & 71 男 & $\begin{array}{c}\text { 大曲市 } \\
2\end{array}$ & $\begin{array}{l}\text { 脊椎管 } \\
\text { 狭窄症 }\end{array}$ & 神経因性膀胱 & 内科 & 妻 & $\begin{array}{l}\mathrm{H} 3.10 \\
-\mathrm{H} 4.4\end{array}$ & $\mathrm{O}$ & 0 & 肺炎で死亡 \\
\hline 13 & 91 男 & $\begin{array}{c}\text { 中仙町 } \\
30\end{array}$ & 脳梗塞 & $\begin{array}{l}\text { 神経因性膀脂 } \\
\text { 前立腺肥大症 }\end{array}$ & 内科 & 妻 & $\begin{array}{l}\text { H3. } 11 \\
-H 4.8\end{array}$ & $\mathrm{O}$ & 0 & 肺炎で死亡 \\
\hline 14 & 64 男 & $\begin{array}{c}\text { 大曲市 } \\
4\end{array}$ & 脊損 & $\begin{array}{l}\text { 神経因性膀脂 } \\
\text { 尿道狭窄 }\end{array}$ & 内科 & 妻 & S63. 8 & $\mathrm{O}$ & $x$ & 継続中 \\
\hline 15 & 68 男 & $\begin{array}{c}\text { 千畑町 } \\
15\end{array}$ & 脳梗塞 & $\begin{array}{l}\text { 神経因性膀胱 } \\
\text { 尿道狭窄 }\end{array}$ & 内科 & 妻 & S63.11 - & $\mathrm{O}$ & 0 & 継続中 \\
\hline 16 & 74 男 & $\begin{array}{c}\text { 大曲市 } \\
4\end{array}$ & 脳梗塞 & 神経因性膀脂 & 内科 & 妻 & $\mathrm{H}=5$ & $\mathrm{O}$ & 0 & 継続中 \\
\hline 17 & 48 男 & $\begin{array}{c}\text { 大曲市 } \\
4\end{array}$ & 脳梗塞 & 神経因性膀胱 & 内科 & 母親 & $\mathrm{H} \overrightarrow{\mathrm{z}} .10^{-}$ & 0 & $x$ & 継続中 \\
\hline 18 & 86 男 & $\begin{array}{c}\text { 大曲市 } \\
1\end{array}$ & 脳梗塞 & $\begin{array}{l}\text { 神経因性膀胱 } \\
\text { 前立腺肥大症 }\end{array}$ & 内科 & 息子 & H2. 10 & $\mathrm{O}$ & $x$ & 継続中 \\
\hline 19 & 65 女 & $\begin{array}{c}\text { 太田町 } \\
20\end{array}$ & 脳梗塞 & 神経因性膀脒 & 内科 & 娘 & H2.11 & $\mathrm{O}$ & $x$ & 継続中 \\
\hline 20 & 69 男 & $\begin{array}{c}\text { 大曲沛 } \\
5\end{array}$ & 脳梗塞 & 神経因性膀胱 & 内科 & 妻 & H3. 11 & $\mathrm{O}$ & 0 & 継続中 \\
\hline 21 & 82 女 & $\begin{array}{c}\text { 大曲市 } \\
2\end{array}$ & 脳梗塞 & 神経因性膀脂 & 内科 & 娘 & H4. 3 & $\mathrm{O}$ & $x$ & 継続中 \\
\hline 22 & 79 男 & $\begin{array}{c}\text { 田沢湖町 } \\
50 \\
\end{array}$ & 前立腺䍄 & 全身転移 & 当科 & 妻 & S63. 3 4 & $\mathrm{O}$ & $x$ & $\begin{aligned} \text { 再入院し } \\
\text { 死亡 }\end{aligned}$ \\
\hline 23 & 77 女 & $\begin{array}{c}\text { 大曲市 } \\
4\end{array}$ & 膀胱癌 & 脳出血 & 当科 & 娘 & H3. $8 \sim 12$ & $\mathrm{O}$ & $x$ & 自宅で死主 \\
\hline 24 & 80 男 & $\begin{array}{c}\text { 千畑町 } \\
10\end{array}$ & 前立腺癔 & 脳梗塞 & 当科 & 娘 & H4. 4 & $x$ & $\mathrm{O}$ & 自宅で死式 \\
\hline 75 & 78 男 & $\begin{array}{c}\text { 神岡町 } \\
8\end{array}$ & 前立腺㷎 & 全身転移 & 当科 & 妻 & H4. 4 & $\mathrm{O}$ & $x$ & 自宅で死亡 \\
\hline 26 & 72 女 & $\begin{array}{c}\text { 西仙北町 } \\
30\end{array}$ & 膀㬶癌 & 全身転移 & 当科 & 娘 & H4. 5 7 & $x$ & $x$ & 自宅で死云 \\
\hline 27 & 79 男 & $\begin{array}{c}\text { 大曲市 } \\
4\end{array}$ & 前立腺稍 & 全身軽移 & 当科 & 妻 & H4. 6 & 0 & $x$ & 自宅で死主 \\
\hline
\end{tabular}




\section{産婦人科疾患・乳腺疾患}

$1 \mathrm{~J} 09$ 異常乳頭分泌を呈する非触知乳癌へのアプローチ

平鹿総合病院外科, 同病理 *

○寺島秀夫, 松岡富男, 島田友幸, 大倉一雄 *

\section{【緒言】}

乳癌研究会集計によれば無腫袺性乳癌 ( $\mathrm{T}$

0 乳癌) nonpalpable Brest Cancerの発見契

機のうち、乳頭異常分泌の頻度が最も高く69 \%を占めている。従って、T0 乳癌発見の戦 略上、乳頭異常分泌は有用な情報を提供して くれるものと言えよう。異常乳頭分泌を主訴 とし腫瘤を触知せず、マンモグラフィー（M $M G) \cdot$ 超音波検查（US）にて腫瘤を誌め ない症例に対して、独自の戦略にて乳癌およ び前癌病変の発見に努めて来た。以下、その 成績および新たな知見について報告する。

\section{【方法】}

平成 4 年 5 月より平成 5 年 1 月までに乳頭 異常分泌を主訴として来院し、MMG・US にて腫瘤を認めない症例を対象とした。全例 において、(1)マンモテックR （カット・オフ 值 $400 \mathrm{mg} / \mathrm{ml}$ ）にて分泌液中C E Aを定性,

(2)蓄乳細胞診（一日 3 回計 5 日間蓄乳）を行 った。以上の結果にて、(1)細胞診の結果にか かわらずCEA 1000 ng/ml であり、かつ分 泌が単孔性, (2)C E A $400 \mathrm{ng} / \mathrm{ml}$ であり、細 胞診にてclass III 以上，の症例に対して乳管 造影を原則的に施行した。乳管造影で乳管の 陰影欠損・狭小化・途絶・率裂等の悪性所見 を認めた場合は、microdochectomy を行う方 針とした（悪性の場合は根治術）。

\section{【結果】}

総数58人の患者が受診した。年齢分布は 33 歳〜67歳で、平均年歯は46.4 )であった。両側性の乳頭分泌は29例（50\%）
に認められた。異常乳頭分泌の乳房数は延べ 88乳房であった。

1 ) 分泌夜中 C E A 值と蓄孚細胞診の関係 表 1 に示した。

2 ）分泌液の性状 血性例の C E A 值 - 細胞診・摘出標本の病 理診断を表 2 に総括した。

3 ）分泌液中C E A $1000 \mathrm{ng} / \mathrm{ml}$ 症例（表 3 ） 32乳房中、細胞診 classIVの一乳房と分泌 が多孔性であった 7 乳房（細胞診 class II 以 下）そして分泌がごく少量で細胞診および乳 管造影を施行し得なかった 2 乳房を除く、22 乳房に対して乳管造影を施行した。乳管造影 にて悪性所見が疑われた 3 乳房にmicrodochectomyを行った（表4）。残り19乳房の 乳管造影で11乳房 $(57.9 \%$ ) が囊胞・乳管拡 張を示したが、他 8 乳房では特に所見は認め られなかった。

4) 分泌液中CEA $400 \mathrm{ng} / \mathrm{ml}$ 症例

細胞診で class III を示した 4乳房に乳管造 影を行い悪性を示唆する所見を認めたため、 microdochectomyを施行した（表4）。

また、カット・オフ値の意味を探る上で、 細胞診 class II 以下の症例に対してランダム に（8乳房）乳管造影を行った。1乳房に途 絶様の所見を認めたため、microdochectomy を行った（表4）。6乳房 $(6 / 7,85.7 \%)$ が、 囊胞・乳管抎張を示した。

5 ）最終診断および手術（表 5 ）

\section{【結語】}

(1)無腫瘤性の異常乳頭分泌患者 58 人のうち、 
早期乳癌は 1 人 $1.7 \%$ であった。

(2)Microdochectomyが 7 症例に施行されたが、 そのうち 5 例が癌化の可能性の高い病態にあ つた。Microdochectomy の適応基準を乳管造 影に所見を認め、C E A $1000 \mathrm{ng} / \mathrm{ml}$ またはC E A400 ng/miかつ細胞診class III 以上とする と正診率は $83 \%$ となった。乳癌を予防する上 で、前癌状態で切除しておくことが最も有効 であり、以上の基準にて積極的に Microdochetomyを行うべきと考えられた。

(3)血性乳頭分泌を認めた場合、悪性の可能性 が高い否か一次スクリーニングを施行する上 でC E A 值が有用である。

(4) C E A 值 $200 \mathrm{ng} / \mathrm{ml}$ 症例はすべて細胞診 が class I ・IIであり、同値の場合は蓄乳細 胞診を省略できることが示唆された。

(5)カット・オフ值を越え、細胞診がclass II 以下で乳管造影で悪性を示唆する所見がない 症例では高頻度で囊胞・乳管拡張が認められ た。従って、このような症例では震胞内で $\mathrm{C}$ E Aが濃縮され乳頭より分泌される結果、偽 陽性を呈する可能性が示唆された。

(5)当施設の異常乳頭分泌に対するアプローチ を図1にまとめた。

\begin{tabular}{|c|c|c|c|c|c|}
\hline \multirow{2}{*}{$\begin{array}{c}\text { 分泌液中C E A } \\
(\mathrm{ng} / \mathrm{ml})\end{array}$} & \multirow[t]{2}{*}{ 乳房数 } & \multicolumn{3}{|c|}{ 萻乳湅胞韵 class } & \multirow[b]{2}{*}{ V } \\
\hline & & $1 \cdot 11$ & III & IV & \\
\hline 1000 & $\begin{array}{c}32 \\
(36.4 \%)\end{array}$ & 30 & 1 & 1 & 0 \\
\hline 400 & $\begin{array}{c}37 \\
(42.0 \%)\end{array}$ & 33 & 4 & 0 & 0 \\
\hline \multirow[t]{2}{*}{200} & $\begin{array}{c}19 \\
(21.6 \%)\end{array}$ & 19 & 0 & 0 & 0 \\
\hline & 88 & 82 & 5 & 1 & 0 \\
\hline
\end{tabular}

表 2 血性分泌液症例 $(8.6 \%, 5 / 58$ 例)

\begin{tabular}{|c|c|c|}
\hline 診断 & 耕胞梧 class & $C E A$ 值 (mg/mi) \\
\hline 非浸洞性乳管螷 & IV & 1000 \\
\hline 管内乳頭曆 & 11 & 1000 \\
\hline 乳頭腫应 & II & 1000 \\
\hline \multirow[t]{2}{*}{ 経過翻察 } & $\|$ & 400 \\
\hline & 1 & 200 \\
\hline
\end{tabular}

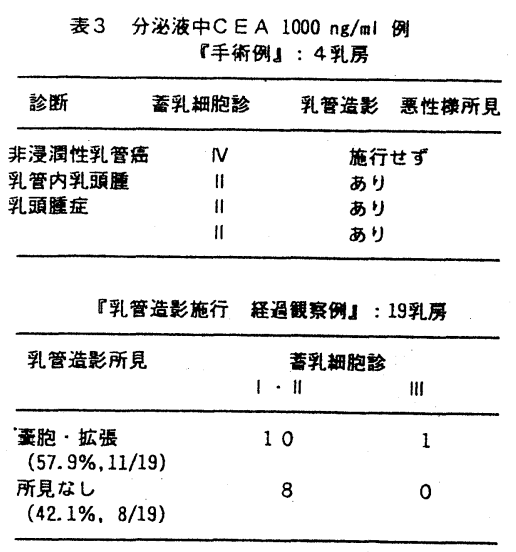

表4 Microdochectomy 症例

\begin{tabular}{|c|c|c|c|c|}
\hline 症例 & 年齫 & 分泌液中CEA & 蓄乳耕胞診 & 診断 \\
\hline 1 & 37 & $1000 \mathrm{mg} / \mathrm{ml}$ & $\|$ & 乳管内乳頭稫 \\
\hline 2 & 40 & 1000 & $\|$ & 乳頭腫应 \\
\hline 3 & 44 & 400 & III & 乳頭堹应 \\
\hline \multirow[t]{2}{*}{4} & 35 & 右 400 & III & ともにsecretory \\
\hline & & 左 400 & III & lobular change \\
\hline 5 & 65 & 1000 & $\|$ & 乳頭腫症 \\
\hline 6 & 41 & 400 & III & 乳頭腫症 \\
\hline 7 & 50 & 400 & $\|$ & アポクリン化生 \\
\hline
\end{tabular}

表 5

異常乳頭分泌を主訴に来院した患者数：58名 (1)乳癌 : 1 人 $(1.7 \%)$

非浸潤性乳管癌, Iy 0 v0 n 0

(術式: 乳腺全切除+Level III リンパ節郭清+ 腹直筋皮弁による乳房再建)

(2)癌化の可能性高い病態 : 5 人 $(8.6 \%)$

管内乳頭腫 : 1

乳頙腫症: 4

(術式: Mi crodochect omy)

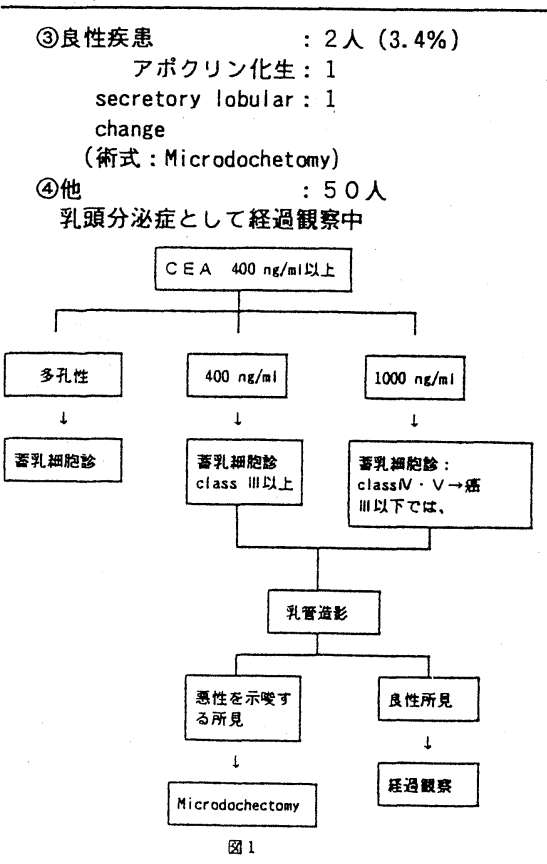


○吉村多香美・井上みのり・川村 極・中川 訓江

野田 勉・山本 悟・樫木 良友 (岐阜県 岐北総合病院)

【目的】乳癌は今後ますます増加し、女性の 癌では第一位になることが予測されている。 乳癌は乳房切除という外見的変化のみならず、 病名を告知されることが、他の癌に比して多 く、そのため患者の再発に対する潜在的恐怖 心には測り知れないものがある。そこで我々 は、乳癌術後患者の身体的および精神的不安 感を知る事により、今後の保健活動の方向を 検索しようと試みた。

【対象および方法】平成 5 年 2 月26〜27日の 温泉旅行参加者79名に無記名アンケート形式 で調査した。患者の平均年齢は53歳で内 4 名 が部分切除を受けていた。回答は63名であっ た。

\section{【結 果】}

1. 身体的評価 30 名 (47.6\%) が何らかの 身体的変化あるいは不安感を訴えた。体重増 加11名 (36.6\%) が最も多く、次いで生理不 順 6 名 (20.0\%) 、易疲労感 6 名 (20.0\%) の順であった。（図 1)

2. 精神的評価 39 名 (61.9\%) が何らかの 精神的不安感を持っていた。再発12名（30.7 $\%$ ）転移 6 名 (15.3\%) と 18 名 (46.0\%) が 原疾患之密接な死に対する潜在的恐怖心を訴 えた。(図 2 )

3 . 家庭内援助 22 名 (34.9\%) が家庭内で 身体的精神的援助を受けていた。（図 3 ）

4. 相談相手 複数回答での結果であるが、 夫15名、姉妹15名、娘 7 名之相談相手が家族 であるものが最も多く、次いで友人 9 名で医
療スタッフでは主治医と答えたものがわずか 3 名で、保健婦あるいは看護婦との回答はな かった。

【考察】乳癌術後患者の最大関心事は、再発 転移に関するもので、整容的なるのは二次的 であった。最近の縮小手術法により乳房が温 存されたり、胸筋温存により患肢の機能障害 が少なくなり、日常生活の場における不自由 感を訴えるものが少なかった。多くの回答が 得られた体重增加であるが、内分泌療法によ る影響は無視できないむのの、むしろ「無理 をすると再発する」という精神的不安感から 運動不足に陥り、結果としての体重増加とい う身体的変化を惹起したものと考えられた。 時々自覚する軽微な疼痛についても、再発と 結び付けて不安感に駆られることが多く、患 者同士の交流や、主治医からの説明で再発と は無関係なこと、或いはそれは多くの人が経 験していることなどを理解することにより、 精神的不安感から解放された。

術後患者の交流関係を分析すると、従来か らの友人よりも入院中に知り合ったり通院中 に知り合った友人との親密な交際関係を持っ ているものが多かった。即ち、「共通の体験 をした」という結びっきは強く、お互いの交 流でもって相互扶助し不安感を「昇華」して いた。

今後の保健活動を行っていく方向として、 我々自身も患者と密な交流を保ち、患者の精 神的不安感に対する情報を詳細に把握し、か つ、患者同士の交流の機会を可及的便宜を図 
り、側面から、特に精神的援助を行うのが重 要であると考えた。このような試みの一つの 方法として、患者の精神的肉体的緊張の解放 を目指した「医療スタッフと共の温泉旅行」 は大変意義のあることと考える。
【まとめ】乳癌患者の身体的不安感は再発等 に対する精神的不安感からに起因することが 多く、保健活動の方向としては、精神的不安 感に対して側面から援助を行う必要がある。 患者との交流を密にして、可及的「本音」の 情報を把握し、今後の保健指導に生かすこと、 患者同士の交流の機会にできるだけ便宜を図 ることが重要である。
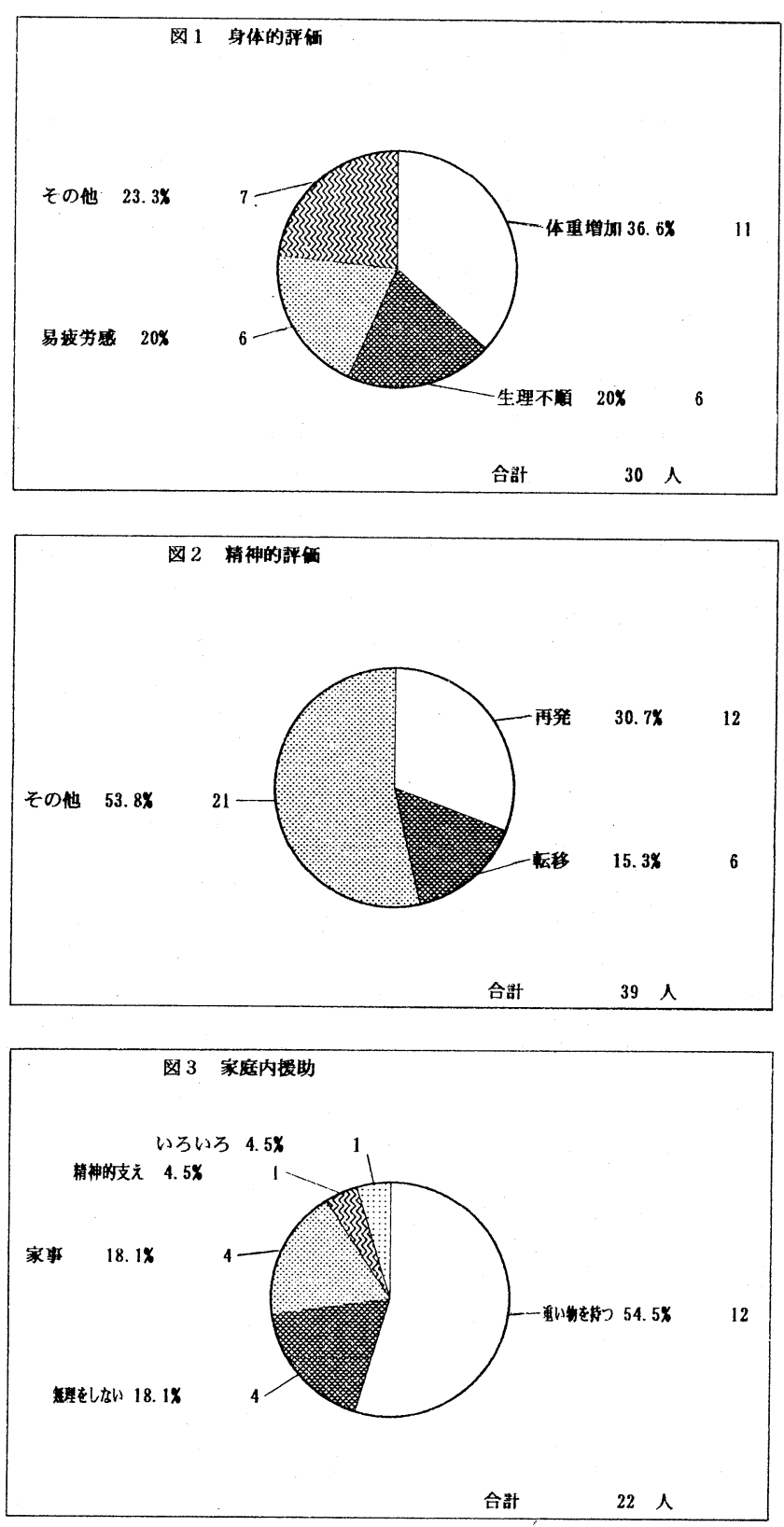
1J11一次スクリーニング超音波検査を用いた
施設乳癌検診および巡回乳癌検診の現状

○飛田公博 中村恭世 野田紀久美 小野理津子 小野洋子 石川よしみ 甲斐俊一坪井峯男

（大分県農村健康管理センタ一）

くはじめに> 当センターでは施設総合健診 における乳癌検診を、平成元年 4 月より超音 波検查法を用いて施行してきた。また同年10 月より超音波検診車をつくって巡回乳房超音 波検診をスタートさせた。今回この 4 年間の 検診結果を比較したので報告する。 <対象及び方法＞施設検診では、この間に 当センターを受診した延べ 23,752 人の女性全 員を対象とした。また巡回検診では平成 3 年 度までは農協が単独で募集した女性を対象と したが、平成 4 年度からは市町村が実施主体 となり、胃集検、子宮癌検診などと一緒に実 施するようになった。

方法は、施設検診では医師がすべて超音波 検查をおこない、巡回検診では検查技師がプ ローブを持ち、医師は触診しながらダブルチ ェックができるようにした。記録はV T R は 用いず光ディスクに左右 3 断面ずつ撮影した。 検查に要した時間は 1 人 $4 \sim 5$ 分であった。 超音波検查で腫瘤像を認めたものに対して、 当日、超音波ガイド下に穿刺吸引細胞診を施 行し、結果は数日以内に電話で通知した。穿 刺に際しては、穿刺用アダプターは用いず、 延長チューブに接続した $22 \mathrm{G}$ 注射針を術者が フリーハンドに担持し、小病巣をねらい易く した。次に細胞訬の結果がC1ass III 以上のも の、または超音波所見で悪性所見がみられる ものを三次検診（主に外科的生検）の適応と した。

<結果及び考察> 受診者（表 1) は、施設 検診が延べ23,752人、巡回検䛦は 11,413 人、
年代別では施設、巡回とも50才代が最も多 く、次いで60才代、40才代の順であった。 巡回検診を農協単独で実施していた平成 3 年度までと、市町村を実施主体とした平成 4 年度に分けて表 2 に示す。

施設検診の結果は、1日あたりの実施人数 23.8 人、超音波で腫瘤像を認め二次検査とな ったものは 363例（要精検率 1.5\%) で、こ のうちから25例の乳癌が発見された（癌発見 率0.11）。巡回検診は 1 日あたり 50.5 人、二 次検查の対象となったものは 344人（要精検 率 $3.0 \%$ ）、乳癌発見数18例（癌発見率0.16） であった。また巡回検診を平成 3 年度までと 4 年度之で分けてみると胃集検や子宮癌検診 と一緒に実施するようになって検診効率が著 しく良くなっている。

次に二次検查（穿刺吸引細胞診）の対象亡な った病巣部を $5 \mathrm{~mm}$ きざに大きさ別に表 3 に 示す。施設検診、巡回検診とも 6 $10 \mathrm{~mm}$ が最 も多く半数近くを占め、次いで11 15mmが多 く、この 6〜 15mmの病巣が全体の $76 \%$ を占め た。また、施設検診で発見された乳癌25例中 22例 $(88 \%)$ 、巡回検診での18例中11例（61 $\%$ ）、はこの比較的小さい病巣より発見され た。穿刺は、のう胞を穿刺した経験から大き さ $5 \mathrm{~mm}$ 程度でも確実におこなえるものと確信 した。

次に、T分類の比較を表 4 に示すが、巡回 検診で $\mathrm{T}_{2}$ が 2 例発見されたが最大径 $2.5 \mathrm{~cm}$ の比較的小さい $\mathrm{T}_{2}$ であった。（T。）の中 には超音波で描出しながら触診するとかろう 
じて触知するがはじめから触診しただけでは、 触知できなかったであろうと思われるものも 含めた。触診では困難でも、超音波検査では、 存在診断は比較的容易であった。次に細胞診 の結果を表 5 に示す。このうちから、施設検 診でClass III以上54例、巡回検診ではClass II の 1 例を加えて49例中47例の合計 101例に、 外科的生検查が施行された。生検の結果、良 性疾患だった病変のうちわけは、乳腺症 41 例、 線維腺腫11例、乳管内乳頭腫 1 例、のう胞内 腺腫 1 例、異常なし 4 例であった。乳腺症と の鑑別診断は困難な例が多かった。発見され た乳癌43例の組織型を表 6 に示す。

＜結語 > 乳癌検診の効率を高めるためには、 超音波検查法は有効な手段である。

$\mathrm{T}_{1}$ 症例の 10 年生存率がほぼ $90 \%$ に達して いることから必ずしもT。乳癌にこだわるこ となく $T_{1}$ 症例をもっと効率良く発見する努

表 1 年代別受診者数

\begin{tabular}{|r|r|r|}
\hline 年代別 & 施 設 検䧐塾 & 巡 回 検 彭 \\
\hline$\sim 29$ & $76(0.3)$ & $49(0.4)$ \\
\hline $30 \sim 39$ & $1,358(5.7)$ & $1,399(12.3)$ \\
\hline $40 \sim 49$ & $5,352(22.5)$ & $2,605(22.8)$ \\
\hline $50 \sim 59$ & $8,646(36.4)$ & $3,531(30.9)$ \\
\hline $60 \sim 69$ & $6,895(29.0)$ & $3,087(27.0)$ \\
\hline $70 \sim$ & $1,425(6.0)$ & $742(6.5)$ \\
\hline 合 計 & $23,752(100)$ & $11,113(100)$ \\
\hline
\end{tabular}

( ) $\%$

表2施設検彭之巡回検診の結果比較

\begin{tabular}{|c|c|c|c|c|}
\hline & 施 設 検 彭 & 巡回 & 検 & 計 \\
\hline 期 & H. $1.4 \sim$ H. 5.3 & H. $1.10 \sim$ H. 4.3 & H. $4.4 \sim$ H. 5.3 & \\
\hline 1 日平均 & 23.8 人 $/$ 日 & 48.8 & 51.8 & 50.5 \\
\hline 延べ受診者 & 23,752 人 & $4, \quad 681$ & 6,732 & 11,413 \\
\hline 要精検者数 & 363 人 & 148 & 196 & 344 \\
\hline 要精検 率 & 1. $5 \%$ & 3. 2 & 2. 9 & 3. 0 \\
\hline 発見乳癌 & 25 例 & 3 & 15 & 18 \\
\hline 癌発見率 & $0.11 \%$ & 0.06 & 0.22 & 0.16 \\
\hline
\end{tabular}

力をすることが重要と思われる。トレーニン グを積んだ検查技師による検查でも病変部の 拾い上げ能に差はなく、腹部超音波検診と同 じように技師による乳房超音波検診も現実的 で有効な方法と思われる。

表 3 細胞診の対象となった病変部の大きさ

\begin{tabular}{|c|c|c|c|}
\hline 大きさ & 施設検猃 & 巡回検影 & 合 \\
\hline$\sim 5 \mathrm{~mm}$ & 26 & 33 & 59 \\
\hline $6 \sim 10$ & 176 (11) & $169(4)$ & 345 (15) \\
\hline $11 \sim 15$ & 100 & $93(7)$ & 193 (18) \\
\hline $16 \sim 20$ & $24(2)$ & $33(5)$ & $57(7)$ \\
\hline $21 \sim 25$ & $9(1)$ & $10(2)$ & 19 ( 3$)$ \\
\hline $26 \sim 30$ & 6 & 5 & 11 \\
\hline $31 \sim$ & 3 & 1 & 4 \\
\hline びまん性 & 19 & 0 & 19 \\
\hline 合計 & $363(25)$ & 344（18） & 707 (43) \\
\hline
\end{tabular}

（）は乳癌

表 4 T分類比較

\begin{tabular}{|c|c|c|c|c|c|}
\hline & $\mathrm{T}$ is & $(\mathrm{T} 0)$ & $\mathrm{T}_{1}$ & $\mathrm{~T}_{2}$ & 乳癌例数 \\
\hline 施設検診 & 1 & 8 & 16 & 0 & 25 \\
\hline 巡回検讋 & 2 & 6 & 8 & 2 & 18 \\
\hline
\end{tabular}

表 5 細胞䧐の結果

\begin{tabular}{|c|c|c|c|c|c|}
\hline & I $\cdot$ II & III & $\mathrm{IV} \cdot \mathrm{V}$ & 判定不能 & 合 計 \\
\hline 施設検診 & $\begin{array}{c}295 \\
(1)\end{array}$ & $\left(\begin{array}{l}27 \\
(3)\end{array}\right.$ & $\begin{array}{c}27 \\
(21)^{7}\end{array}$ & 14 & $\begin{array}{c}3633 \\
(25)\end{array}$ \\
\hline 巡回㭘診 & $\begin{array}{l}281 \\
(1)\end{array}$ & $\begin{array}{l}28 \\
(1)\end{array}$ & $\begin{array}{c}20 \\
(16)\end{array}$ & 15 & $\begin{array}{c}344 \\
(18)\end{array}$ \\
\hline
\end{tabular}

表 6 発見乳癌の組織型

\begin{tabular}{|c|c|c|}
\hline & 施設検診 & 巡回検診 \\
\hline 非浸潤性乳管癌 & 2 & 2 \\
\hline 乳頭腺管癌 & 9 & 3 \\
\hline 充奏腺管癌 & 7 & 5 \\
\hline 硬 & 5 & 4 \\
\hline 粘 液 癌 & 1 & \\
\hline 戙棁 癌 & 1 & 1 \\
\hline 浸澗性小葉癋 & & 1 \\
\hline アポクリン癌 & & 1 \\
\hline 恶性リンパ腇 & & 1 \\
\hline 計 & 25 & 18 \\
\hline
\end{tabular}




\section{J12乳癌の胸骨傍リンパ節転移における超音波検査の検討}

$\begin{array}{ccc}\text { ○愛宕 } & \text { 博・野田 } & \text { 勉・田中 史朗 } \\ \text { 梅村 } & \text { 喜昭・末松 } & \text { 太・尾関 裕一 } \\ \text { 樫木 } & \text { 良友 (岐阜県 } & \text { 岐北総合病院 })\end{array}$

\section{I.はじめに}

日本における乳癌の発生率は年々いちじる しく増加の傾向にあり、それにより乳癌によ るリンパ節転移もふえてきている。リンパ節 転移の中で、腋窩リンパ節と鎖骨リンパ節は 体表より比較的容易に触知されるため、ある 程度それらの転移の有無老推定できるが、胸 骨傍リンパ節は胸壁に阻まれて全く触知不能 である。しかし、この胸骨傍リンパ節転移の 有無を術前・術後に診断することができれば 乳癌の予後、予測や手術式の選択などに極め て有用でありその意義は大きいと考元られる。 よって、今回我々は超音波を試み若干の知見 を得たので報告する。

\section{II. 方 法}

1) 使用装置

超音波装置：アロカ製 SSD-125

使用プローブ：アロカ製 $10 \mathrm{MHz}$ インライ

$$
\text { ンメカニカルセクタープローブ }
$$

\section{2 ）方法（検查手順）}

患者の背臥位とし患側を上方にする。内 胸陰性域は多くの場合、皮䖉から $2 \sim 3 \mathrm{~cm}$ 位のところにあり、矢状拉よび水平方向に より扢こなう。探触子と皮膚の間には充分 なゼリ一を塗布する。とくに乳房切除術後 の症例、胸骨の陥凹している症例はゼリー を多く塗り探触子を胸壁に押さえつけない で軽く走査する。走查方向は内胸陰性域の 長軸に沿って内より外側までを観察し、軽 度の異常が認められる場合はかならず対側 の内胸陰性域とくらべてその異常が生理的 なものか否かを対比する。明らかに異常が
認められた場合は水平走査とし、異常をダ ブルチェックする。

\section{III. 結 果}

(1)症例

33歳 女性 $\mathrm{H3}$ 年12月より左乳房のしこ りに気付くも放置、その後左腋窩部痛增強し 近医受診し、紹介にて当院外来受診した。超 音波・マンモグラフィーで左乳腺外側上部の 乳癌と診断し、胸骨傍超音波を施行した所、 左第 $2 \sim 3$ 肋間に $6 \times 7 \mathrm{~mm}$ の低エコ一像を認 めリンパ節転移と診断した。手術は拡大乳房 切除術を施行し、乳腺腫瘤は65 $\times 20 \mathrm{~mm}$ で、病 理組織唁断の結果乳頭腺管癌であり、stage IIIであった。又、手術前に診断した胸骨傍リ ンパ節以外にも $2 \sim 3 \mathrm{~mm}$ 大のリンパ節を認め た。

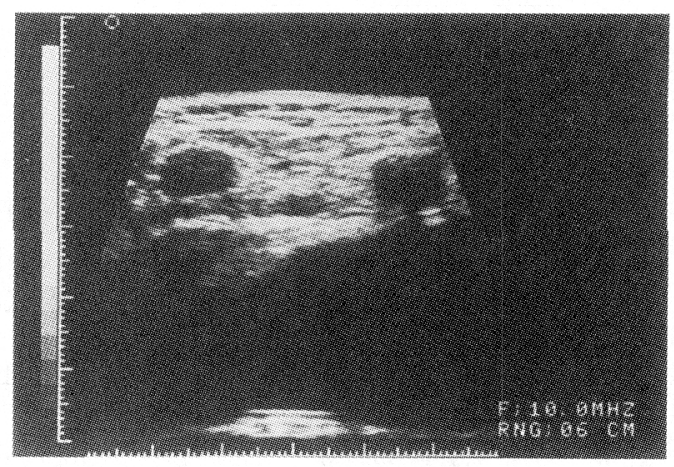

症例 1

(2)症例

34 歳 女性 H 2 年 9 月頃より左乳房のし こりに気付き当院外来受診。超音波・マンモ グラフィーで左乳腺内側上部の乳癌と診断し、 
胸骨傍超音波を施行した所、左第 $2 \sim 3$ 肋間 に限局性 8〜 $4 \mathrm{~mm}$ の低エコー像を認めた。摘 出した乳腺腫瘤は2 $5 \times 20 \times 25 \mathrm{~mm}$ で、病理組織 診断の結果乳頭腺管癌であり、stageIIであっ た。又、術前に診断した胸骨傍リンパ節以外 にも第 $1 \sim 2$ 肋間に $2 \mathrm{~mm}$ 大の腫瘤を認奻悇 した。



症 例 2

(3)症例

76 歳 女性 $\mathrm{H} 3$ 年前より右乳房腫瘤と腋 窩腫瘤に気付くもそのまま放置ししていた。 H 4 年に入り徐々に增大し近医受診し、紹介 にて当院外来受診した。超音波・マンモグラ フィーで右乳腺外側下部の乳癌と診断し、胸 骨傍超音波を施行した所、右第 $1 \sim 2$ 肋間に $10 \times 13 \mathrm{~mm}$ の限局性の低エコ一像を認め転移と 診断した。摘出した乳腺腫瘤は64×55 mm $\mathrm{T} 4 \mathrm{~b}$ 、病理組織診断の結果充実腺管癌であ り stageIVであった。

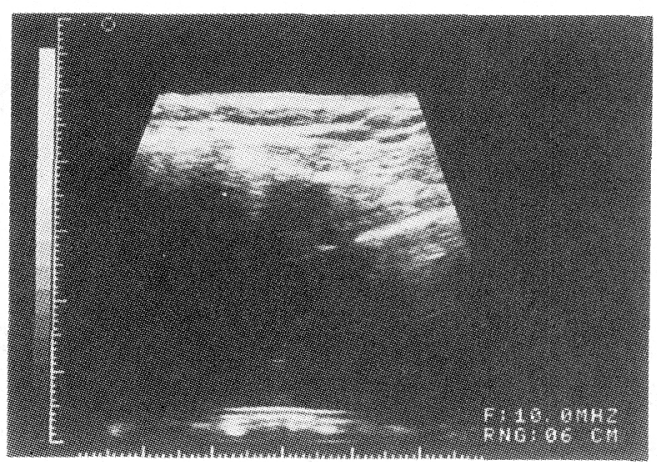

症 例 3
超音波画像でリンパ節の腫大は、まず内胸 陰性域の紡鍾状開大として表れ、限局性のエ コー像として形成される。リンパ節は $10 \mathrm{~mm} に$ 腫大すればまず検出可能で限局性低エコー像 となり描出される。6〜 $7 \mathrm{~mm}$ 大では紡錘状開 大となって検出される場合が多いが、検出さ れないことあある。 $5 \mathrm{~mm}$ 大以下では、内胸陰 性域の変化は認められずしたがって、腫瘤は 描出されなかった。

\section{IV 考 察}

胸骨傍リンパ節は転移をうけても小豆大以 上には大きくなりにくいと従来いわれてきた が、稀には大結節となって膨移してくること も経験された。又、当院では乳癌の発見され た患者や、手術を行った患者に対しては、定 期的に胸骨傍検查を行いリンパ節転移の有無 を診断している。このような観点から、超音 波診断装置の改良とともに胸骨傍検査の重要 性は増大して行くあのと考えられる。

\section{V まとめ}

1) リンパ節が $10 \mathrm{~mm}$ 大に腫大すると限局性の 低エコー像として描出される。

2) リンパ節が $6 〜 9 \mathrm{~mm}$ 大では、腫瘤像が検 出される場合が多いが、検出されない場合 あある。

3）リンパ節が $5 \mathrm{~mm}$ 大以下では、内胸陰性域 の変化が認められず描出不良であった。

\section{参考文献}

1) 霞 富士雄：超音波最近の進歩 胸骨 傍リンパ節検査 1985 


\section{$1 \mathrm{~J} 13$ 子宮癌検診の問題点}

秋田県厚生連山本組合総合病院

産婦人科 ○高橋 裕、佐藤宏和、真田広行

臨床検査科 西方照二、斎藤孝良、伊藤朝夫

はじめに

子宮癌検診は広く一般化し、子宮癌の早期 発見に重要な役割を果たしてきた。今回は、 当院で行っている子宮癌検診の実施状況と、 当院で治療した子宮顠癌患者を調查し、子宮 頙癌が発見されたきっかけ、検診の抱える問 題点などについて検討したので報告する。

調查期間および対象

調查期間は昭和 62 年度から平成 4 年度まで の6 年間とした。同期間中に、当院で実施し た検診バスによる集団検診受診者は5215人、 院内人間ドック受診者は13553人、婦人科外来 における施設検診受診者は8549人であった。

また、同期間中に発見され、当院で初回治 療を受けた子宮頸癌患者は58例であった。

結 果

(1)検診バスによる集団検診

町村における集団検診受診者の年齢分布を 見ると、ピークは55-59才で、50才代と60才代 で全体の56.2\%を占めている。20才代と70才以 上では、全体の2.9\%に過ぎなかった。菓団㛟 診で発見された頸癌患者 4 人（発見率;

$0.077 \%$ )のうち、3 人は60才以上の受診者で あり、町村における集団㛟診では、主に高龄 者の頚癌患者が発見されている。

(2)人間ドックにおける子宮癌検診

受診者の年龆分布を見ると、ピークは5559才で50才代と60才代で全体の55.4\%を占めて いる。一方、20才代と70才以上の受診者は合 わせてみてもわすかに $1.1 \% に$ 過ぎなかった。

人間ドックで発見された頸癌患者は 6 年間
で5人あったが (発見率；0.037\%)、これら 5 人全員とも年齢が 30 才代の比較的若い人達 であった。これは、バスによる菓団検診で発 見される频癌患者が高齡者であることと対照 的である。

(3)婦人科外来における施設検診

外来においては、子宮癌検診を目的に受診 する患者の他にも、未受診者には子宮癌検診 を受診するように勧めている。特に最近では、 若い年代の子宮頸癌患者も目立つことから、 妊婦にも検診の必要性を話し実施している。 このように、婦人科を受診したついでに我々 医師の勧めにより子宮癌検診を受ける、いわ ゆる「ついで娭診」の数は年々增加している。 (4)子宮䫫癌患者の内訳

58例中の内訳注CIS 32例、I a 期 6例、I b 期 3例、I b期 (OCC) 2例、II 期 4例、III期 7例、 IV 期 4例であった。年代别にみると、図 1 に 示したように30才代で発見される症例が最も， 多く、以降40才代、50才代と高龄になるにし たがって形癌患者の数は減少していく。

つきに、各年代における頸癌患者の榎床進行 期の内訳を図 2 に示した。CISの占める割合は、 20才代で $100 \%$ ，30才代で78\%、40才代で $62 \%$ ， 50才代で50\%、60才代で29\%、70才代で20\%、 80才代で0\%であった。

図3に菓団検診群、人間ドック群、施設 検診群、「ついで㛟診」群、有症状受診群に おける臨床進行期の内訳を示した。CISの占め る割合は、集団検診群 $81.8 \%$ 、人間ドック群 $80.0 \%$ 、施設検診群 $77.8 \%$ 、「ついで㛟診」群 
87.5\%、有症状受診群5.3\%であった。さらに、 症状が出てから受診した症例の89.5\%は浸閏癌 の状態で発見されており、しかも、その半数 以上の11例 (57.9\%) は発見された時点ですでに 手術の適応外であった。

(5)子宮頸癌発見のきっかけ

表 1 に58人の頸癌患者がどの様なきっかけ で子宮癌検診を受けたかを示した。このうち の38人が無症状の状態で頸癌と診断されたが、 そのきっかけは、集団検診（バス検診）、人 間ドック、施設検診、「ついで検診」の順に、 $28.9 \% 、 26.3 \%, 23.7 \%, 21.1 \%$ であった。

\section{考 察}

発見された子宮頸癌の89.4\%は初回検診時に 発見され、過去に検診歴のあるものは、わず かに10.6\%であると東岩井は報告しているが、 今回の我々の調査でも、集団検診で発見され た䫫癌患者のほとんどが、集団検診を本格的 に行った当初に発見されており、それ以降は
影をひそめている。以上の事から、検診受診 者の固定化現象が示唆される。

70才を越えると、検診の受診率が著しく低 下し、症状が出てから病院を訪れる事になる。 その結果、図 2 に示したように、70才代、80 才代と年龄が進むにつれて、進行した症例の 占める割合が増す。高龄者では性器に対する 無関心などから受診が遅れるため、進行症例 が多いと考えられる。従って、高齢者の検診 受診率の低さが問題である。

性生活の若年化にともない、子宮頸癌の発 生も若年化の傾向をたどっている。当院で扱 った症例の中にも20才代の患者が 3 人 (5.2\%) 含まれており、前述の傾向を物語っている。 また、30才代の患者18人の中に 4 例(22.2\%)の 微小浸閏癌と浸潤癌が含まれていた。これら を考え合わせると、30才を過ぎてから検診を 受けていたのでは遅すぎると考えられた。

\section{（図1）各年代別臨床進行期}

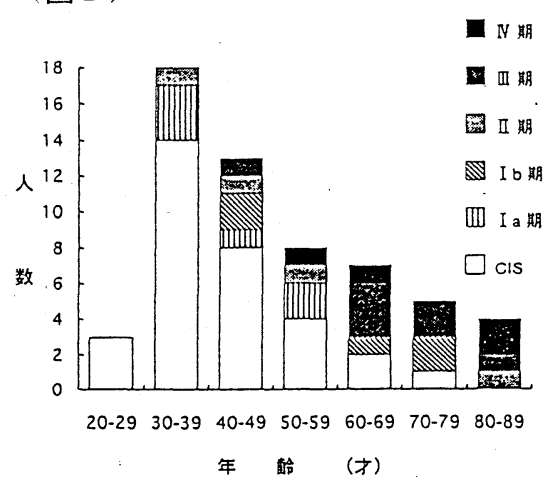

（図３）各群における躁床進行期の内訳

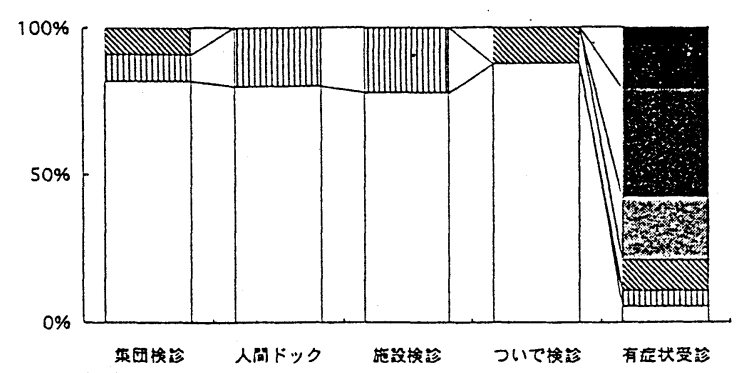

（図2）各年代における臨床進行期の内訳

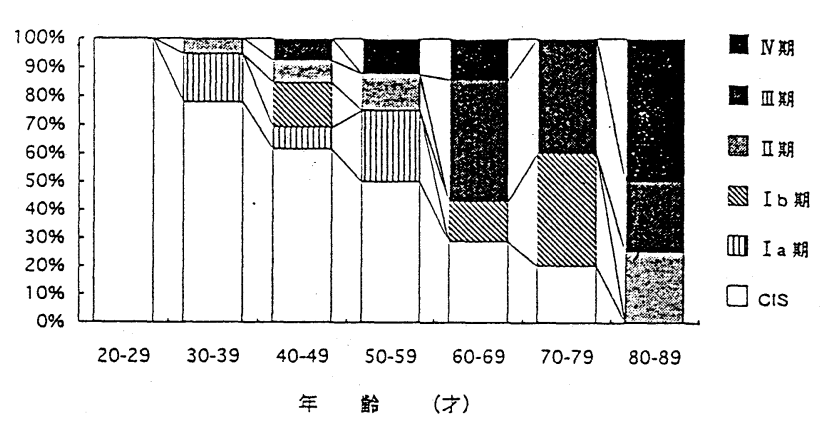

（表1）子宮癌検診のきっかけ

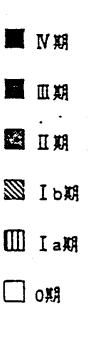




\section{$1 \mathrm{~J} 14$ 当院における子宮頸部早期がん治療内容の検討}

潤田嘉朗、中川国四、一宮和夫、依光毅、 丸山善德、別府正志

土浦協同病院産婦人科

[はじめに】早期がん治療の問題点はその 術前診断精度が先づ問題となる。当施設での 細胞診、コルポ狙い組織診のがん診断一致率 は、 0 期が $30 \%$ 、I a 期が $53.8 \%$ 、Ib 期 $84.2 \%$ で特に早期がん診断のむづかしさを第 41 回日 本農村学会総会で報告した。この精度下に抽 ける治療内容はいかにあるべきか、自験例と 文献的考察とから検討してみた。特に診断的 有用性と診断的価値の高い円錐切除術診断 0 期のとき、子宮摘出の問題点を患者のQ O L の観点とからわれわれの見解も示した。

[対象] 昭和 62 年より平成 2 年までに当院 飞初回入院治療した子宮頸部扁平上皮がん

153 症例中の 0 期 46 例、I a 期 43 例の手術例 である。このうち円錐切除 (以下円切) 後確定診 断し得たものは33例である(このうち2例は子 宮摘出世ず)。年令分布はいづれも圧倒的に 30 才代 ( 0 期 $50 \%$ 、Ia 期 $39.7 \%$ ) と40才代 ( 0 期 33\%、 Ia期 $34.9 \%$ ）とに多かった。

\section{[成績]}

\section{0 期の治療内容}

日本産科婦人科学会腫瘍委員会 (以下委員会) 138 医療機関の 1.916 例 (昭和61年度) と当院の 少数例と対比してみると、単純子宮全摘出術 (以下単摘) が委員会で $62.4 \%$ 、当院は $84.8 \%$ となっている。最近患者のQOLを考慮して 治療的円切のみで follow upする施設が増加す る傾向にあるが、委員会は $12.2 \%$ 、当院は $4.3 \%$ と少なかった。また準広汎子宮全摘出術(以下 準広汎）。委員会 $14.8 \%$ 、当院 $10.9 \%$ となって いるが、われわれの施設では 0 期の術前診断
精度に不安があったため施行したもので、正 当な術式とは考えたくない。委員会の施設で も同じような理由であったかどうかか不明で ある。

\section{Ia期の治療内容}

委員会の内容と大きな差を認めたのは、当 院では広沉子宮全摘出術 (以下広沉が $51.3 \%$ と 約半数であり、委員会は $8.5 \%$ と極めて少な かった。委員会では[準広沉]+[準広沉+リン八節廓清] が55.5\% と約半数であり、当院では $39.5 \%$ と なっていた。委員会では単摘が $27.2 \%$ 、円切 が $3.6 \%$ となっている点について、われわれ としてはIa期術式として過小術式であるとい ら立場をとりたい。当院での単摘 $9.3 \%$ (4例) は円切を省いたための過小手術と理解してい る。当院の Ia期 43 例中のリンパ節廓着した 39 例の転移症例はなかった。また術後 5 年経過 してないものもあるが、再発例は今の所 1 例 もみとめてない。

\section{3. 円錐切除診断 0 期の問題点}

円切診断 0 期 22 例、I I 期 9 例の計 31 例飞つ いて円切のSurgical margineの”がん゙有無 と摘出子宮の違残がんの有無を検索してみた。 Surgieal marginの”がん゙positiveは別として negatiueで摘出子宮の頸管部に違残がんをみ とめたのは 3 例( $12 \%$ )で、いづれも円切 0 期 で違残がんも in situであった。この 3 例を 臨床病理学的飞検索すると、いづれも円切病 巣部 $(\mathrm{S}-\mathrm{C}-\mathrm{junction}$ 凡沿って存在している) と 分離して非連続的に多発がん的に子宮頸管部 の一部に病巣が存在していた。 
これは治療的円切のfollow upとその後の再 発との関連にかかわる重要な問題と思われる。 [考察]

根治術式の問題を考える場合、正確な術前 診断が前提条件となるのであるが、0 期の術 式は委員会でも様々であることは、術前診断が 施設によって正確さを欠いていた証左かもしれ ない。高率の術式がその臨床期の最適の術式 であると短絡的に決められるものではないが、 逆に多くの専門がん治療機関による高率の術 式は現状の診断精度下に抢ける適した術式で あろうと推定してよいかも知れない。いづれ にしても各臨床期による過小もなく過剩もな い根治性のある最適の術式之は、長期予後に よって判断されるものであろら。0 期の根治 術式は多くの報告者と同じく単摘が最適であ り、円切のみはまだ疑問点が残るものとした い。

Ia期の術式は広汎が $51.2 \%$ とわれわれの施 設ではきわめて多かったが、これは術前診断 の正確さに不安をもったために選択したもの と思われる。全例、現在まで再発例もなくり ンパ節転移例もなかったことより、Ia 期の根 治術式は準広汎あるいは[準広汎+リンパ節廓清] が最適としたい。勿論、われわれのIa期症例 で円切診断 Ia で 単摘診断 no cancer 症例 も 経験しているが、Ia期症例がすべてこのよう な症例でないことは言らまでもない。今後正 確な術前診断飞自身をもてるような診断方法 があれば、あるいは単摘でも、また円切のみ でも充分であるといえるよらになるか子知れ ないが、文献的にはIa期の単摘例には、断端 再発例が $1.3 \%$ と報告されていることも念頭 そいれねばならないであろら。

次飞臨床病理学的検索で 0 期病巣の胵部扔 よび頸管部の広がりの多彩性、単発あるいは
多発性、連続性あるいは非連続性等の問題点 が、円切 0 期診断飞存在していたことをわれ われは報告したが、われわれの報告は少数例 (25 例)中の 3 例 $(12 \%)$ であり、このような病 巣の広がり型の 0 期症例がどれほどあるのか、 もっと多数例の中から検討されねばならない であろら。

また、このよらな円切 0 期を治療的円切の みで follow upするためには、頸管内に病巣を 取り残さないための円切術の術式に対する検 討が必要となろら。それには術前に子宮頸管 部の内子宮口以上飞達する長さを推定してお き、出来る限り円錐の高さを長く切除するこ とと、術時あるいは術前飞頸管内掻爬の細胞 診および組織診を試みるべきであろら。近年 レーザー療法か蕔告され、蒸散法と円錐切除法が あり、それぞれの適応と条件が存在している が、基本的には上記注意事項は同じものと思 われる

\section{[まとめ]}

1. 子宮頸部早期がん治療の問題点は出来 る限り診断精度を確実にすることである。

2. 0 期の根治術式は単摘が最適であると 思われた。しかし患者のQOL 等の問題から 単摘しないのであれば、厳重に外来での follow upを、しかも長期にわたることを患者にイン ホームコンセントすべきである。

3. Ia 期の術式は縮小術式の可能性が示唆 されたが、準広沉が最適であると思われた。

4. 円切 0 期は患者の年跲 - 妊孕性の問題 を考慮すべきであるが、現状の診断精度下で は子宮摘出した方が無難と思われた。 


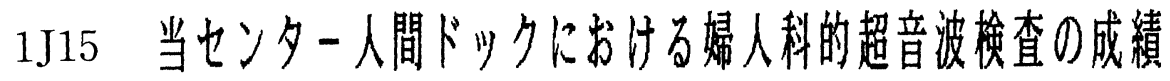

○袁 鳴芳、落合まさ子、在原文夫、依田芳起、今福圭子 平田修司、花形悦秀、宮沢泰彦、小林一久

（山梨県厚生連健康管理センター）

\section{[はじめに]}

当センターでは1988年から人間ドックの女 性受診者全員に下腹部の超音波唡查を施行し てきた。今回、我々は最近 5 年間の婦人科工 コー唡查について検討したので報告する。

\section{[対象と方法]}

1988年 4 月から1993年 3 月までの人間ドッ クの女性受診者 14,050 名を対象とした。装置 はアロカSSD650、アロカSSD680を使用し、娭 查は主として臨床検查技師が担当し、上腹部 の超音波娭査を行った後、膀胱充満状態で子 宮、卵巣等の婦人科的超音波検查を行った。 拾いあげられた所見の判定は当センターの医 師が行い、要精検者は精検医療機関に紹介し、 その返信結果を集計処理して検討した。

\section{[結果]}

表 1 に年度別受診者数を示したが、年々継 続受診者の割合が增加しており、最近では60 \%を越えている。

年令別受診者数を図 1 に示したが、50才代 が最も多く34.4\%を占め、以下40才代(32.0\%)、 60才代(25.0\%)の順であった。

婦人科エコー娭査の結果を表 2 に示したが、 14,050名のうちエコ一検査で異常がなかった 者は 13,063 名(93.0\%)で、有所見者は984名 (7.0\%)でそのうち要精査者は462名(3.3\%)で あった。

要精唡所見の内訳を図 2 に示したが、子宮 睡煌(含疑い)が一番多く63.6\%であった。次 は卵巣整腫(含疑い)で $14.1 \%$ 、次は子宮内部 エコー不均一で $8.2 \%$ 、次は卵巣腫瘍(含疑い) で8.0\%であった。

462名の要精検者の中、医療施設から返信が あったのは 229 名(49.6\%)で、そのうち異常な しだった37名を除く192名(83.8\%)は何らかの
異常を有しており、子宮筋腫が136例、卵巣俥 腫が41例、卵巣癌が 1 例発見されている(表 3 )。 卵栄癌症例は41才で術前の生化学検査やCA19 -9、CA125は正常であった。手術所見は stage I cで転移なし、組繶学的にはclear cell adenocarcinoma であった。本症例は前年も当 センターの検診を受けているが、その時は異 常を指摘されていなかつた。表 4 に診断後の 処置をまとめて示したが、手術を受けた者が 18名(9.4\%)あり、そのうちの 1 例が卵单癌 で他は卵巣腫が 8 例、子宮筋腫 8 例、子宮 内膜症 1 例であった。

\section{[まとめ]}

1. 1988年〜 1993年の 5 年間の人間ドックで 女性 14,050 名に婦人科的超音波検査を行った。 受診者は 50 才代(34.4\%)が最も多く、以下 40 才代 $(32.0 \%) 、 60$ 才代 $(25.0 \%)$ の順であった。 2 . 受診者中エコー㮩査で異常なしが93.0\%

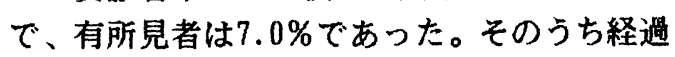

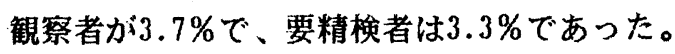
3.要精娭者のエコ一所見は、子宮腫湯 (含疑 い)が $63.3 \%$ 、卵巣索腫が $14.1 \%$ 、子宮内部工 コ一不均一が8. $2 \%$ 、卵巣腫湯(含疑い)が8.0 \%、その他が $6.1 \%$ を占めた。

4. 要精検者のエコ一検査結果と医療施設の 診断結果とを比較すると、子宮腫湯(含疑い)、 㽗巣囊腫(含疑い)の一致率はそれぞれ78.8\%、 74.2\%であった。

5 . 卵巣癌が 1 例発見されたが、その症例は 自覚症状はなく、生化学娭査や腫湯マーカー 等全て異常なく、エコー娭診のみで早期に発 見された症例で、今後もこのような早期段階 の婦入科癌が発見できるよう努力していきた い。 
表 1 年度別女性人間ドックエコー受診者数

\begin{tabular}{|c|c|c|c|}
\hline 年度 & 総受彭者 & 初回受診者 & 継続受診者 \\
\hline 1988 & 2148 & 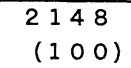 & 0 \\
\hline 1989 & 2460 & $\begin{array}{c}1525 \\
(62.0)\end{array}$ & $\begin{array}{c}935 \\
(38.0)\end{array}$ \\
\hline 1990 & 2923 & 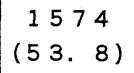 & $\begin{array}{c}1349 \\
(46.2)\end{array}$ \\
\hline 1991 & 3072 &  & $\begin{array}{c}1910 \\
(62.2)\end{array}$ \\
\hline 1992 & 3447 & $\left.\begin{array}{cccc}1 & 3 & 1 & 5 \\
(3 & 8 & & 2\end{array}\right)$ & 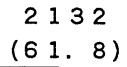 \\
\hline 計 & 14050 & $\begin{array}{c}7724 \\
(55.0)\end{array}$ & $\begin{array}{r}6326 \\
(45.0) \\
\end{array}$ \\
\hline
\end{tabular}

表2人間ドック婦人科エコー検查の結果

\begin{tabular}{|c|c|c|}
\hline 判 & 人 & 数（\%) \\
\hline 異常なし & 13,063 & $(93.0)$ \\
\hline 経 過観 察 & 525 & $(3.7)$ \\
\hline 要精密検查 & 462 & (3. 3) \\
\hline 合 & 14,050 & $\left(\begin{array}{lll}1 & 0 & 0\end{array}\right)$ \\
\hline
\end{tabular}

表了要精椣者の换查結果

\begin{tabular}{|c|c|c|c|c|c|c|}
\hline $\begin{array}{c}\text { 要精模 } \\
\text { 所胃 } \\
\text { 精果 } \\
\end{array}$ & 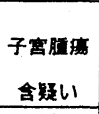 & 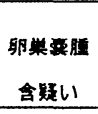 & 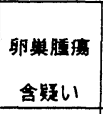 & $\begin{array}{l}\text { 子容内部 } \\
\text { I工一不均一 }\end{array}$ & その他 & 合 計 \\
\hline 異常なし & $\begin{array}{c}24 \\
(15.5) \\
\end{array}$ & $\begin{array}{c}5 \\
(16.1) \\
\end{array}$ & $\begin{array}{c}3 \\
(23.1) \\
\end{array}$ & & $\begin{array}{c}5 \\
(25.0) \\
\end{array}$ & $\begin{array}{c}37 \\
(16.2) \\
\end{array}$ \\
\hline 子害筋譄 & $\begin{array}{c}126 \\
(78.8) \\
\end{array}$ & & $\begin{array}{c}2 \\
(15.4) \\
\end{array}$ & $\begin{array}{c}2 \\
(40.0) \\
\end{array}$ & $\begin{array}{c}6 \\
(30.0) \\
\end{array}$ & $\begin{array}{c}136 \\
(59.4) \\
\end{array}$ \\
\hline  & $\begin{array}{c}5 \\
(3.1) \\
\end{array}$ & $\begin{array}{c}23 \\
(74.2) \\
\end{array}$ & $\begin{array}{c}6 \\
(46.2) \\
\end{array}$ & $\begin{array}{c}1 \\
(20.0) \\
\end{array}$ & $\begin{array}{c}6 \\
(30.0) \\
\end{array}$ & $\begin{array}{c}41 \\
\text { (17.9) } \\
\end{array}$ \\
\hline 卵 童 庶 & & & $\begin{array}{c}1 \\
(7.7) \\
\end{array}$ & & & $\begin{array}{c}1 \\
(0.4) \\
\end{array}$ \\
\hline 子宫脜大 & $\begin{array}{c}3 \\
(1.9) \\
\end{array}$ & $\begin{array}{c}1 \\
(3.2) \\
\end{array}$ & & & & $\begin{array}{c}4 \\
(1.7) \\
\end{array}$ \\
\hline 子富内膜症 & & & $\begin{array}{c}1 \\
(7.7) \\
\end{array}$ & $\begin{array}{c}1 \\
(20.0)\end{array}$ & & $\begin{array}{c}2 \\
(0.9) \\
\end{array}$ \\
\hline その 他 & $\begin{array}{c}2 \\
(1.2) \\
\end{array}$ & $\begin{array}{c}2 \\
(6.5) \\
\end{array}$ & & $\begin{array}{c}1 \\
(20.0) \\
\end{array}$ & $\begin{array}{c}3 \\
(15.0) \\
\end{array}$ & $\begin{array}{c}8 \\
(3.5) \\
\end{array}$ \\
\hline 合 & 160 & 31 & 13 & 5 & 20 & $\begin{array}{c}229 \\
(100)\end{array}$ \\
\hline
\end{tabular}

图 1 人間ドックエコー年令別総受紾者の頻度

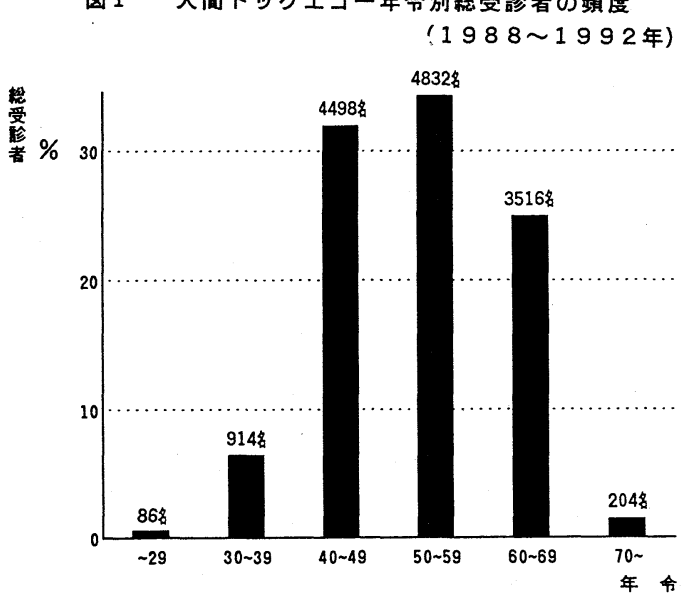

图 2 要精㛟者のエコ一所見別割合

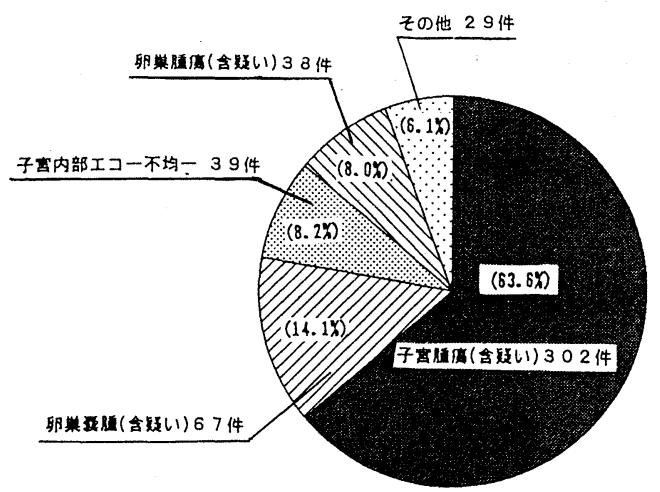

表4診断後の処置

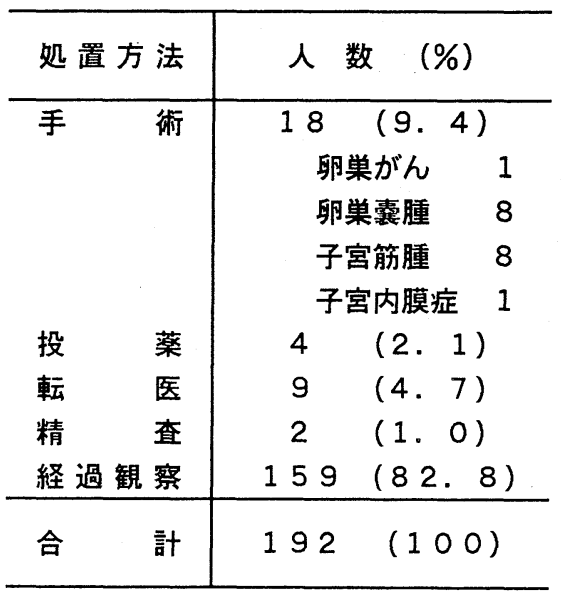


産婦人科におけるMRI診断の検討

神奈川県厚生連 伊勢原協同病院 産婦人科

○星合敏久 北川寛八幡剛喜 王正貫 櫛淵大策

Magnetic Resonance Imaging (M R I ) は、子宮腫瘍や卵巣腫瘍 の診断に有用であることが明らかにされつつある。

M R I は一般に、1. 組織・臓器間のコントラストが良い、2. 断層面の選択性がある（横断面、矢状断面、前額断面など）、3. 生殖器への影響がない（X線被爆がない）、4.非侵襲である（人 体に傷をつけない）、などの長所を持つ。

当院においても本年 4 月から M R I を導入しているが、これらの 疾患の診断に効果をあげている。今回、当科における M R I 診断の 精度について検討を行ったので報告する。対象は 4 月より 6 月末ま でにMR I を施行した 55 症例とした。

M R I 装置は、横川メディカル M Rベクトラ F a s t を使用し、 spin echo 法にて T 1 強調画像（T 1 像）と T 2 強調画像（T 2 像） を撮像して検討した。

まず、卵巣腫瘍において、腫瘍内容液intensity は子宮内膜症性 囊胞および皮様囊胞腫では T 1 像、 T 2 像ともにhighで特異的であ ったが、その他の腫瘍では内容液の性状にかかわらず T 1 像で 10 、 T 2 像でhighとなる傾向を示した（例えば、漿液性囊胞腺腫など）。

次に子宮腫瘍では、子宮筋腫と子宮腺筋症につき検討したが、筋 腫核は T 2 像でlow intensityに描出され周囲の筋層との境界が明 瞭な腫瘍として認識された。又、子宮全体は凹凸辺縁不整であるも のが多かった。

一方、子宮腺筋症では T 2 像において子宮腺筋症病巣と正常子宮 筋層との間には、大きなintensity の差がないため両者を識別する ことはできず、high intensityに描出される子宮内膜と、腫大した 
子宮筋層との関係により病巣の存在が推定された。又、辺縁は整で 腫大した子宮として描出された。

以上、当科における主な疾患の M R I 画像の検討を行い報告した が、診断に関しては C T、超音波などの他の画像も総合することに より、より正確なものになるものと思われる。今後症例を重ね、更 に詳細な検討を続けて行きたい。

なお、以下に典型的な画像を揭載する。

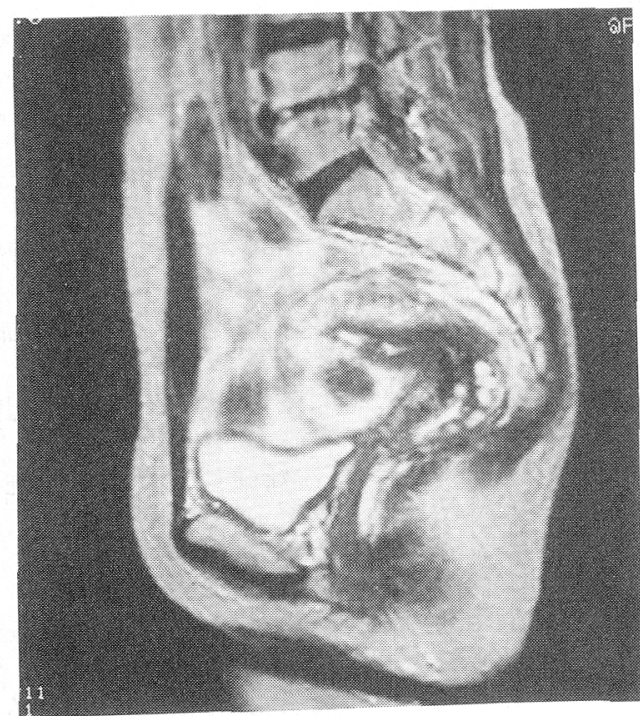

図. 子宮筋腫 ( T 2 像)

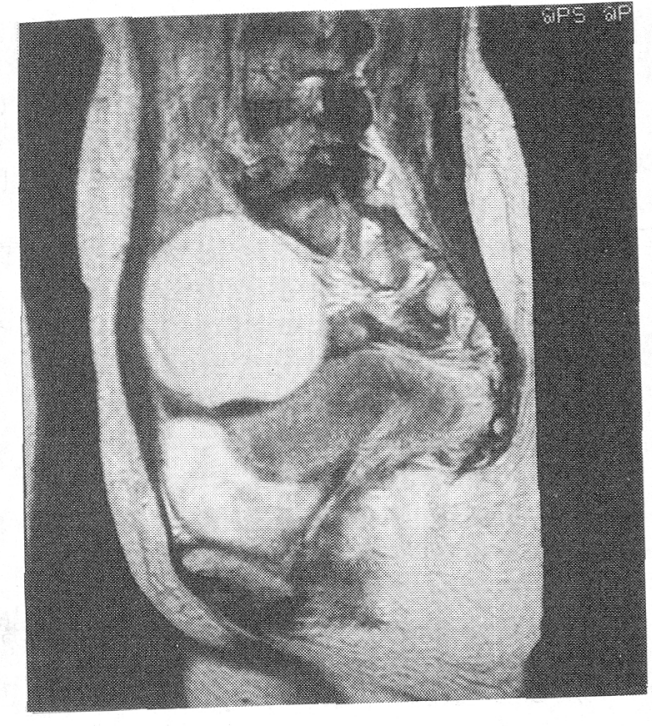

図. 子宮内膜症性囊胞 ( $\mathrm{T} 1$ 像) 
○樋口正臣・松信晶・大山正俊・望月愛郎・ 三宅崇雄・秦和子 ·梶野徹・佐藤芳昭・大沢章吾 (相模原協同病院産婦人科) 小原喜代志・小柴礼子（同検査室）

\begin{abstract}
緒言
B 群溶連菌（g r o u p B - h e m o l $y$ t i c streptococcus, G B S ）は胵の常在菌であるが近年、新生児の 重篤な垂直感染症の起炎菌として注目され、 本邦における G B S 感染症の報告の増加と共 にその発症予防に対する関心が高まっている 1 ，2，3）。そこで我々は過去 5 年間に当 科を受診した妊婦を対象にしGBSの保菌状 況を検索し併せて新生児に対する影響につい て検討をおこなった。
\end{abstract}

\section{研究方法及び成績}

当科を受診した妊婦の胵分泌液、肚門擦過 液及び分婏時の羊水、新生児の口腔内液、耳 擦過液を研究対象とした。GBS の検索方法 は、これらの分泌液を血液寒天培地により $G$ B S の分離培養を行い增菌数が少なければ増 菌培養を行い、その後、溶血レンサ球菌群別 及び型別用免度血清（デンカ生研）により菌 の同定を行った。その結果、妊婦 3,790 例中 541 例（14.3\%）が陽性であり菌型 としては不明群を除き I a 型、III型がそれぞ れ $18.2 \% ， 20.6 \%$ と高值を示した（表 1)。 また G B S 陽性妊婦の肛門擦過液、分娩時の
羊水、新生児の口腔内液、耳擦過液の G B S の陽性率はそれぞれ $33.5 \%, 36.6 \%$ ，3 $2.5 \% ， 34.5 \%$ とほぼ1／3の陽性率を認 めた（表 2）。更に、これらのGB S 陽性妊 婦から出生した新生児のすべてに特に新生児 感染症は認められなかった。

\section{ま と め}

1) 妊婦の約 $14 \%$ G B S が認められた。

2) G B S 陽性妊婦の塍、羊水、新生児の口 腔及び耳に約 $35 \%$ G B S が検出された。

3） G B S 陽性妊婦より出生した児の全例に は特に感染症は認められなかった。

以上より GB S は膣内常在菌であり G B S 保 菌妊婦に対する予防的化学療法の必要性はな いと考えられた。

\section{文献}

1. BakerC. J. : Summary of the workshop on perina ta 1 infections due to group B streptococcus. J. infect.dis., 13 $6: 137,1977$. 
2. B o y e r, K. M., Gotof $f$, S. P. : Prevention of ear$1 \mathrm{y}-\mathrm{onset} n$ e onat a $\mathrm{lg} \mathrm{r-}$ oup B st reptococca

d isease with select i$\mathrm{ve}$ int rapartum chemop r o phy l axis. N. Eng.J. Med., $314: 1665,1986$.
3. 後藤節子、杉山正子： $B$ 群溶連菌 ( G B S ) 感染症の垂直感染とその予防. 産婦 人科治療, $57(6)$ ：681, 1988 .

表 1 妊婦の G B S 保菌状況と菌型

\begin{tabular}{|c|c|c|c|c|c|c|c|c|c|}
\hline \multirow{2}{*}{ 年＼cjkstart度 } & \multirow{2}{*}{ 総 数 } & \multirow{2}{*}{ 陽性数 } & \multirow{2}{*}{$\begin{array}{c}\text { 陽性率 } \\
(\%)\end{array}$} & \multicolumn{6}{|c|}{ 菌 型 $(\%)$} \\
\hline & & & & I a & I b & II & III & IV & 不明 \\
\hline 1988 & 448 & 38 & 8.5 & 18.4 & 7.9 & 34.2 & 26.3 & 0 & 13.2 \\
\hline 1989 & 915 & 107 & 11.7 & 16.8 & 8.4 & 19.6 & 21.5 & 2.8 & 30.8 \\
\hline 1990 & 782 & 136 & 17.4 & 16.2 & 13.2 & 5.1 & 16.2 & 1.5 & 47.8 \\
\hline $\begin{array}{llll}1 & 9 & 9 & 1\end{array}$ & 616 & 105 & 17.0 & 15.3 & 11.7 & 3.6 & 21.2 & 4.3 & 43.9 \\
\hline 1992 & 647 & 103 & 15.9 & 18.8 & 6.8 & 3.4 & 17.1 & 2.6 & 51.3 \\
\hline 1993 & 382 & 52 & 13.6 & 23.4 & 6.4 & 2.1 & 21.3 & 4.3 & 42.5 \\
\hline 計 & 3,790 & 541 & 14.3 & 18.2 & 9.1 & 11.3 & 20.6 & 2.6 & 38.2 \\
\hline
\end{tabular}

表 2 G B S 陽性妊婦の羊水及び 出生時の口腔, 耳内のGB S

陽性率（\%)

\begin{tabular}{|l|l|l|l|l|}
\hline 総 数 & 肛 門 & 羊 水 & 口 腔 & \multicolumn{1}{|l|}{ 耳 } \\
\hline 541 & 33.5 & 36.6 & 32.5 & 34.5 \\
\hline
\end{tabular}




\section{I 、はじめに}

近年、米国においては、帝王切開（以下帝 切）率の上昇が社会的問題となり、それまで の反復帝切の概念 (Once a cesarean section, always a cesarean section) にかわるも のとして、VBAC (Vaginal Birth After Cesarean section) が推奖されるようにな た。本邦においても出生前診断学の進歩や、晚 婚化、少産化之いった社会的要因により帝切 分婏例は增えてきている。

今回私たちは、当院における過去 10 年間の 分婏例を調查し、前回帝切例の次回分婏様式 について検討を加えてみた。

\section{II. 結果}

当院における過去 10 年間の総分娩数は、3, 266件であった。分娩数は年々減少しているが、 帝切症例は増加し、帝切率は年々増加傾向を 示している。平均帝切率は、 $11.2 \%$ であるが、 最近では $15 \%$ を越える值を示している。（図 1、2）全帝切数は359例であり、その適応は、 CPD が $40 \%$ と一番多く、胎児切迫仮死、骨盤 位の順となっている。「その他」70例のうち、 いわゆる反復帝切が、42 例と大部分を占めて おり、全体の $11.7 \%$ であった。（表 1）

1 回の帝切を既往として持つ 120 例につき今 回の分婏様式を検討した結果、Elective CS （選択的帝切）を施行したものが84例（70\%) であり、Trial of labor (試験分婏、以下Trial) を行ったものが、36例（30％）であった。こ のうち VBACに成功したものは、34例であり、
○平 浩 之、吉 尾 豪

(愛知愛北病院)
分婏が遷延し CPD 疑にて緊急帝切となったも のは2例あった。(図3)

120 例の前回の帝切の適応は、CPD が $50 \%$ 骨盤位 $15.8 \%$ 、胎盤異常 $9.2 \%$ 、切迫仮死 5 . $8 \%$ \%゙であった。（図4）

Elective CSとなった84例の適応は、CPD50 \%、骨盤位 $11.9 \%$ 、筋腫合併 $3.6 \%$ な゙であ る。その他が $30 \%$ ちからるのは、社会的要 因を始め、種々の因子が関連しているものと 思われる。（図5）

また、前回帝切の適応別に、VBACの成功 率を見ると、前回CPDであったものが最も低 く、骨盤位、胎盤異常、胎児切迫仮死などで は、成功率は高くなっている。（図6）

Trial 36例の陣痛発来様式亡分婏は（図7） に示すような経過であった。

既往帝切が当院か他院かによる VBAC 成功 率を比較したものを（図8）に示す。

\section{III. 考察}

文献的にみると、Trialは50〜60\%であり、 VBACの成功率は報告者によりそれぞれ異な る。当院では、Trial率は低いが、成功率では かなりよい結果を得ている。Trialを行うにあ たっては、当院では、（表2）に示す方針に基 づいて施行している。

今後種々の要因で帝切率は増加する可能性 もあるが、不必要な反復帝切を避け、できる だけTrialを行いVBACを成功させていくこ とが重要ではないかと考える。 

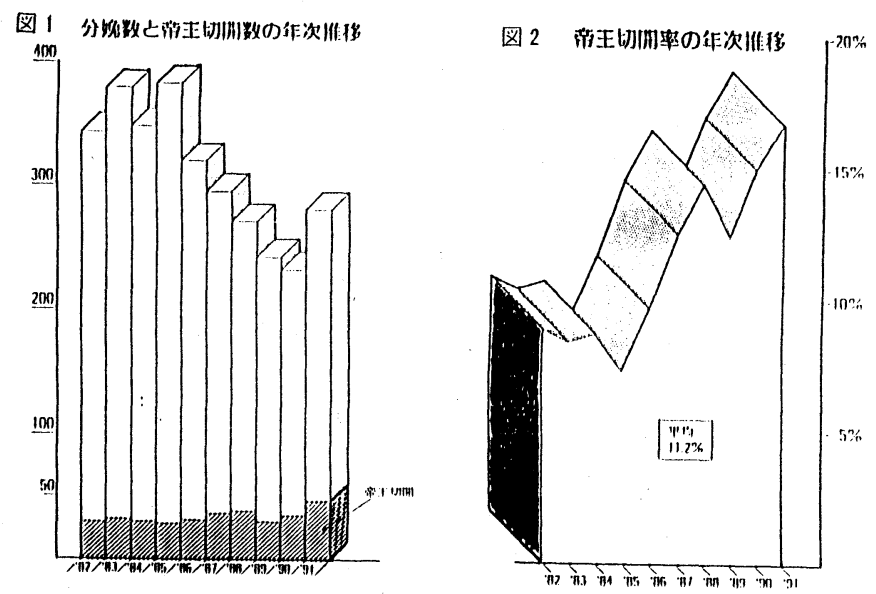

表 1 当院における帝王切開359例の適応

図 3

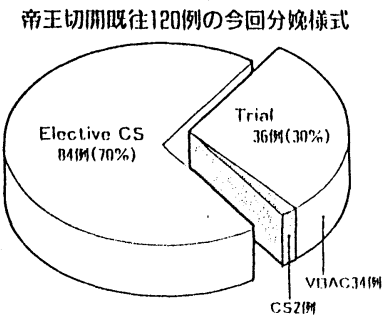

图 4 解回陑王切閉の適応

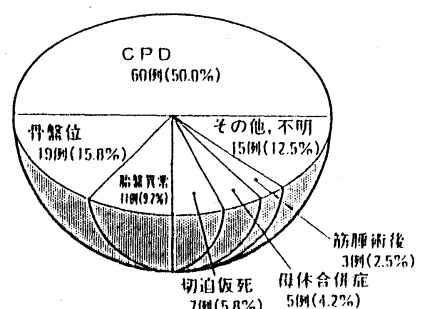

CPD 149 例 $(40.4 \%)$

胎児切迫仮死 $\quad 47$ 例 $\quad(13.1 \%)$

骨然位，撗位年 45 例 $(12.5 \%)$

胎船珙常 21 例 $(5.8 \%)$

节腫合佛 16 例 $(4.5 \%)$

回体合俳症年 5 例 $(4.2 \%)$

その他

70 例 $(19.5 \%)$
図 5
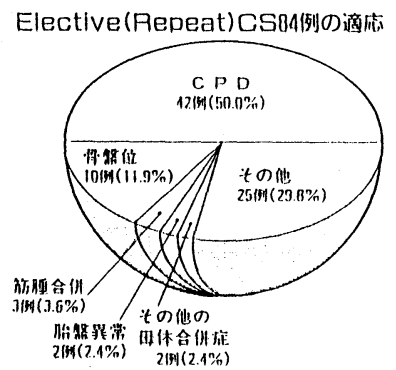

図 6

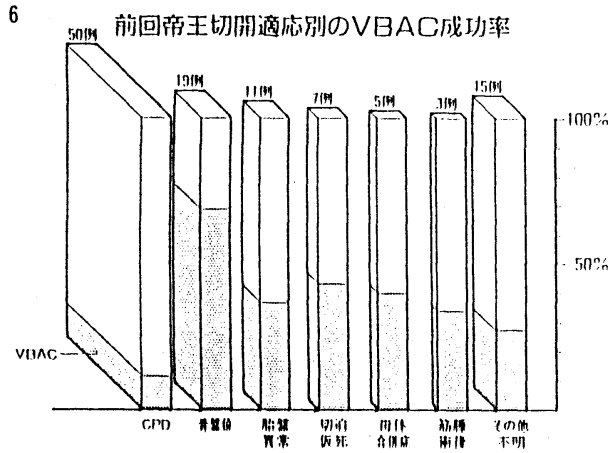

図 7

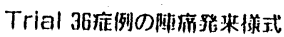

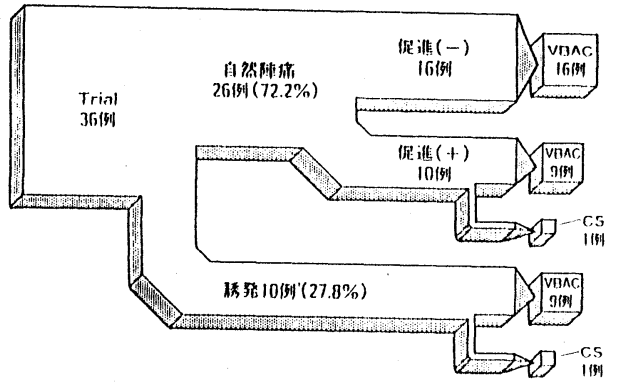

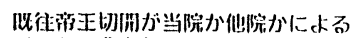
VBAC成功虽

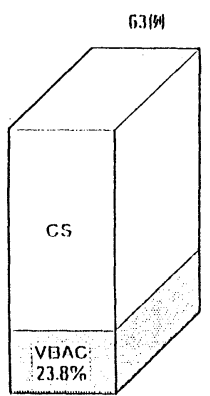

当 院



[他际]
表 2 Trialを行うにあたっての当科の方針

(1) 前回の谪応がCPDの場合は慎重に検討し，胎児・胎䑾因子の場合は原 则として可能とする。

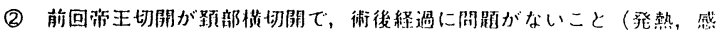
染徽候箱)。

(3)頭位であること。

(4) Bishop scoreが高いこと。


剂の使用は慎重におこなう。

(6) 2 回以上の帝切既往は除外する。

(1) Informed concent:゙ええられていること。

(B) Double set, upの体制にあること。 
神奈川県厚生連 伊勢原協同病院 産婦人科

○櫛淵大策 八幡剛喜 星合敏久 王正貫 北川寛

近年，急速に進行している中高年人口の增加は，産婦人科領域においても新しい視点での 医療が求められている。更年期前後の女性では, 卵巣性エストロゲンの低下・消失に伴っ て, 各種の不定愁訴が出現するが, とりわけ骨粗鬆症や心血管系疾患の増加を見逃すこと は出来ない。そこで, 予防的健康管理の一方法としてのホルモン補充療法（HRT）で あるが，欧米においてその有用性は広く認められ実地臨床で盛んに行われているが，本邦 でも最近やっと注目されつつあるといえよう。

当科では，本年 4 月から「中高年外来」を新設し，ホルモン補充療法（HRT）を中心 とした管理を行っているが，その実態について紹介し併せて $2 \sim 3 の$ 検討を試みたので報 告したい。

始めに，当科での「中高年外来」の診療手順を紹介する。

（1）初診時, 全ての患者に問診カード（表 1 ）と, 簡易更年期指数（表 2）を記入して もらう。（簡易更年期指数は毎回記入）

（2）スライドによる説明（更年期の生理・エストロゲン低下による生態（特に骨・脂質 代謝）への影響など）を行う。（約 10 分）

（3）各個人別に予診を取ったうえで，諸検查（表 3 ）を施行する。

（4）１～2 週後，治療を受けたい意思と，検查結果を確認した上でHR Tを開始する。 投薬方法を説明し，注意書き（表 4 ）を渡す。

検討事項：(本学会に於いて発表予定)

（1）「中高年外来」受診者の年令分布之意識調查

（2）HRTによる更年期症状の改善率（減少率）の分析

（3）HRTによる脂質代謝への影響（コレステロール・HDL・T G・ベータリポ蛋白 などの変化）

（4）骨塩量・骨密度の加令に伴う変化と，HRTによる影響。

（5）その他 


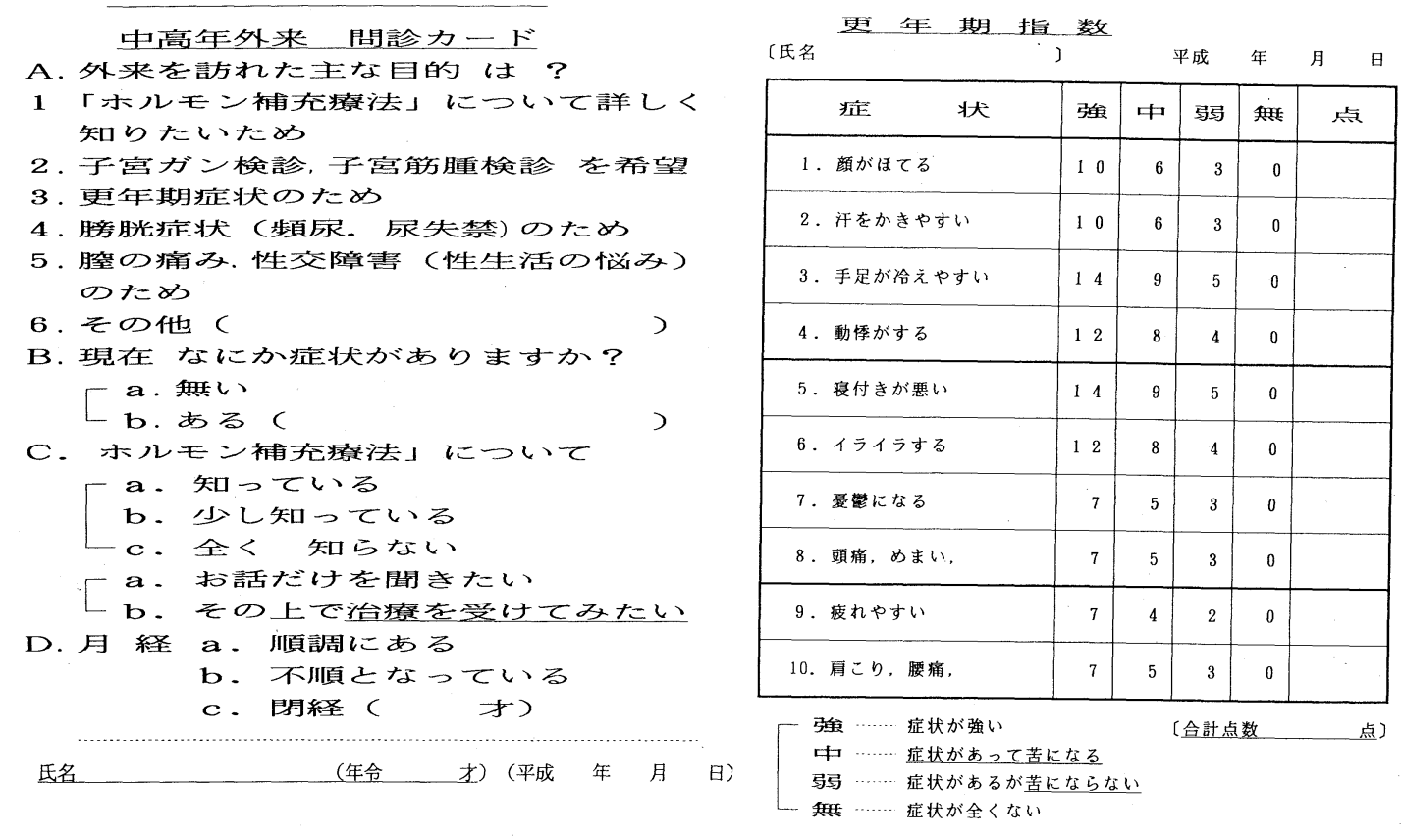

\section{〔検査項目〕}

表 31 . 一般的な身体所見（血圧．体重．更年期指数）

2. 検血一般

3. 血液生化学（GOT. GPT.コレステロール.

HDL．T G. ベータリポ蛋白）

4. 血中ホルモン (エストラジオール, F S H)

5. 骨量. 骨密度測定（MD／MS 法, Q C T )

6. 子宮癌検診 (莖部, 内膜の細胞診)

7. 乳房検診

「コルモン補㚐癔法」を栄けられる万人

表4 1. 薬は, 毎日忘れずに飲んで下さい。（飲み方は, 人により違いますので, きちん と, 指導を受けて下さい)

2. 検血, 子宮癌検診, 乳房検診は, 3 力月後におこない, その後は, 6 ケ月毎に 必ず検査を受けて下さい。

3. 薬を服用中に, 出血や乳房の張りがみられる事がありますが, ほとんど心配はあ りません。 但し，あまり続いたり，心配でしたら受診して下さい。

4.この療法は，65才位まで続けることがよく，むしろ 20 年位続けることが推奖 されています。一生続けてもかまいません。

5. ホルモン補充療法の禁忌としては, 肝機能障害患者. 血栓症のある人. 乳癌・子宮 癌. 心不全・腎疾患 のある人です。また，子宮筋腫・子宮内膜症患者・高血圧・ 糖尿病（インスリン使用）の人は，注意して行うことが必要です。

* ホルモン補充療法は, 閉経後の女性の生き方の質の向上を, 医療サイドから提言 する方法であって，決して強制するものではありません。長期の服用となります ので,よくお考えの上で害行に移して下さい。 


\section{J20 Dyssegmental dysplasiaの一例}

相模原協同病院 産婦人科 $\bigcirc$ 秦 和子、三宅崇雄、梶野 徹 樋口正臣、佐藤芳昭、大沢章吾

小児科 原 真人、藤野宣之、横田行史

\section{1.はじめに}

Dyssegmental dysplasia (Dd) は骨系統の異常を 示す胎児奇形であり、割合に珍らしく他の Weissenbacher 症候群などのようなShort-Limbed Lethal Neonatal Dwarfism などと鑑別を要し、胎内診断の報告も みるようになって来た。症例は28才の初産婦で骨盤位の ため骨盤計測 X 線を行ったところ下肢骨が不鮮明のため、 再度超音波で慎重に計測したとてろ四肢短縮をみとめ、 その後骨艋位で分婏したが、1 ケ月後に呼吸不全で死亡 し、剖検を行った一例についてその経過を報告する。

\section{2. 症例}

患者；M.S.28才 経妊0

既往歴; 家族歷、月経歷 ; 特記すべきてとなし 現病歴打よび入院経過; 平成 4 年 5 月 20 日を最終月経 として妊娠し、当科にて外来管理されていたが、その経 過は骨盤位であること以外は特別に問題なかった。

妊娠28週より堎胸位を行ったが頭位とならず妊娠34週 で、腹緊のため膝胸位を中止した。平成 5 年 3 月 1 日、 妊娠40週で Guthmann 骨盤計測を行ったところ下肢骨が 不鮮明であった。翌日、3月 2 日、陣発のため入院とな った。入院時所見は身長 $153 \mathrm{~cm} 、$ 体重 $63 \mathrm{~kg}$ 、子宮底 $33 \mathrm{~cm} 、$ 第 II 骨盤位で内子宮口は $4 \mathrm{~cm}$ 開大、展退率 $70 \% 、 \mathrm{Hb}$ 值 $11.4 \mathrm{~g} / \mathrm{dl}$ であった。

入院後 Guthmann 骨盤計測を再検し、超音波で大腿骨 長を精查したところ、四肢の短縮を認めた。プロスタグ ランジン $\mathrm{E}_{2}$ を経口投与後、アトニン 0 点滴静注により 分婏促進し、同日 $2,910 \mathrm{~g}$ Apgar Score $3 / 7$ 点の女 児を婏出した。

\section{3. 児の経過}

分婏直後気管内扱管し、小坚科入院となった。入院時、 新生児仮死及び外表上四肢短縮、胸部低形成、関節拘縮 を認めた。

日令 1 日、気管内捰管は抜去となり、日命 2 日よりミ ルクは経口と、tube feeding 併用となった。体重も増加 した。日令 3 日、心雑音を聴取し心房隔欠損を認めた。 このころよりミルクの飲みがわるくなった。日令 8 日、 心エコーにより動脈管開存、三尖弁閉鎖不全を認めた。 体重も減少しはじめた。日令20日、呼吸状態が悪化し、 日令25日目に死亡した。

\section{4. 考察}

表 1 亿主なShort-Limbed Lethal Neonatal Dwarfism の鑑別診断を示した。

Dyssegmental dysplasia (Dd) は常染色体劣性遺伝 で極めて予後の悪い病気であり、レントゲン上すべての 脊椎のサイズが異なるとと、四肢が短いことなどが特長 である。

我々の症例は、妊娠中は骨盤位であること以外特別な 問題はなかったが、妊娠40週で撮った Guthmann 骨盤 計測で、下肢骨が不鮮明であった。さらに、超音波で大 腿骨長 (図 1) を精查したとてろ $2.5 \mathrm{~cm}$ で、妊娠18週程 度を示し、足が非常に短いということがわかった。出生 後は、四肢が短く、頭蓋変形があるととなどから Osteogenesis imperfecta, achondrogenesis を疑ったが、頸椎 の椎体がないとと、四肢が大変短いととより Dd と診断 された。

また、Osteogenesis imperfecta に特徵的といわれる 青色強膜は認められなかった。

\section{5. まとめ}

今回我々は、 Dd と診断した症例において、妊娠中の 超音波による検索の重要性と、Short - Limbed Lethal Neonatal Dwarfism 類似疾患の鑑別の難しさを経験し た。

\section{6. 参考文献}

1) LUISA. IZQUIERDO ORI KUSHNIR, JON AASE, P.LANTZ, TERESA CASTELLANOANDLUISB CURET: 
antenatal uetrasonic diagnons of dyssegmental dysplasia ; A Case REPORT. PRENATAL

D I AGNOS IS Vol 10. 587-592 (1990)

2) Stanley D. Handmaker, MD, John A.Campbell, MD, Lawrence D. Robinson, MD. Ogbonna

Chinwah, MD, and Robert J. Gorlin, DDS :
Dyssegmental Dwarfism: A new Syndrome of Lethal Dwarfism : Birth Defects ; Original Article Series Volume XIII, Number 3 D, pages 79-90 1977 National Foundation

表 1. Differential Diagnosis of Short-Limbed Lethal Neonatal Dwarfism

\begin{tabular}{|c|c|c|c|c|c|c|}
\hline Condition & $\begin{array}{l}\text { Fatalat } \\
\text { birth }\end{array}$ & Granial vault & Thorax & Spine & $\begin{array}{l}\text { Iliac } \\
\text { wings } \quad \text { Limbs }\end{array}$ & Genetic \\
\hline $\begin{array}{l}\text { Dyssegmental } \\
\text { dwarfism }\end{array}$ & Usually & $\begin{array}{l}\text { Small with or with- } \\
\text { out encephaloccle } \\
\text { Normal-large, } \\
\text { short base }\end{array}$ & $\begin{array}{l}\text { Moderately narrow, } \\
\text { short ribs, small } \\
\text { scapulas } \\
\text { Moderately nar- } \\
\text { row, short ribs }\end{array}$ & $\begin{array}{l}\text { Severe defectsin } \\
\text { ossification of vertebral } \\
\text { bodies with vertical } \\
\text { clefts and faulty } \\
\text { segmentation } \\
\text { Marked, uniform } \\
\text { platyspondyly; notch- } \\
\text { ing defects in upper and } \\
\text { lower surface of vertebral } \\
\text { bodies }\end{array}$ & $\begin{array}{l}\begin{array}{l}\text { Rounded, Extremely } \\
\text { short short, } \\
\text { diameters dumbbell } \\
\text { shape }\end{array} \\
\begin{array}{l}\text { Short and Very short } \\
\text { wide }\end{array}\end{array}$ & AR \\
\hline $\begin{array}{l}\text { Achondro- } \\
\text { genesis } \\
\text { Hyphophos- } \\
\text { phatasia } \\
\text { Osteogcncsis } \\
\text { imperfecta } \\
\text { congcnita }\end{array}$ & $\begin{array}{l}\text { Yes } \\
\text { In scvere } \\
\text { cascs } \\
\text { Yes }\end{array}$ & $\begin{array}{l}\text { Normal to } \\
\text { large } \\
\text { Very poorly } \\
\text { ossified; normal } \\
\text { size } \\
\text { Poorly ossified } \\
\text { invisiblc portions, } \\
\text { mosaic pattern; } \\
\text { Wormian bones }\end{array}$ & $\begin{array}{l}\text { Thin, narrow, } \\
\text { shortenedribs } \\
\text { with barrcl shape } \\
\text { Moderately narrow } \\
\text { Moderately narrow }\end{array}$ & $\begin{array}{l}\text { Unossified, nonmineralized } \\
\text { vertebral bodies } \\
\text { Many unossified spinal } \\
\text { segments; severe hypoplasia } \\
\text { with flattening } \\
\text { Slightly flattened bodies }\end{array}$ & $\begin{array}{l}\text { Poorly Very short } \\
\text { ossified and poorly } \\
\quad \text { mineralized } \\
\text { Irregular, Very short } \\
\text { poorly } \\
\text { ossified } \\
\text { Normal Very short }\end{array}$ & $\begin{array}{l}\text { AR } \\
\text { AR } \\
\text { AR }\end{array}$ \\
\hline
\end{tabular}
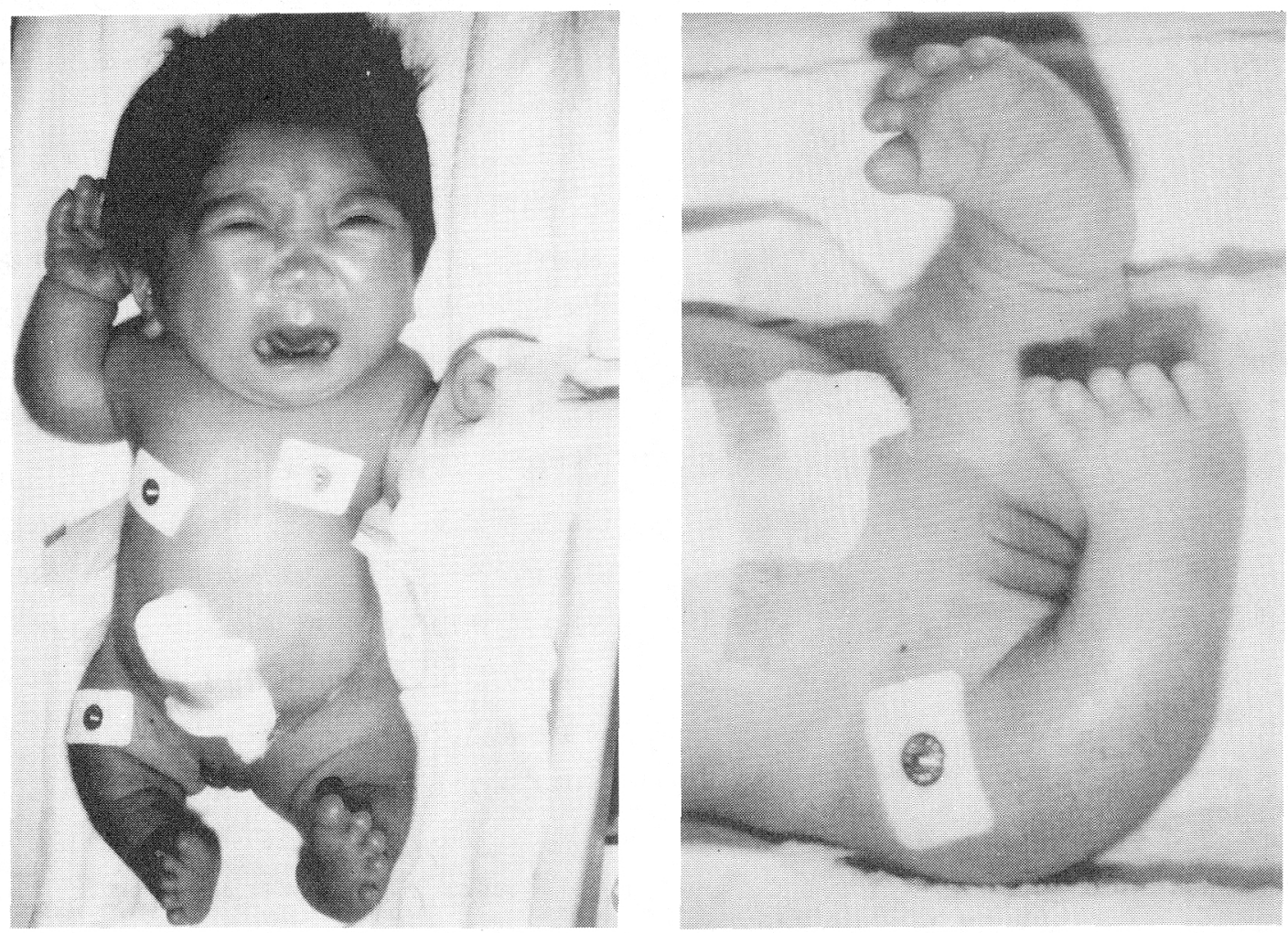
620

\section{アレルギー・自己免疫疾患・膠原病}

\section{$1 \mathrm{~J} 21$ 富山県一山村におけるスギ花粉症と地域差}

\section{O 豊田 務·山本 憲·坂下 英雄 \\ 厚生連高岡病院耳鼻咽喉科}

スギ花粉症は年々患者が増加の傾向にあり、 社会的にも注目されている疾患で、日本人一 般集団における有病率は7〜9\%と推定され ている。本来スギ花粉症の発病には遺伝要因 と環境要因の複雑な関与があるが、第一義的 要因としてスギ花粉が昭和 50 年代に至って 急激に増加したことが患者急增に直結してい る。昭和 32 年度から実施された拡大造林政 策のもとで、植林されたスギが林齢 $20 \sim 3$ O年の花粉をつけやすいスギで構成されるこ とになった。ところが昭和 40 O 50 年代に なって、日本の林業経営は急速に悪化し、現 状ではもはや衰退に近い状態にあり、この結 果スギ花粉の大量飛散と共にスギ花粉症の激 増を招くことになった。そのうえ大気污染の 改善も当分見込みなさそうで、スギ花粉症患 者も2 1 世紀に向かって確実に累積して増加 していくものと思われる。

今回我々は富山県一山村 (利賀村) におけ る住民健診の機会に地域住民のスギ花粉症を アンケート調査し、その成績を基に当院日帰 り人間ドック受診者のスギ花粉症患者の成績 を総括して、市街、農村、山村の 3 地域にお ける本症の発症頻度を検討した。調査対象者 は利賀村 124 名、当院健診センター日帰り 人間ドック 499 名の計 623 例である。利 賀村は高岡市街地より約 $50 \mathrm{Km}$ の距離にあり、 約 8 割がスギ樹木で密生する僻地山村である。 アンケート調査の内容はスライドの如く、 自覚症状として鼻症状と発症月、アレルギー 疾患についてはスギ花粉症および他のアレル
ギ一疾患の既往である。調査対象の年齢は 2 3 歳より 65 歳までの男女 124 名である （表1）。これら 124 名を各年代別、性別 に分類し、鼻症状、眼症状の有無、スギ花粉 症患者の統計を行った。先ず年代別有症状者 ( 鼻症状はあるが明らかな副鼻炎あるいはス ギ花粉飛散時期以外に症状がある) では29 歳以下に最も多く、次いで40 歳代、60歳 代となり平均 $12.9 \%$ を示す。スギ花粉症 は2 9 歳以下の男、40歳代女に多く、平均 では男性が女性より頻度が大である。スギ花 粉症患者のうちアレルギ一症状の件数は眼症 状より鼻症状のほうが強く訴えるようであり、 対象者の中には喘息、アトピー性皮膚炎の合 併症は皆無であった（表2）。

次にスギ花粉症発症の地域差を検討するた め、当院健診センタ一受診者に同様アンケー 卜調査およびR A S T を検査した。鼻症状を 有する例は市街では女に多く、農村では男に 多い傾向にあり、全体として農村より市街に 有症状者が多くみられた。また $3 \cdot 4$ 月の季 節性鼻アレルギー(スギ花粉症とした) は市 街の症例に多くみられた（表3）。ちなみに 健診センター受診者499名のスギRAST を施行しその陽性率を比較すると、アンケー 卜調査の結果と同様に市街の症例に陽性率が 高かった（表 4) 。利賀村および健診センタ 一のアンケート調査を総合して市街、農村、 山村におけるスギ花粉症の発症頻度を比較し た（表 5)。市街19.0\%と最も多く、次 いで山村、農苻心順と梞った。きた 
境として 2 群を比較すると市街では 50 歳以 上の女に多く、農村、山村では 50 歳未満の 男に多い傾向にあった。

\section{考察}

スギ花粉症の発症要因には遺伝的素因が関 与することは勿論であるが、環境要因として 現在注目されている大気污染が重要な一因と 考えられる。過去 12 年間の大気污染物質と スギ花粉症患者の増減との相関を求めた。結 果はメタンおよび全炭化水素にやや相関を示 した。このディーゼル排出微粒子（diesel exhaust particulate D E P ) の主成分は 活性炭と同じ炭素の微粒子で、この活性炭が アジュバント効果をもつことが知られており、 結果的には市街の症例にスギ花粉症患者が多
いと推察された。また各地域における性別発 症頻度では市街に女が多く、農村、山村に男 が多い傾向にあった。原因は定かではないが、 市街では男は家屋内で、農村、山村は家屋外 での作業が多く、従ってスギ花粉に暴露され る時間的差によるものかも知れない。

$$
\text { まと め }
$$

（1）山村利賀村におけるスギ花粉症患者は 9. $7 \%$ にみられ、30歳未満、40 歳代の 順に患者頻度が高い

（2）健診センターにおけるスギ花粉症患者 は市街の女、男の順に多い

（3）地域別には市街、山村、農村の順にス ギ花粉症が多く、市街では女、農村、山村で は男に多い傾向にあった。
利賀村花粉症アンケート(表 1)

\begin{tabular}{|c|c|c|c|c|c|c|c|c|c|}
\hline 年 齢 & \multicolumn{3}{|c|}{$\sigma^{7}$} & \multicolumn{3}{|c|}{ 9 } & \multicolumn{3}{|c|}{ 合 } \\
\cline { 2 - 9 } & 例数 & 有症\% & 花粉\% & 例数 & 有症\% & 花粉\% & 例数 & 有症\% & 花粉\% \\
\hline $29 \downarrow$ & 11 & 4 & 4 & 5 & 1 & 0 & 16 & 5 & 4 \\
& & $(36.4)$ & $(36.4)$ & & $(20.0)$ & $(0.0)$ & & $(31.3)$ & $(25.0)$ \\
\hline 30 代 & 12 & 1 & 1 & 8 & 0 & 0 & 20 & 1 & 1 \\
& & $(8.3)$ & $(8.3)$ & & $(0.0)$ & $(0.0)$ & & $(5.0)$ & $(5.0)$ \\
\hline 40 代 & 24 & 4 & 3 & 10 & 1 & 2 & 34 & 5 & 5 \\
& & $(16.7)$ & $(12.5)$ & & $(10.0)$ & $(20.0)$ & & $(14.7)$ & $(14.7)$ \\
\hline 50 代 & 22 & 2 & 1 & 25 & 2 & 1 & 47 & 4 & 2 \\
& & $(9.1)$ & $(4.5)$ & & $(8.0)$ & $(4.0)$ & & $(8.5)$ & $(4.3)$ \\
\hline 601 & 3 & 0 & 0 & 4 & 1 & 0 & 7 & 1 & 0 \\
& & $(0.0)$ & $(0.0)$ & & $(25.0)$ & $(0.0)$ & & $(14.3)$ & $(0.0)$ \\
\hline 合 計 & 72 & 11 & 9 & 52 & 5 & 3 & 124 & 16 & 12 \\
& & $(15.3)$ & $(12.5)$ & & $(9.6)$ & $(5.8)$ & & $(12.9)$ & $(9.7)$ \\
\hline
\end{tabular}

健診センタ一花粉症アンケート(表3)

\begin{tabular}{|c|c|c|c|c|c|c|c|c|c|}
\hline 地域 & $\sigma^{7}$ 例 & 有症\% & 花粉\% & 古例 & 有症\% & 花粉\% & 合計 & 有症\% & 花粉\% \\
\hline 市街 & 31 & 7 & 5 & 32 & 11 & 7 & 63 & 18 & 12 \\
& & $(22.6)$ & $(16.2)$ & & $(34.4)$ & $(21.9)$ & & $(28.6)$ & $(19.0)$ \\
\hline 農村 & 208 & 39 & 16 & 216 & 27 & 20 & 424 & 66 & 36 \\
& & $(18.8)$ & $(7.7)$ & & $(12.5)$ & $(9.3)$ & & $(15.6)$ & $(8.5)$ \\
\hline 9 & 0 & 0 & 3 & 2 & 1 & 12 & 2 & 1 \\
& & $(0.0)$ & $(0.0)$ & & $(66.7)$ & $(33.3)$ & & $(16.7)$ & $(8.3)$ \\
\hline
\end{tabular}

利賀村アンケートによるアレルギ一症状(表2)

\begin{tabular}{|c|c|c|c|c|c|c|}
\hline \multicolumn{2}{|c|}{ くしやみ } & 鼻 & 閉 & 翼 & \multicolumn{2}{|c|}{ 目のかゆみ } \\
\hline$\sigma^{7}$ & 우 & $0^{7}$ & 우 & 우 & $\sigma^{7}$ & q \\
\hline 7 & 3 & 8 & 1 & 1 & 5 & 1 \\
\hline \multicolumn{2}{|c|}{10} & \multicolumn{2}{|c|}{9} & 8 & \multicolumn{2}{|c|}{$v$} \\
\hline
\end{tabular}

健診センターRAST成績(表4)

\begin{tabular}{|l|c|c|c|c|c|}
\hline 地 域 & $\sigma^{7}$ & P & 合 & RAST陽性 & 陽性率\% \\
\hline 市 街 & 31 & 32 & 6 & 9 & 14.3 \\
\hline 農 村 & 207 & 217 & 42 & 43 & 10.1 \\
\hline$山$ 村 & 9 & 3 & 1 & 1 & 8.3 \\
\hline
\end{tabular}

地域別花粉症頻度 (表 5)

\begin{tabular}{|c|c|c|c|c|}
\hline 地 域 & 症 例 & 有症 & 花粉症 & 頻度\% \\
\hline 市 街 & 63 & 18 & 12 & 19.0 \\
\hline 農 村 & 425 & 66 & 30 & 7.1 \\
\hline 山 村 & 135 & 16 & 12 & 8.9 \\
\hline 合 計 & 623 & 100 & 54 & 8.7 \\
\hline
\end{tabular}

49 歳以下と 50 歳以上の地域別頻度 (表6)

\begin{tabular}{|c|c|c|c|c|c|c|}
\hline 地域 & $49 \downarrow$ & 花粉症 & 頻度 & $50 \uparrow$ & 花粉症 & 頻度 \\
\hline 市街 & 23 & 2 & 8.7 & 40 & 10 & 25.0 \\
\hline 農村 & 163 & 20 & 14.7 & 262 & 16 & 6.1 \\
\hline$山$ 山村 & 76 & 9 & 11.8 & 59 & 4 & 6.8 \\
\hline
\end{tabular}


1J22

当院におけるヒノキ化粉我散について

\section{○西川恵子・西川益利 - 高村明子 - 上田品子 - 浜本延高}

（周東総合病院）

[はじめに ]

春の花粉症として良く知られているものに は、スギ花粉が原因のスギ花粉症がある。ス ギ花粉症の患者の中には、スギ花粉飛散の終 了後にも、花粉症症状増悪を訴える者がいる。 これらはヒノキ花粉飛散期間と症状が一致し ていることより、ヒノキ花粉が原因であるヒ ノキ花粉症が疑われる。当院では1984年 よりスギ・ヒノキ花粉飛散数の測定を行なっ ており、ここ数年ヒノキ花粉飛散数が增加傾 向にあるので報告する。

\section{[方法］}

D u r h a m型花粉採集器を設置し、ワセ リンを塗布したスライドグラスを固定し、毎 日取り替えて、スライドグラスに落下付着し た花粉数を測定した。

\section{[結果]}

1993 年のスギ・ヒノキ花粉飛散期間に おける、毎日のスギ・ヒノキ花粉飛散数は図 1 の如くで、まずスギ花粉飛散が始まり、ス スギ花粉飛散が終わりに近付くと、ヒノキ花 粉飛散が始まった。

しかし年度別では、1989年まではスギ 花粉飛散に比して、ヒノキ花粉飛散は少なく、 スギ・ヒノキ花粉飛散総数に比して、ヒノキ 花粉飛散総数は $3 \%$ 以下であった。ところが 1990 年よりヒノキ花粉飛散数は増加傾向 を認め、1993年のヒノキ花粉飛散総数は 1200 個 $/ \mathrm{c} \mathrm{m}^{2}$ とスギ・ヒノキ花粉飛散 総数の $23 \%$ 占めるに至った（図2）。

\section{[考察]}

山口県林業統計要覧によると、1985年 まではスギ森林面積（民有林）は、ヒノキ森 林面積（民有林）を上回っていた。しかし造 林実績は、毎年ヒノキ森林面積はスギ森林面 積の 5 〜 倍であり、1986 年以降では、 ヒノキ森林面積がスギ森林面積を上回ってき た。しかも年々ヒノキ森林面積が増える傾向 にある（図 3 ）。つまり最近のヒノキ花粉飛 散数増加の原因は、ヒノキ森林面積の増加に よるものと思われる。

従来春の花粉症の原因としてのスギ花粉は その飛散数の増減で、その年の花粉症の症状 の軽重、あるいはその年の花粉症患者数の増 減に影響してきた。しかしヒノキ花粉はスギ 花粉と共通抗原性を有するとされており、ヒ ノキ花粉の飛散数増加が、春の花粉症の症状 および患者数の変動の一因となることが予想 される。

今後もスギだけでなくヒノキ花粉飛散数の 動向に注目したい。 


\section{3年スギ・ヒノキ花粉飛散状況と天気}

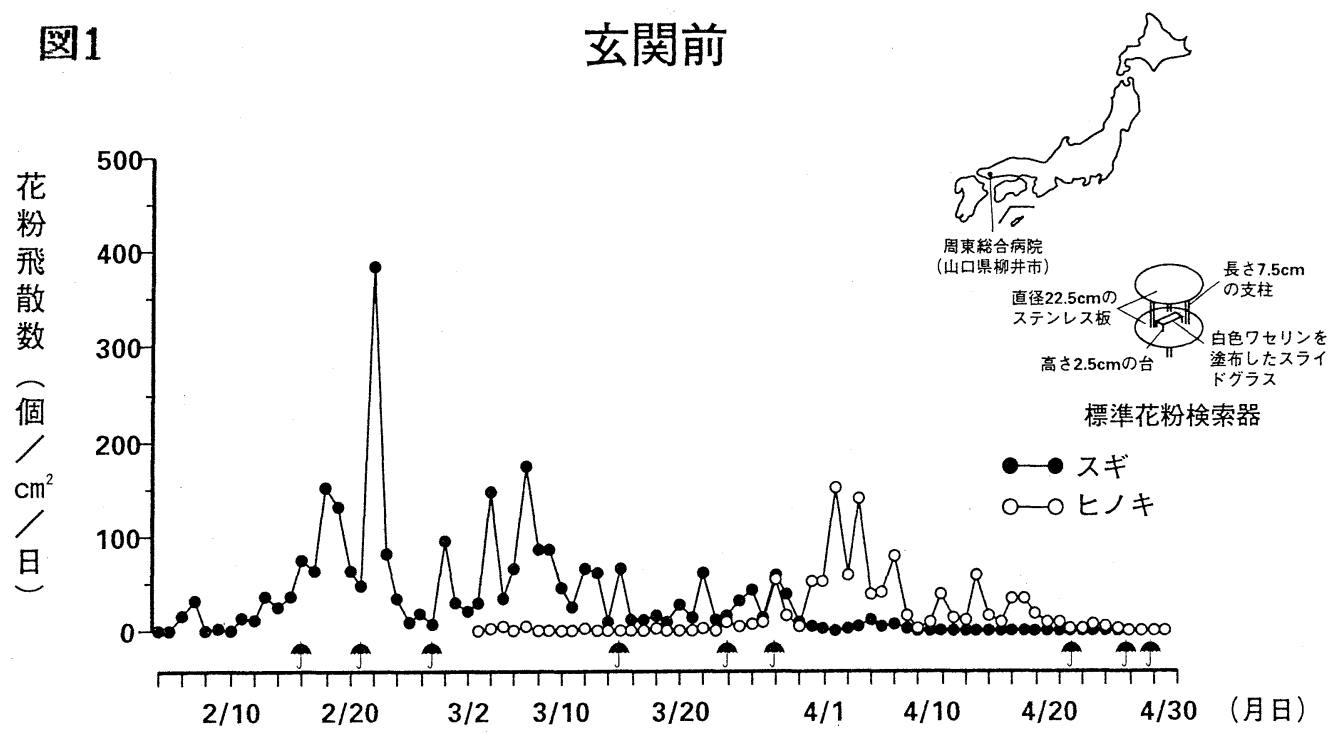

図2

個/ $\mathrm{cm} 2$

5000

$4000-3470$

3000

2000

1000

0

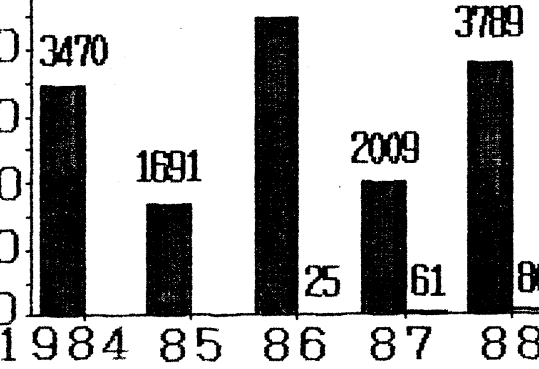

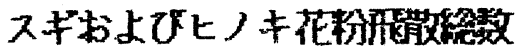

4924 